MARCO ANTONIO DOS ANJOS

\title{
O HUMOR: ESTUDO À LUZ DO DIREITO DE AUTOR E DA PERSONALIDADE
}

UNIVERSIDADE DE SÃO PAULO

SÃO PAULO 


\section{MARCO ANTONIO DOS ANJOS}

\section{O HUMOR: ESTUDO À LUZ DO DIREITO DE AUTOR E DA PERSONALIDADE}

Tese apresentada à banca examinadora da Faculdade de Direito da Universidade de São Paulo, para obtenção do título de Doutor em Direito (Área de Concentração: Direito Civil).

Orientadora: Professora Associada Silmara Juny de Abreu Chinelato

Universidade de São Paulo

São Paulo 
Marco Antonio dos Anjos

\section{O HUMOR: ESTUDO À LUZ DO DIREITO DE AUTOR E DA PERSONALIDADE}

Faculdade de Direito da Universidade de São Paulo

São Paulo 


\section{SUMÁRIO}

Introdução.

Parte 1 - O HUMOR.

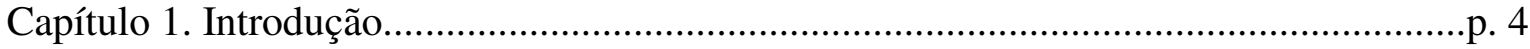

Seção I. Significado de humor........................................................................... 4

Seção II. Principais manifestações............................................................................ 7

$\S 1^{\mathrm{o}}$ Paródia.............................................................................................. 7

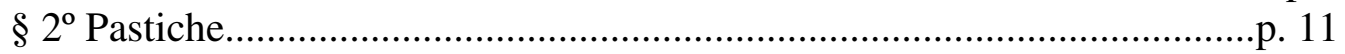

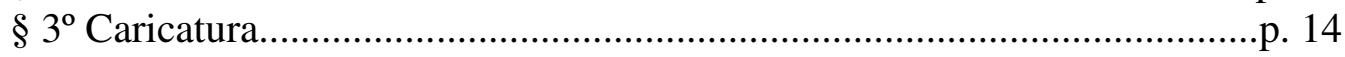

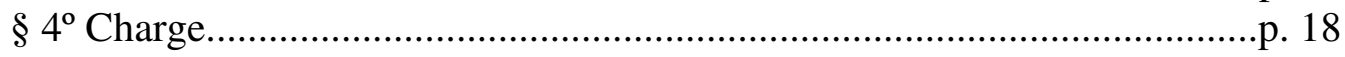

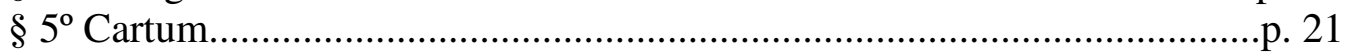

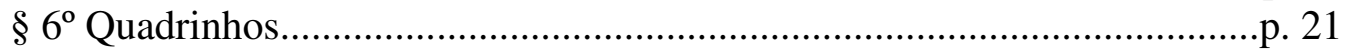

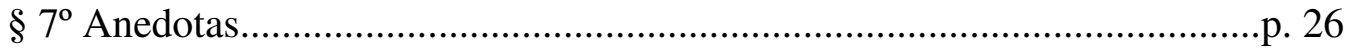

Capítulo 2. O humor e sua relevância para outros ramos do conhecimento....................p. 29

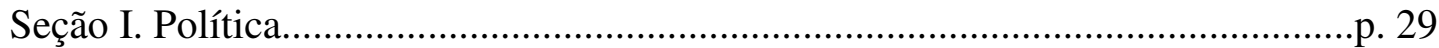

Seção II. Medicina............................................................................................ 36

Parte 2 - O HUMOR E SUA RELEVÂNCIA PARA O DIREITO................................p. 39

Capítulo 1. Os direitos autorais e os direitos da personalidade......................................p. 39

Seção I. Direito de autor............................................................................................ 39

Seção II. Direitos da personalidade........................................................................ 40

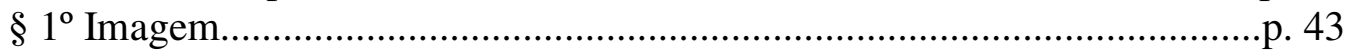

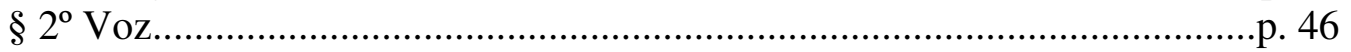

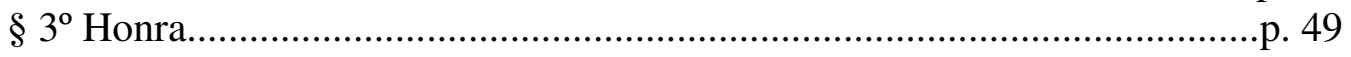

Capítulo 2. As principais manifestações humorísticas e suas implicações jurídicas.......p. 50

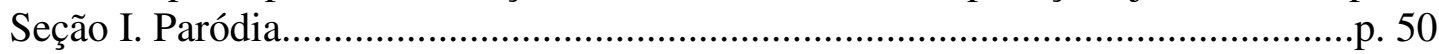

$\S 1^{\circ}$ Requisitos legais........................................................................p. 56

A) imitação da obra primígena.............................................................. 56

B) não provocar descrédito à obra originária....................................... 59

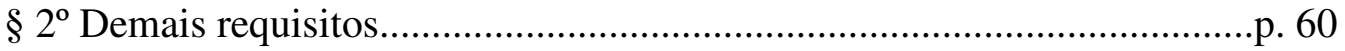

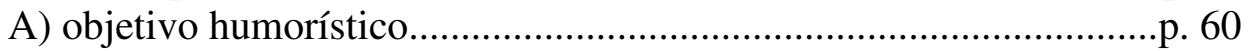

B) inconfundibilidade com a obra parodiada......................................p. 63

C) ausência de prejuízo ao autor parodiado........................................p. 65

D) finalidade de crítica à obra parodiada........................................p. 66

Seção II. Pastiche..........................................................................................p. 68

Seção III. Caricatura............................................................................................ 69

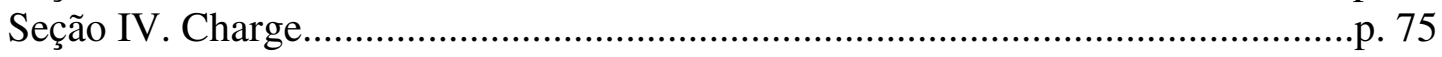

Seção V. Cartum............................................................................................... 80

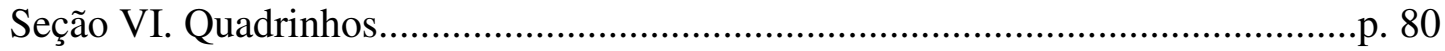




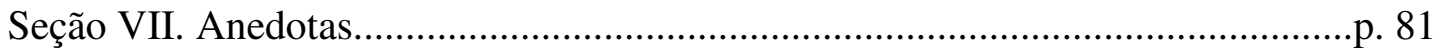

Seção VIII. Imitações cômicas.............................................................................. 84

Seção IX. Esquetes, entrevistas humorísticas e câmeras escondidas......................p. 87

Capítulo 3. O fair use e a paródia..................................................................................p. 95

Seção I. O fair use .............................................................................................p. 95

Seção II. O fair use e a paródia............................................................................ 100

Capítulo 4. Humorismo, liberdade de expressão e censura...........................................p. 103

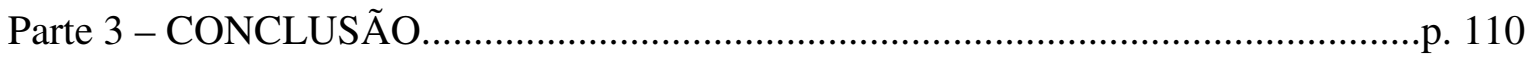

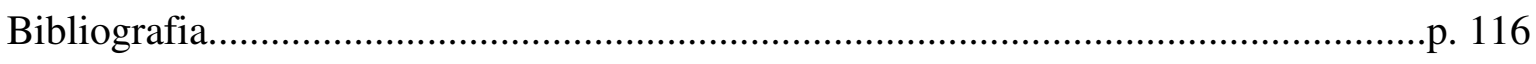

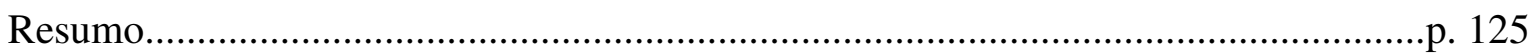

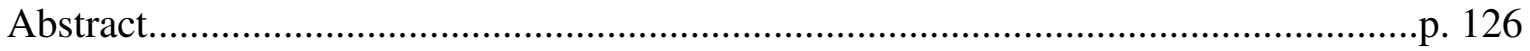

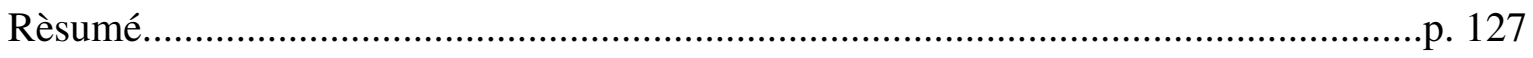




\section{INTRODUÇÃO}

A doutrina brasileira não tem dedicado às atividades humorísticas um estudo mais específico. Embora existam pesquisas no tocante ao direito à imagem e aos direitos relativos aos meios de comunicação (para os quais a análise de atividades humorísticas apresenta relevância), além de trabalhos sobre as limitações ao direito de autor, que incluem as paródias, ainda faltam estudos que tenham unicamente o humorismo como objeto de investigação à luz do direito.

Embora não se discuta que o humor, de forma geral, é algo prazeroso e benéfico ao ser humano, o abuso na criação de obras humorísticas pode gerar, e efetivamente gera, danos às pessoas tanto em seus direitos da personalidade como também em seus direitos patrimoniais.

A criação humorística, que pode se apresentar de diversas formas, como a paródia, a caricatura, a anedota, a imitação etc., dá azo a vários exemplos em que há choque entre a liberdade de expressão dos humoristas e direitos os autorais dos criadores das obras satirizadas e o direito à honra ou à imagem das pessoas ridicularizadas.

Vale destacar o caso da paródia. Segundo o artigo 47, da Lei 9.610/98, "são livres as paráfrases e paródias que não forem verdadeiras reproduções da obra originária nem lhe implicarem descrédito". A legislação não confere efetiva proteção ao autor da obra parodiada; além disso, não é exagero afirmar que, em razão de seu caráter cômico, a paródia, por si só, tem potencial para implicar descrédito ou menoscabo.

Assim, é relevante indagar se, para a efetiva proteção do autor da obra primígena e de sua criação, fruto de seu intelecto, a paródia deveria ter seus requisitos melhor indicados na legislação, ou, ao menos, pela doutrina.

Em outras atividades, como no caso dos programas humorísticos de televisão, a possibilidade do surgimento de conflitos jurídicos é significativa. As imitações de pessoas famosas podem ofender não apenas o direito à imagem dos imitados como também a sua honra. 
Também as entrevistas e outras formas de participação de pessoas em programas humorísticos de rádio e televisão podem, mesmo que autorizadas, mas sem o devido esclarecimento da forma como elas terão a imagem divulgada, ser prejudiciais. Esses programas não podem, sob o argumento de que o humorismo é livre e que não deve sofrer restrições, gerar situações danosas a direitos de autor ou de personalidade de outrem. Já houve registro de entrevistado que reagiu violentamente diante do que considerou como uma provocação e de outras personalidades que foram insistentemente perseguidas em razão de não concordarem em participar de quadros televisivos. A recusa ao convite para a participação nesses programas humorísticos costuma trazer como conseqüência a insinuação de que o convidado é arrogante.

Nota-se uma inversão de valores, pois é um direito de qualquer pessoa se recusar a dar entrevistas ou participar de situações hilárias, principalmente quando essa hilaridade vem de provocações.

Também merecem investigação as consequiências jurídicas da utilização em quadros humorísticos de atores caracterizados ou sósias de pessoas, fazendo-se brincadeiras e insinuações que vão desde zombarias pouco ofensivas até comentários de natureza sexual ou sobre a prática de crimes. Mostram-se excessivas essas formas de indagações e piadas, pois não se deve esquecer que no Brasil existe o princípio da presunção de inocência.

Outro exemplo pode ser citado. É discutível se a caricatura é livre, não dependendo de autorização da pessoa representada. Tal forma de desenho tem como marcante característica a deformação ou exagero de determinados atributos físicos da pessoa retratada. A deformação física é, juntamente com a situação cômica, um dos elementos básicos da representação humorística. Considerando-se que muitas vezes essa alteração exagerada mira exatamente aspectos físicos desfavoráveis da pessoa retratada, é possível que esta se sinta ofendida ou, ao menos, bastante incomodada ao ver seu rosto ou corpo deformados no desenho.

A idéia de exigir autorização da pessoa caricaturada merece ser analisada, pois pode evitar transtornos e dissabores que uma compensação por danos morais não tem meio 
para eliminar. Torna-se, para isso, muito importante um melhor conhecimento sobre a distinção entre caricatura e charge, cujos conceitos são comumente confundidos tanto na doutrina como na jurisprudência.

Também merecem destaque as imitações humorísticas de obras clássicas de todas as áreas, inclusive as infantis. Essas paródias muitas vezes são criativas e são manifestações de um relevante direito de crítica. Porém, essas obras cômicas às vezes ingressam na seara do riso fácil ou do apelo à sensualidade exagerada, transformando-se em verdadeiras desfigurações das obras primígenas e seus personagens.

O humor, mesmo sendo algo apreciado na humanidade, pode ficar acima dos direitos de autor e da personalidade das pessoas por ele atingidas? É aceitável a busca, a qualquer preço, do riso?

Em tempos como os atuais, em que a vida é difícil e repleta de percalços, é natural que cada vez mais se procurem momentos de descontração. Porém, o lazer e o riso de uma pessoa não devem ser alcançados às custas dos direitos de outra.

A Tese procurará mostrar que é importante a busca de um ponto de equilíbrio entre o humorismo e o direito de autor e da personalidade, admitindo-se que, embora aquele seja importante para as pessoas, estes não devem ser deixados de lado sem que exista um fundamento plausível. 


\title{
PARTE 1 - O HUMOR
}

\section{CAPÍTULO 1. INTRODUÇÃO}

\author{
Seção I. Significado de humor
}

A palavra humor tem vários significados, conforme indica o Dicionário AURÉLIO:

1. Fisiol. Substância orgânica líquida ou semilíquida. 2. Anat. Designação comum a certas matérias liquidas existentes no organismo.

3. Umidade (1): "Sentiam-se na brisa h u m o r e s marítimos." (José Lins do Rego, Gregos e Troianos, p. 131.) 4. Disposição de espírito: Dependendo de seu h u m o r, irá ou não conosco ao passeio; Está de mau h u m o r. 5. Veia cômica; graça, espírito: Todos riem de suas histórias: conta-as sempre com muito h u m o r. 6. Capacidade de perceber, apreciar ou expressar o que é cômico ou divertido. (...). ${ }^{1}$

Significados semelhantes são elencados pelo Dicionário HOUAISS ${ }^{2}$.

Jan Bremmer e Herman Roodenburg entendem o humor como "qualquer mensagem - expressa por atos, palavras, escritos, imagens ou músicas - cuja intenção é a de provocar o riso ou um sorriso",3.

A definição apresentada, ao mencionar que a intenção é de provocar "riso" ou "sorriso", deixa implícito que há diferença entre esses dois termos. Os Dicionários

\footnotetext{
${ }^{1}$ FERREIRA, Aurélio Buarque de Holanda. Novo dicionário da língua portuguesa, p. 909.

2 “....) 1 HIST. MED líquido secretado pelo corpo e que era tido como determinante das condições físicas e mentais do indivíduo [ $\mathrm{Na}$ Antigüidade Clássica contavam-se quatro humores: sangue, bile amarela, fleuma ou pituíta e bile negra ou atrabílis.] 2 p.ext. ANAT designação comum a substâncias líquidas existentes no corpo 3 MED estado afetivo durável que depende da constituição psicofisiológica do organismo como um todo, constituindo o pano de fundo sobre o qual diferentes conteúdos psíquicos tomam uma tonalidade afetiva, p. ex., de irritabilidade, impassibilidade, tristeza etc., que ultrapassa sua ação imediata 4 (1665) p. ext. estado de espírito ou de ânimo; disposição, temperamento <a realização do passeio vai depender do $h$. de seu pai> <anda com um péssimo h.> 5 p. ext. comicidade em geral; graça, jocosidade $\mathbf{6}$ expressão irônica e engenhosamente elaborada da realidade; espírito $<\mathrm{o} \mathrm{h}$. catártico da chanchada $>7 \mathrm{p}$. mer. Faculdade de perceber ou expressar tal comicidade <h. histriônico>". (HOUAISS, Antônio; VILLAR, Mauro de Salles. Dicionário Houaiss da língua portuguesa, p. 1555).

${ }^{3}$ BREMMER, Jan: ROODENBURG, Herman. Introdução: humor e história, p. 13.
} 
AURÉLIO e HOUAISS mostram que ambos são expressões de alegria, mas que o sorriso é uma forma mais branda de riso, um riso mais discreto e contido ${ }^{4}$.

\footnotetext{
${ }^{4}$ De acordo com AURÉLIO (Novo dicionário da língua portuguesa), tem-se a seguinte definição: "rir. [Do lat. ridere.] $V$. int. e $p$. 1. contrair os músculos da face em consequiência de impressão alegre ou cômica; manifestar-se pelo riso: A platéia $r$ i u durante todo o espetáculo; $R i$ u - s e com a piada. 2. Mostrar-se alegre; demonstrar alegria: Todos riram satisfeitos com os resultados; $R i u-s$ e, vitorioso. 3. Ter um ar alegre, agradável; causar alegria; sorrir: $R$ i a toda a natureza em flor; A paisagem, banhada de sol, $r$ i a $-s$ e. 4. Gracejar, zombar, motejar: $R$ i a $m$ as crianças, ignorando a loucura do homem; $O$ auditório $r$ i u $-s e$ ao ouvir tantas afirmações tolas. T. i. 5. tratar algum assunto, sem seriedade, por gracejo; gracejar. 6. Revelar-se; mostrar-se (sentimento de satisfação, de alegria): "O prazer $\mathrm{r}$ i a na boca de todos." (Rebelo da Silva, Contos e Lendas, p. 172) 7. Mostrar agrado ou favor, por meio de riso ou sorriso. 8. Parecer risonho; ter um ar alegre, agradável; sorrir: A bela paisagem do vale $r$ i a para os viajantes. 9. Escarnecer, zombar, troçar: Todos $r$ i $r$ a $m$ de sua presunção. T. d. 10. Dar, emitir (riso): " $\mathrm{r}$ i a m doidinhas à socapa os jmais tentadores risos que sabiam" (Antônio Feliciano de Castilho, Amor e Melancolia, p. 249); "aqueles mesmos homens que o miravam comruim catadura chegariam até ele $\mathrm{r}$ i n d o risos francos" (Vinícius de Morais, Para Viver Um Grande Amor, p. 83); "E o mar põe-se a r i r gargalhadas de espuma." (Hermes-Fontes, Gênese, p. 63). 11. Mostrar, deixar ver, ao rir: "No meio da roda, uma negrinha talvez de dez anos, espevitada, $\mathrm{r}$ i a os dentes muito brancos." (João Alphonsus, Totônio Pacheco, p. 16). 12. P. us. Mofar, motejar, escarnecer, zombar de: Os ignorantes $r$ i e $m$ dos costumes de outros povos. (...)" (p. 1512). Já a palavra sorrir apresenta os seguintes significados: "sorrir. [Do lat. subridere.] V. int. e $p$. 1. Rir sem ruído; rir de leve, apenas com uma ligeira contração dos músculos faciais: ["O caboclo não ri, s o r r i apenas" (Inglês de Sousa, Contos Amazônicos, p. 7); "As damas ... s o r r i a m - s e para os gentis campeadores, e seus olhos cheios de luz e de promessas estimulavam até os mais tímidos." (Rebelo da Silva, Contos e Lendas, p. 175). 2. Mostrar-se alegre; alegrar-se: $S$ o $r$ r i u consigo mesmo ao relembrar os fatos. T. i. 3. Prazer, aprazer, agradar: "Pedro seria médico, Paulo advogado; tal foi a primeira escolha das profissões. ... A marinha s o r $\mathrm{r}$ i a à mãe, pela distinção particular da escola." (Machado de Assis, Esaú e Jacó, p. 29); S o r r i a-l h e a beleza sadia do campo. 4. Dar esperanças; mostrar-se prometedor: A idéia s o r $r$ i $u-l$ h e, pois parecia exeqüível. 5. Ser favorável; favorecer: A sorte s o r r i u a meu amigo. 6. Ser objeto de desejo; ser cobiçado, apetecido: $S$ o $r$ r $i$ - l h e o cargo de ministro. 7. Troçar, zombar, mofar: $S$ o $r$ r i u da ingenuidade do rapaz. T. $d$. e $i$. 8. Significar de modo risonho; exprimir agradavelmente: $S$ o $r$ r $i$ u ao companheiro o encantamento de que estava possuído. 9. Dar, esboçar (sorrisos): S o r r i u ao namorado o mais belo de seus sorrisos. T. $d$. 10. Dar, esboçar (sorriso): So r r i um sorriso de satisfação: "Minervino ficou sorrindo um sorriso triste" (Nélson de Faria, Tiziu e Outras Estórias, p. 144) (...)" (p. 1614). Já HOUAISS (Dicionário Houaiss da língua portuguesa) apresenta as seguintes definições: "rir v.(sXIII cf.FichIVPM) 1 t.i.int. e pron. contrair, em geral de modo súbito, os músculos faciais, em conseqüência de uma impressão alegre ou cômica; achar graça em <riu das histórias que o avô contou $><$ peça que faz $r$. $><$ r. $(-$ se) de um dito picante $>2$ int. assumir expressão alegre, feliz, ger. esboçando um sorriso de alegria, manifestar fisionomicamente satisfação, prazer, sorrir <está feliz, vive rindo $><$ apaixonados, seus olhos riam $>\mathbf{3}$ t.d. dar, emitir (certo tipo de riso) $<$ r. um riso provocador $><$. um riso amarelo $>4$ t.i. tratar sem seriedade (alguém ou algo determinado), utilizando palavras ou ditos espirituosos ou engraçados que manifestam humor, malícia, troça; fazer pouco caso, galhofa de; troçar, caçoar <os colegas riram da gafe que cometeu> $\mathbf{5}$ t.i.int. e pron. tratar ou considerar (alguém ou algo determinado) com desdém, escárnio, menosprezo; ridicularizar, zombar <diante de tal petulância, o remédio é r. $><$ r.(-se) de sua arrogância $\mathbf{6}$ int. e pron. p.metf. (da acp. 2) mostrar-se alegre, aprazível, agradável (falando de paisagem, natureza etc); sorrir <na fazenda, distante da cidade, as manhãs riam(-se)> 7 int. soltar a voz (falando de certos animais) (...)" (p. 2461); "sorrir $v$. (sXIV cf. FichIVPM) 1 t.d.int. e pron. dar sorriso, rir sem fazer ruído e executando somente ligeira contração muscular da boca e dos olhos; rir(-se) <sorriu o seu melhor sorriso $><a o$ vê-lo s.(-se) ela também sorriu $>2$ int. e pron. mostrar-se desvanecido e contente; alegrar-se, $\operatorname{rir}(-\mathrm{se})<s$. $(-$ se) de contentamento $>\mathbf{3}$ t.i.bit. dar, dirigir um sorriso para acalmar, encorajar, saudar etc. (alguém) $<$ contente, sorriu à noiva $><$ sorriu à irmã um sorriso de ternura $>4$ int. e pron.p.ext. mostrar a expressão que acompanha o riso <seus olhos sorriam(-se) com malícia $>\mathbf{5}$ int.e pron.fig. transparecer de modo alegre, feliz <em seus olhos sorria(-se) a infância $>\mathbf{6}$ t.i.fig. causar sensação boa; agradar, aprazer <estava feliz, a quietude campestre sorria-lhe $>7$ t.i.fig. apresentar-se de modo promissor <uma oportunidade sorriu-lhe finalmente $>\mathbf{8}$ t.i.fig. ser favorável a (alguém); contemplar $<a$ fortuna não me sorri $>9$ t.i.fig. ser objeto de desejo, ser apetecido, cobiçado <o cargo de diretor sorria-lhe $>$ 10 t.i.fig. zombar de (algo); troçar, mofar, rir <s. da desgraça alheia $>\mathbf{1 1}$ bit.fig. mostrar (algo) de modo alegre ou agradável <procurou s.-lhe toda a alegria que vinha sentindo $>$ (...)" (p. 2612).
} 
É muito difícil, para não dizer impossível, uma definição exata do que seria humor. Depende muito do contexto: o que o que para uma pessoa é humor, para outra é uma ofensa, ou, então, o que para um grupo social é técnica aceitável para fazer graça, para outro é prática inadmissível. Ademais, o humor é extremamente variável, não seguindo padrões universais, e pode depender de informações prévias para que seja compreendido. Nota-se, portanto, que ele tem um forte caráter social, variando conforme usos e costumes de cada localidade ou de determinado grupo social. É nesse sentido, por exemplo, que se fala em "humor inglês", que não produzirá efeitos risíveis em outros países, dada a diferença cultural e de comportamento. Nesse sentido, Henri Bergson conclui que "nosso riso é sempre o riso de um grupo" ${ }^{\circ}$.

Deve ser considerada também a circunstância de que o riso e o sorriso são inerentes ao ser humano, que o manifestam desde a infância, sendo que o sorriso é manifestado ainda quando bebê ${ }^{6}$. Além de o indivíduo humano ser o único animal que ri, Henri Bergson estende essa idéia para incluir que é somente o ser humano quem faz rir. Tudo que é risível de alguma forma tem relação com o humano ${ }^{7}$.

Também deve ser lembrada a hipótese em que uma pessoa, por estar nervosa ou até mesmo descontrolada, passa a rir. Esse comportamento involuntário certamente não se refere a uma situação cômica.

\footnotetext{
${ }^{5}$ Logo em seguida a essa afirmação, o autor a esclarece com exemplos. Diz ele: "Ao leitor talvez já tenha ocorrido ouvir, em viagem de trem ou à mesa de hospedarias, histórias que deviam ser cômicas para os viajantes que as contavam, pois que os faziam rir com muito gosto. O leitor teria rido como eles se pertencesse à sociedade deles. Mas, não pertencendo, não tinha vontade alguma de rir. Um homem, a quem perguntaram por que não chorava num sermão em que todos derramavam muitas lágrimas, respondeu: 'Não sou desta paróquia"”. (O riso: ensaio sobre a significância da comicidade, p. 5).

${ }^{6}$ Benjamin James Sadock e Virginia Alcott Sadock informam que o bebê apresenta duas fases de sorriso: a endógena e a exógena. A primeira ocorre durante os dois primeiros meses de vida da criança e é espontânea, sem relação com estímulos externos que tenha recebido; já a segunda, se dá em resposta a estímulos externos, geralmente feitos pela mãe. (Compêndio de psiquiatria: ciências do comportamento e psiquiatria clínica, $\mathrm{p}$. 42).

De acordo com ensinamentos da Enciclopédia Britânica, no verbete "Emotion", o sorriso e o riso são expressões de emoção. O sorriso já pode ser encontrado em bebês, nas suas primeiras semanas de vida, o que sugere que a capacidade para se fazer movimentos faciais básicos de expressão são inatos. Porém, com relação ao riso, ele não surge até depois da $20^{\mathrm{a}}$ semana de vida da criança, sendo que no primeiro ano é considerado forma reflexa de comportamento. (Encyclopadia Britannica, v. 8, p. 338-339).

${ }^{7}$ Henri Bergson ensina que "Não há comicidade fora daquilo que é propriamente humano. Uma paisagem poderá ser bela, graciosa, sublime, insignificante ou feia; nunca será risível. Rimos de um animal, mas por termos surpreendido nele uma atitude humana ou uma expressão humana. Rimos de um chapéu; mas então não estamos gracejando com o pedaço de feltro ou de palha, mas com a forma que os homens lhe deram, com o capricho humano que lhe serviu de molde". ( $O$ riso: ensaio sobre a significação da comicidade, p. 2-3).
} 
Explicar aquilo cujo sentido é conhecido desde sempre parece ser algo pouco proveitoso, sendo mais útil um enfoque da importância e características do humor, sem a busca por uma descrição precisa. Dessa forma, opta-se por não buscar o conceito exato de humor, acompanhando o ensinamento de Jonathan Pollock que explica que "toda definição de humor decepciona mas é possível aprender a reconhecê-lo", ${ }^{9}$

A esfera de estudo nesta pesquisa não abrange o resultado humorístico, se este foi atingido ou não, mas, sim, a atividade humorística naquilo que possa colidir com direitos de autor ou da personalidade. Tem mais importância, assim, o humor como meio, e não como resultado, já que este é incerto, eis que depende de como o destinatário interpretará o que lhe foi mostrado.

As palavras "humor" e "humorístico" serão usadas no texto juntamente com outros vocábulos que, embora merecedores de estudos mais específicos para a investigação de seu alcance, também têm o genérico sentido de algo que leva ao riso, como as palavras "cômico", "satírico", "engraçado" e "jocoso".

Seção II. Principais manifestações

$\S 1^{\circ}$ Paródia

A palavra paródia vem do grego para- ode, que significa um canto paralelo a outro. O dicionário AURÉLIO a registra da seguinte forma:

paródia. [Do gr. parodía, 'canto ao lado de outro', pelo lat. parodia.] S. f. 1. Imitação cômica de uma composição literária. 2. P. ext. Imitação burlesca. 3. Teat. Comédia satírica ou farsa em que se ridiculariza uma obra trágica ou dramática; arremedo. [Cf. parodia, do v. parodiar]. ${ }^{10}$

\footnotetext{
${ }^{8}$ POLLOCK, Jonathan. Qué es el humor?, p. 111.

${ }^{9}$ Será, pois, utilizado o mesmo critério adotado por Jota Rui em seu livro A alegre história do humor no Brasil. Na página 9 da obra ele explica que "deu-se à palavra humor o sentido mais amplo que o idioma permite e que abrange tudo quanto pode ser dito, escrito ou praticado com a intenção de fazer rir, sorrir ou apenas divertir mentalmente. Evitaram-se teorias e classificações complicadas que não resistem ao tempo e tornam ainda mais incompreensível o que já é difícil de ser compreendido com simplicidade...".

${ }^{10}$ FERREIRA, Aurélio Buarque de Holanda. Novo dicionário Aurélio da língua portuguesa, p. 1272.
} 
Um pouco diversos são os significados apresentados por HOUAISS, já que acrescenta a idéia de imitação dos procedimentos de uma corrente artística ou de uma escola $^{11}$.

No sentido literário a paródia “designa toda composição literária que imita, cômica ou satiricamente, o tema ou/e a forma de uma obra séria. $\mathrm{O}$ intuito da paródia consiste em ridicularizar uma tendência ou um estilo que, por qualquer motivo, se torna conhecido e dominante" $" 12$.

A partir dessas definições, podemos inferir que a palavra paródia pode ser entendida de duas formas: como uma imitação total ou parcial, de forma humorística, de uma obra específica ou como imitação de todo um gênero ou estilo.

Affonso Romano de Sant ${ }^{\prime}$ Anna ensina que o vocábulo estava inicialmente ligado à música, eis que a ode era um poema para ser cantado. Assim, na paródia, um poema era contracanto de outro. Mais modernamente, na literatura, ela tem relação com a técnica da intertextualidade, que ocorre quando o texto de um autor remete a texto de outro ${ }^{13}$.

Parodiar uma criação de outro autor seria, portanto, imitá-la humoristicamente, recriando-a com originalidade e com o objetivo de fazer rir.

Esse entendimento de paródia, entretanto, não é exato, já que o caráter humorístico, embora seja o mais comum na prática, não é elemento essencial dessa forma de criação. A paródia, na realidade, é a negação de um texto, sua antítese. Assim, é perfeitamente aceitável que se parodie um texto dramático recriando-o para a forma cômica; porém, é viável, também, fazer o contrário, ou seja, conferir formato dramático a uma obra humorística.

\footnotetext{
${ }^{11}$ Antônio Houaiss e Mauro de Salles Villar, em sua obra Dicionário Houaiss da língua portuguesa, p. 2137, entendem por paródia a "obra literária, teatral, musical etc. que imita outra obra, ou os procedimentos de uma corrente artística, escola etc. com objetivo jocoso ou satírico; arremedo ...".

${ }^{12}$ MOISÉS, Massaud. Dicionário de termos literários, p. 388.

${ }^{13}$ SANT'ANNA, Affonso Romano de. Paródia, paráfrase \& cia, p. 12-13.
} 
O que interessa para tipificar essa técnica é a recriação, o ato de transportar uma obra para outra, que a imita mas, de certa forma, a nega. Toda vez que isso ocorrer, haverá paródia.

Logo, da mesma forma que é possível, por exemplo, parodiar a obra Os sertões, de Euclides da Cunha, transformando-a em criação humorística, também é possível fazê-lo em um universo futurista, como ficção científica, mesmo que, neste caso, não exista intenção de obtenção de um resultado cômico.

A idéia de subversão de uma obra, negando-a, é o ponto central da paródia. O fato de isso ser muito mais freqüente por meio da transformação de uma criação dramática em humorística não impede outras formas de obras antitéticas, porém em gêneros distintos da comicidade.

A paródia é admitida como uma criação nova, distinta da parodiada, porque naquela o autor se afasta do trabalho anterior, que é usado como ponto de partida para uma nova atividade intelectiva e criativa. Na paródia, há uma negação do texto anterior, que é alterado, até mesmo deturpado, com o objetivo de crítica e inovação. Esse objetivo não precisa se revelar sutil ou conter grandes indagações, podendo se manifestar tão só pela deturpação da obra parodiada, que é mostrada de forma oposta à anteriormente concebida.

Não se retoma o texto anterior, mas, sim, provoca-se um contraste com o que foi anteriormente escrito. Dessa forma, o autor da obra parodiada é desvinculado da paródia, ou seja, não está ligado a ela, não está "responsabilizado" pelo que é feito na criação posterior.

É nisso que reside a principal diferença com a paráfrase, pois, nesta, o autor confirma o texto parafraseado, reescrevendo-o de forma distinta, porém mantendo o que foi dito na primeira criação. Não há uma antítese, uma negação da obra anterior, mas, sim, a confirmação dessa obra.

Embora se admita que a paródia não é necessariamente a recriação humorística de uma obra, pois é possível a transformação para outra modalidade, como, por exemplo, um 
romance de amor ser alterado para a forma de romance de terror, é mister reconhecer que é bem mais comum a paródia com um sentido anedótico.

Assim, a criação humorística tornou-se campo fértil para a feitura de paródias, eis que a idéia de alteração radical do formato da obra anterior fica mais evidente quando está presente a comicidade.

Como exemplo desse tipo de criação, Juan Carlos Pueo ${ }^{14}$ cita o filme Sonhos de um sedutor (de 1972, com direção de Herbert Ross) no qual Woody Allen, que é o autor do roteiro, interpreta um atrapalhado crítico de cinema recém-abandonado pela esposa e que gostaria de se relacionar melhor com as mulheres. Desejoso de viver um grande amor, o personagem de Woody Allen, que assiste freqüentemente ao filme Casablanca (de 1942, dirigido por Michael Curtiz), em seus devaneios, conversa com a imagem do ator Humphrey Bogart, que lhe dá conselhos. Trata-se de uma paródia de Casablanca, cujo conhecidíssimo final, ambientado em um aeroporto, é reproduzido na paródia com a mesma atmosfera e com a repetição de uma famosa fala contida na obra parodiada, porém em outro contexto. O próprio título original da película, Play it again, Sam!, é uma indicação de que se pretende brincar com a clássica história de amor ${ }^{15}$.

No cinema brasileiro, uma paródia fez graça com uma obra de William Shakespeare, Romeu e Julieta. Trata-se da obra cinematográfica $O$ casamento de Romeu e Julieta (de 2004, com direção de Bruno Barreto), que narra as confusões geradas por um amor impossível, já que o namorado pertence a uma família de corintianos fanáticos e a namorada vive em uma família de palmeirenses igualmente fanáticos. Com cenário na cidade de São Paulo, Romeu, interpretado por Marco Ricca, finge ser palmeirense para poder se aproximar de Julieta, vivida por Luana Piovani. Obviamente essa situação gera hilários momentos, já que o obstáculo que pode separar o casal, se descoberta a verdade, é quase intransponível.

\footnotetext{
${ }^{14}$ PUEO, Juan Carlos. Los reflexos em juego: uma teoria de la parodia, p. 17-39.

${ }^{15}$ No final de Casablanca, o personagem de Humphrey Bogart, Rick, convence sua amada, Ilsa, vivida por Ingrid Bergman, a deixar o amor de lado e fugir para outro país acompanhando um líder da resistência a Hitler. Embora dolorosa, aquela era a melhor decisão a ser tomada. Já no caso de Sonhos de um sedutor, o personagem de Woody Allen, Allan, que acabou vivendo um romance com a esposa de um amigo, Linda, interpretada por Diane Keaton, convence sua amante a deixá-lo, não abandonando o marido. Nessa cena, a fala de Allan em Sonhos de um sedutor é igual à de Rick em Casablanca. Impressionada com a postura de Allan, Linda lhe diz que o que foi por ele dito era muito belo; então Allan responde: “- É de Casablanca, toda minha vida sonhei em dizer isso...”.
} 
Apesar de ser admitido que a técnica paródica existe desde os textos clássicos da antigüidade, vem sendo defendido que o caráter humorístico da paródia como conhecido atualmente teve como marco a obra Dom Quixote, de Miguel de Cervantes (1547-1616), na qual há clara intenção de fazer graça com as novelas de cavalaria. Nesse livro, Cervantes narra as peripécias de um homem que lê tantas novelas de cavalaria que acaba enlouquecendo, saindo pelo mundo como se estivesse em uma grande cruzada. Há um caráter humorístico que não se limita a fazer rir, mas que também procura que o leitor tenha um senso crítico sobre os riscos do exagero e do comportamento ilimitado. Pode-se dizer que em Dom Quixote é mostrado que o excesso, até mesmo em atividade tão nobre como a leitura, pode gerar consequiências danosas, pois, embora leve ao conhecimento, na obra citada acabou levando à loucura.

Deve-se realçar que, além dos seus atributos literários, Dom Quixote ganha importância porque foi escrito em uma época em que as novelas de cavalaria eram muito comuns. Assim, o autor teve comportamento "transgressor", pois ridicularizou todo um padrão de literatura daquele momento.

Embora a doutrina e a teoria literária usem o termo paródia para classificar Dom Quixote, adota-se aqui outra conceituação: pastiche.

Convém esclarecer que, neste trabalho, a idéia de paródia terá amplitude mais limitada, se restringindo à imitação total ou parcial, de forma humorística, de uma obra específica, deixando ao pastiche a idéia de imitação humorística do estilo de outro criador, de seu trabalho como um todo, ou de uma concepção estilística reinante em determinado lugar ou época.

$\S 2^{\circ}$ Pastiche

A palavra pastiche ${ }^{16}$ deriva do italiano pasticcio, que significa pasta ou massa. De acordo com a definição dada por Massaud Moisés, pastiche é "uma obra que imita

16 Este vocábulo é também encontrado com a grafia "pasticho", como ocorre no Dicionário de termos literários de Massaud Moisés (p. 389) e no Dicionário HOUAISS (p. 2146). No presente trabalho, optou-se pela palavra do texto, que está registrada no Dicionário AURÉLIO (p. 1279) e é igual à forma francesa de referência a essa modalidade literária, expressamente mencionada na legislação autoral daquele país. 
servilmente a outra, ou mistura canhestramente trechos de várias procedências. De sentido pejorativo, corresponde, até certo ponto, à paródia"17 .

Embora o pastiche esteja comumente ligado à idéia de um trabalho de má qualidade, inferior, reles, nem sempre esse entendimento corresponde à realidade. É melhor vê-lo como uma modalidade específica de expressão narrativa do que ligá-lo a uma idéia pejorativa quanto à qualidade do resultado obtido pelo autor. Assim, o pastiche deve ser compreendido como uma imitação do estilo de outro criador, de seu trabalho como um todo, ou de uma concepção estilística reinante em determinado lugar ou época. Trata-se, pois, de um fazer “à maneira de outrem”, podendo ter caráter humorístico ou não.

Em razão da possibilidade de o pastiche ser usado como expressão humorística, é grande o risco de ser ele confundido com a paródia, já que, assim como esta, é uma imitação do trabalho intelectual de outrem e que pode ter como finalidade levar ao riso. $\mathrm{O}$ conceito dessas formas de expressão, porém, não se confundem. No pastiche, a imitação se dá a um estilo de um autor ou de toda sua obra, podendo, para isso, chegar à minúcia de reprodução de um personagem criado pelo autor que se quer imitar. Também é possível que essa imitação não verse sobre um autor específico, mas, sim, sobre um determinado estilo de expressão.

Pelos motivos acima apontados se admite, neste trabalho, que o livro Dom Quixote, de Miguel de Cervantes, na realidade, não é uma paródia, mas, sim, um pastiche. Isso é dito sem nenhuma preocupação de que possa haver qualquer intenção de menosprezar a grande criação do autor espanhol. Procura-se, aqui, como sustentado anteriormente, afastar-se do conceito de pastiche como obra de má qualidade, pois o que deve caracterizar esse tipo de criação não é seu resultado estético, que é variável em quaisquer meios de expressão da criação intelectual, mas, sim, seu caráter de imitação do estilo de um autor ou de todo um gênero, e não de uma obra específica.

Logo, Dom Quixote, mostrando um anti-herói enlouquecido que parte em uma luta contra inimigos inexistentes, em uma espécie de cruzada de um homem só, faz humor e critica o gênero novelas de cavalaria, tão comum no momento histórico em que foi criado, e não uma obra em particular.

\footnotetext{
${ }^{17}$ MOISÉS, Massaud. Dicionário de termos literários, p. 389.
} 
Para explicar o pastiche, Mario Sol Muntañola esclarece que

se trata de imitar o estilo mas não de reescrever nem de transformar, nem sequer deve afastar-se da obra de referência. Imitar o estilo pressupõe escrever da mesma maneira que o outro faz, utilizando a forma de expressar-se de outro autor, utilizando elementos que, geralmente, estão fora do âmbito protetor dos direitos de autor. ${ }^{18}$

Um exemplo brasileiro é o livro O xangô de Baker Street, da autoria de Jô Soares, que se tornou um sucesso de vendas. Nessa criação literária, posteriormente transformada em filme, o autor narra a vinda de Sherlock Holmes e seu amigo Watson ao Brasil no período de Dom Pedro II. Em razão do furto de um violino Stradivarius e do assassinato de várias mulheres, o detetive inglês é convidado a conduzir as investigações. A obra tem humor refinado e várias citações históricas, não se tratando de brincadeira com alguma história específica criada por Sir Arthur Conan Doyle. Logo, não é uma paródia, mas, sim, um pastiche, pois Jô Soares, com habilidade, coloca a dupla inglesa a vivenciar experiências brasileiras, como o calor da cidade do Rio de Janeiro, a comida típica apimentada, o surgimento da bebida conhecida como caipirinha e, até mesmo, a incorporação de um espírito no sério personagem Watson.

Outro pastiche da obra de Conan Doyle, também utilizando os referidos personagens, é o filme $O$ enigma da pirâmide (de 1985, com direção de Barry Levinson), que mostra aquela que teria sido a primeira aventura de Sherlock Holmes em sua adolescência, antes mesmo de tornar-se um detetive, mas já revelando dotes intelectuais superiores. Nesse caso, vale lembrar, trata-se de obra de aventura, e não humorística.

Reafirmando o que acima foi dito, neste trabalho será compreendido o pastiche como sendo a imitação do estilo de outro criador, de seu trabalho como um todo, ou de uma concepção estilística reinante em determinado lugar ou época.

\footnotetext{
${ }^{18}$ MUNTAÑOLA, Mario Sol. El régimen jurídico de la parodia, p. 202. "Se trata de imitar el estilo pero no de reescribir ni de transformar, ni siquiera debe alejarse de la obra de referencia. Imitar el estilo presupone escribir de la misma manera que otro lo hace, utilizando la forma de expresarse de otro autor, utilizando elementos que, generalmente, están fuera del ámbito protector de los derechos de autor".
} 
Criação artística quase sempre relacionada ao humor, se pode dizer que a caricatura teve impulso na arte ocidental por meio dos irmãos Carracci, no final do século XVI, na chamada Escola de Bolonha por eles fundada ${ }^{19}$.

A palavra caricatura vem do italiano caricare, verbo que tem como significado "carregar, sobrecarregar". Pode também ter tido influência do termo italiano carattere, que significa "caráter", ou do termo espanhol cara, que significa "rosto". Ainda nesse sentido, o termo pode ter tido origem nos perfis de rostos ou caras desenhados por Leonardo da Vinci, com diferentes formas de narizes, queixos e sobrancelhas fora do comum. ${ }^{20}$

Como descreve AURÉLIO, caricatura tem os seguintes sentidos:

caricatura. (Do it. caricatura.) $S$.f. 1. Desenho que, pelo traço, pela escolha dos detalhes, acentua ou revela certos aspectos caricatos de pessoa ou fato. 2. Teat. Representação burlesca em que se arremedam ou satirizam comicamente pessoas e fatos. 3. Reprodução deformada de algo: Só consegue escrever c a $r$ i c a $t$ u $r$ a s de romance. 4. Pessoa ridícula pelo aspecto ou pelos modos. ${ }^{21}$

O Dicionário HOUAISS traz significados em muito semelhantes aos acima elencados ${ }^{22}$.

\footnotetext{
${ }^{19}$ Menciona Joaquim da Fonseca (Caricatura: a imagem gráfica do humor, p. 43-49) que a caricatura tem origens mais remotas, podendo ser citadas gravuras em ossos de animais das épocas pré-históricas. Também os egípcios da Antigüidade representavam homens como animais, de forma irônica, ou ainda em situações ridículas. Ainda, na Grécia e Roma antigas eram feitas paródias de cenas sagradas. As caricaturas podiam ser encontradas em objetos de caráter popular e uso habitual, como na cerâmica grega e nos graffiti nas paredes de casas nas cidades romanas de Herculano e Pompéia. Os gauleses também tinham caricaturas feitas em peças de cerâmica. Na Idade Média a sátira aparecia em pórticos e vitrais de catedrais e em miniaturas dos livros das horas, além de ser cantada nas canções dos trovadores. Com o Renascimento, a sátira aparece nos estudos de caráter e de expressão, como os produzidos por Leonardo da Vinci.

${ }^{20}$ FONSECA, Joaquim da. Caricatura: a imagem gráfica do humor, p. 17-18.

${ }^{21}$ FERREIRA, Aurélio Buarque de Holanda. Novo dicionário Aurélio da língua portuguesa, p. 353.

${ }^{22}$ Segundo HOUAISS (Dicionário Houaiss da língua portuguesa, p. 626), caricatura é: "1 desenho de pessoa ou de fato que, pelas deformações obtidas por um traço cheio de exageros, se apresenta como forma de expressão grotesca ou jocosa 2 fig. reprodução deformada de alguma coisa <suas obras eram c. de arte moderna> 3 fig. indivíduo de aparência ou de maneiras ridículas <julgava-se elegante, mas não passava de uma c.> 4 TEAT representação em que se figuram pessoas e se apresentam caracteres e fatos de maneira grotesca e cômica ...".
} 
Da leitura dos sentidos indicados, nota-se que o vocábulo "caricatura" pode ser empregado para diversas situações cômicas, inclusive não se limitando às artes gráficas. Antônio Chaves, por exemplo, em artigo publicado no jornal O Estado de São Paulo, em que analisou uma lide envolvendo direitos autorais de um programa de rádio no qual foram criados personagens e eram feitas imitações de vozes, admitiu a caricatura por meio sonoro $^{23}$. Já Sylvia Helena Telarolli de Almeida Leite entende que a caricatura não se limita às artes visuais, podendo também existir por meio de palavras, tanto de forma oral quanto escrita, como no cinema e teatro (verbal), romances e poemas (escrita), entre outras formas de expressão intelectual ${ }^{24}$.

É muito forte, porém, o aspecto visual dessa forma de expressão artística, marcante desde seu surgimento. Assim, como um gênero limitado ao aspecto visual de transmissão da mensagem humorística, Joaquim da Fonseca entende que

a caricatura é a representação plástica ou gráfica de uma pessoa, tipo, ação ou idéia interpretada voluntariamente de forma distorcida sob seu aspecto ridículo ou grotesco. É um desenho que, pelo traço, pela seleção criteriosa de detalhes, acentua ou revela certos aspectos ridículos de uma pessoa ou de um fato. ${ }^{25}$

Ressalte-se que, para o autor acima citado, a caricatura é um gênero do qual seriam espécies "a charge, o cartum, o desenho de humor, a tira cômica, a histórias em quadrinhos de humor, o desenho animado e a caricatura propriamente dita, isto é, a caricatura pessoal" 26 .

Edson Carlos Romualdo explica que é comum a confusão no uso de termos ligados a esse tipo de obra, já que todas as suas espécies apresentam dois traços básicos: a expressão visual e o humorismo ${ }^{27}$.

\footnotetext{
${ }^{23}$ CHAVES, Antonio. Caricatura: protegibilidade, p. 21.

${ }^{24}$ LEITE, Sylvia Helena Telarolli de Almeida. Chapéus de palha, panamás, plumas, cartolas: a caricatura na literatura paulista (1900-1920), p. 19.

${ }^{25}$ FONSECA, Joaquim da. Caricatura: a imagem gráfica do humor, p. 17.

${ }^{26}$ FONSECA, Joaquim da. Caricatura: a imagem gráfica do humor, p. 17.

${ }^{27}$ ROMUALDO, Edson Carlos. Charge jornalística: intertextualidade e polifonia: um estudo de charges da Folha de S. Paulo, p. 19.
} 
Para evitar essa dificuldade de conceituação, eis que a palavra "caricatura" pode ser utilizada em um sentido amplo, como um gênero, ou em um específico, como caricatura propriamente dita, Camilo Riani prefere a expressão "humor gráfico", do qual a caricatura é uma de suas espécies ${ }^{28}$.

Assim, parece ser melhor o entendimento mais restrito de caricatura, como sendo a reprodução, com exageros e distorções, da forma física do ser humano, podendo, com essas linhas, retratar a personalidade do caricaturado. Nesse sentido, Edson Carlos Romualdo a entende como "o desenho que exagera propositadamente as características marcantes de um indivíduo"29. Para Camilo Riani, esta modalidade de humor gráfico é um "desenho humorístico que prioriza a distorção anatômica, geralmente com ênfase no rosto e/ou em partes marcantes/diferenciadas do corpo do retratado, revelando também, implícita ou explicitamente, traços de sua personalidade" ${ }^{, 30}$.

Embora desejável, a caricatura não necessita buscar o retrato da personalidade de alguém, podendo se limitar à busca do efeito cômico. Camilo Riani reconhece que "muitas obras tecnicamente irrepreensíveis não se preocupam em trazer à tona o aspecto psicológico do caricaturado",31. Vale destacar o comentário de Joaquim da Fonseca sobre esse tipo de obra, que chama de caricatura pessoal, afirmando que esta "limita-se ao exagero das características físicas de uma pessoa" ${ }^{\text {32. }}$.

Assim, deixando de lado aspectos artísticos sobre a maior ou menor pretensão de uma caricatura, ou seja, se ela busca apenas um efeito humorístico ou se também tem um cunho psicológico, é possível nela encontrar três elementos básicos: a) deformação da imagem do retratado; b) objetivo humorístico e c) utilização da imagem de pessoas conhecidas.

\footnotetext{
${ }^{28}$ RIANI, Camilo. Linguagem \&cartum... tá rindo do quê?: um mergulho nos salões de humor de Piracicaba, p. 26.

${ }^{29}$ ROMUALDO, Edson Carlos. Charge jornalística: intertextualidade e polifonia: um estudo de charges da Folha de S. Paulo, p. 21.

${ }^{30}$ RIANI, Camilo. Linguagem \&cartum... tá rindo do quê?: um mergulho nos salões de humor de Piracicaba, p. 34.

${ }^{31}$ RIANI, Camilo. Linguagem \&cartum... tá rindo do quê? : um mergulho nos salões de humor de Piracicaba, p. 29.

${ }^{32}$ FONSECA, Joaquim da. Caricatura: a imagem gráfica do humor, p. 28.
} 
A caricatura tem como traço indispensável o exagero ou distorção de uma característica da pessoa a ser retratada. Assim, por exemplo, alguém muito magro pode ser associado a um objeto fino, como um poste, ou uma pessoa com nariz grande pode ser reproduzida como se tivesse um bico de ave.

Parece ser inegável que a caricatura tem na expressão humorística a sua maior vertente. É nessa forma em que ela quase sempre aparece e atinge notoriedade, bastando lembrar que é uma das categorias admitidas em concursos de obras humorísticas, como os dois salões do humor de Piracicaba: o Internacional e o Universitário.

Entretanto, nem sempre ela tem por objetivo fazer graça, já que, por recorrer à técnica de deformação de imagens, pode até mesmo causar medo ou horror. Assim, a reprodução monstruosa do rosto de uma pessoa, mais do que eventualmente fazer rir, poderá ter um caráter assustador, atingindo objetivo inverso do humorístico.

É sabido que a criação artística tem como objetivo gerar um sentimento estético em seu observador; esse sentimento, porém, não precisa ser necessariamente prazeroso, podendo o autor ter como objetivo causar uma sensação aflitiva, provocativa ou de repulsa por meio de sua obra ${ }^{33}$. Nesse sentido, Sylvia Helena Telarolli de Almeida Leite é clara ao afirmar que "a caricatura é criação associada ao cômico, apesar de nem sempre provocar o riso, podendo despertar o medo ou o horror" 34 .

Outra característica importante é que a pessoa caricaturada seja conhecida do público-alvo. Isso é relevante porque a caricatura é um jogo de semelhança e dessemelhança, ou seja, o objetivo de fazer graça ou de produzir o riso é alcançado quando o observador identifica na obra qual é a pessoa retratada. Mesmo tendo sido representada com características exageradas ou deformadas, a pessoa caricaturada é reconhecida em razão dos traços de semelhança utilizados na figura.

\footnotetext{
${ }^{33}$ A utilização da criação para causar horror não é tão rara, bastando lembrar a existência de muitas obras cinematográficas que exploram esse gênero e que, embora aflitivas para o público, são muito populares, conseguindo bilheterias milionárias.

${ }^{34}$ LEITE, Sylvia Helena Telarolli de Almeida. Chapéus de palha, panamás, plumas, cartolas: a caricatura na literatura paulista (1900-1920), p. 19.
} 
Para confirmar a importância dessas características acima citadas, merece destaque a notícia dada por Paulo Eduardo Ramos de que as obras humorísticas, ao serem inscritas para participarem do Salão Internacional do Humor de Piracicaba, SP (que exerce influência sobre os demais eventos da mesma espécie no Brasil), são classificadas como caricatura desde que contenham "deformação gráfica reconhecível de personalidades”35.

É necessário, porém, ter cuidado com a idéia de que os retratados devem ser personalidades $^{36}$. Essa exigência em um salão de humor é lógica, dada a grandeza desse tipo de evento, que se destina a um vasto público. Nesse caso, é compreensível que a obra recaia sobre alguém conhecido por grande gama de pessoas. Essa idéia, todavia, não deve ser levada a extremos, pois o que basta é que o retratado seja identificável pelo públicoalvo, que pode ser diminuto, como membros de uma família, estudantes de uma única classe em uma escola ou pequeno grupo de amigos. Logo, é caricatura tanto a imagem humorística deformada de um astro do cinema como aquela que retrata marido e mulher para ser vista apenas por eles no recesso do lar.

Neste trabalho, o termo "caricatura" será usado apenas para referir-se à caricatura de alguém, ou seja, o retrato humorístico de uma pessoa conhecida ou não, expresso de forma gráfica ou plástica, como a pintura, o desenho e a escultura, caracterizado pela deformação intencional da imagem do retratado.

\section{$\S 4^{\circ}$ Charge}

Palavra de origem francesa, derivada de charger, que significa carregar ou exagerar, a charge é conceituada por Camilo Riani como um "desenho humorístico sobre fato real ocorrido recentemente na política, economia, sociedade, esportes etc. Caracterizase pelo aspecto temporal (atual) e crítico"37. De acordo com Edson Carlos Romualdo, é o "texto visual humorístico que critica uma personagem, fato ou acontecimento político

\footnotetext{
${ }^{35}$ RAMOS, Paulo Eduardo. Tiras cômicas e piadas: duas leituras, um efeito de humor, p. 258.

${ }^{36}$ A palavra "personalidade", neste trabalho, refere-se a "pessoa famosa", independentemente dos motivos que a levaram a ser conhecida por muitos. Observe-se, porém, que o referido termo pode ser compreendido de forma mais restrita, como o faz Hermano Duval ao dizer que "personalidade é a afirmação de individualidade destacada em uma profissão, arte ou ofício, não sendo necessário que chegue a ser uma celebridade". (DUVAL, Hermano. Direito à imagem, p. 105).

${ }^{37}$ RIANI, Camilo. Linguagem \& cartum...tá rindo do quê?: um mergulho nos salões de humor de Piracicaba, p. 34.
} 
específico. Por focalizar uma realidade específica, ela se prende mais ao momento, tendo, portanto, uma limitação temporal" ${ }^{\prime 3}$.

É, portanto, o desenho que tem como objetivo, utilizando-se da via humorística, criticar fatos determinados. Em razão disso, até mesmo para facilitar a comunicação, pode ser elaborada identificando pessoas ou, ao contrário, trazer uma imagem que apenas remeta o público-alvo a reconhecer aquilo que está sendo criticado. Vale ressaltar que a charge que eventualmente retrate uma pessoa é assim construída para criticá-la enquanto participante de um acontecimento, e não com um objetivo simplesmente caricatural.

Como ocorre na caricatura, na charge é necessário que o público-alvo tenha conhecimento anterior sobre o objeto humorístico da criação intelectual. Naquela, o efeito engraçado é alcançado se a pessoa mostrada é conhecida, ficando claro o jogo de semelhança e dessemelhança entre a imagem real e a caricata; já nesta, é preciso que o contexto da imagem seja conhecido, e não apenas a pessoa mostrada, pois, sem essa informação prévia, não se entende a crítica humorística, pois quem entra em contato com os traços não entende plenamente ao que eles se referem. Assim, na caricatura, basta que se identifique a pessoa retratada; porém, no caso da charge, o conhecimento deve ser maior porque é necessário que se identifique pessoa ou fato e, também, seu contexto.

Tome-se a pessoa do Presidente da República como exemplo. É presumível que toda a população conheça a sua imagem. Desse modo, será facilmente obtida a finalidade humorística de uma caricatura, pois a deformação do aspecto visual da pessoa retratada é facilmente perceptível, eis que se trata de político conhecido nacionalmente. No caso da charge, porém, o número de pessoas que captarão o objetivo de crítica humorística do chargista será bem menor porque nem todas acompanham diariamente as notícias sobre o chefe do Poder Executivo. Como a charge é dinâmica e muito atual, quem não conhecer o fato específico nela retratado não identificará onde está o humor.

Como se referem a notícias atuais, as charges se renovam a cada dia. São como piadas diárias. É por esse motivo que se a caricatura de um político for divulgada diariamente, possivelmente perderá ou, ao menos, reduzirá, seu efeito cômico. Por outro

\footnotetext{
${ }^{38}$ ROMUALDO, Edson Carlos. Charge jornalística: intertextualidade e polifonia: um estudo de charges da Folha de S. Paulo, p. 21.
} 
lado, se esse mesmo político for chargeado diariamente, em virtude de novos fatos, as charges sempre serão novas e engraçadas.

As charges encontram local apropriado em jornais nas páginas de editorial, artigos e cartas de leitores, tendo como exemplo o que ocorre no jornal Folha de São Paulo. A charge, que tem na crítica política seu objeto preferido, é direta, mordaz e instantânea, pois é colocada justamente na seara onde os leitores que a compreenderão buscam esse tipo de mensagem e divertimento. Assim, essa forma de obra intelectual costumeiramente tem foco em alguma das notícias mais relevantes do dia e que está destacada no próprio jornal. É interessante notar, nesse aspecto, que os meios para a compreensão da charge são dados pelo próprio jornal; porém, o leitor não é obrigado a encontrá-los nessa forma de mídia impressa, pois pode eventualmente já ter conhecimento da notícia por outras formas mais velozes, como a televisão e o rádio. Não é raro que o leitor, por não ter muito tempo disponível ou por já ter opinião formada sobre o assunto, limite-se a ver a charge, divertindo-se com ela, sem precisar ler outros comentários.

Vale destacar que a charge, embora tenha morada perfeita nos jornais de mídia impressa, vem ganhando espaço na televisão e internet. Jornais televisivos vêm incorporando a charge aos seus conteúdos, incluindo elemento interessante, que é o movimento e fala das pessoas retratadas. $\mathrm{Na}$ internet, crescem os sites $^{39}$ dedicados ao humor valendo-se dessa modalidade de desenho.

Também é necessário lembrar que a seara política, embora de grande relevância, não é a única a ser retratada pelos chargistas, lembrando-se de outras áreas de atividade humana, como as artes e os esportes, exemplificando-se com o jornal paulistano $O$ Lance, especializado em esportes, que também utiliza charges, freqüentemente ligadas a temas futebolísticos.

Um exemplo de charge esportiva que causou polêmica é dado por Paulo Eduardo Ramos. Às vésperas de um jogo decisivo entre Corinthians e Santos, os jogadores deste clube foram à Basílica de Nossa Senhora Aparecida; de tal fato, foi divulgada uma charge

\footnotetext{
${ }^{39}$ Embora a língua portuguesa tenha a palavra sítio que pode perfeitamente apresentar o sentido de um "local dentro da internet", optou-se pela utilização do vocábulo de origem inglesa site porque é este muito freqüente nas referências à rede mundial de computadores e, também, por já estar registrado no Dicionário HOUAISS (Dicionário Houaiss da língua portuguesa, p. 2587).
} 
no jornal Última Hora mostrando a imagem da Padroeira do Brasil como tendo o rosto de Pelé.

Comparando-a com a caricatura, com a qual muitas vezes é confundida, pode-se dizer que na charge o humor é um "meio" para se alcançar o resultado, que é a crítica. A caricatura, por sua vez, tem basicamente o humor como "resultado" a ser alcançado, independentemente de tentar apresentar aspectos da personalidade do retratado.

Assim, em resumo, a charge, por meio humorístico, tem a finalidade de crítica a fatos determinados. Ela é pessoal e temporal.

\section{$\S 5^{\circ}$ Cartum}

Palavra advinda do vocábulo inglês cartoon, caracteriza-se como o desenho humorístico que aborda em sua temática fatos do cotidiano, sem identificação exata de pessoas. Tem somente por objetivo, assim, fazer graça de situações do dia-a-dia. Nas palavras de Camilo Riani, é um "desenho humorístico sem relação necessária com qualquer fato real ocorrido ou personalidade pública específica. Privilegia, geralmente, a crítica de costumes, satirizando comportamentos, valores e o cotidiano"40.

É pelo cartum que são retratadas as mais variadas situações corriqueiras que podem gerar humor, não havendo intenção direta de se fazer quaisquer tipos de críticas, como políticas ou sociais. Pode versar esse tipo de criação sobre uma grande variedade de temas, já que são múltiplas as formas de comportamento humano.

Não tendo outro objetivo senão o de fazer humor por si só, o cartum não identifica pessoas ou fatos, sendo, portanto, universal e atemporal. É nesse aspecto que se distingue da charge, pois, como já visto, esta tem exatamente o objetivo de criticar pessoas, idéias ou fatos, sendo, portanto, pessoal e temporal.

$\S 6^{\circ}$ Quadrinhos

\footnotetext{
${ }^{40}$ RIANI, Camilo. Linguagem \& cartum...tá rindo do quê?: um mergulho nos salões de humor de Piracicaba, p. 34.
} 
Os quadrinhos podem ser subdivididos em história em quadrinhos, comumente indicada pela sigla HQ, e tiras cômicas.

De acordo com Paulo Eduardo Ramos, história em quadrinhos "é o rótulo que ganha a maioria das histórias feitas com a linguagem dos quadrinhos, quando são veiculadas na forma de uma revista, livro ou fanzine (revista independente feita geralmente com folhas de sulfite)",41. No entender de Camilo Riani, é a "história desenhada/desenvolvida em distintas etapas/quadros seqüenciais, com roteiro e trama"42.

Nas histórias em quadrinhos há, geralmente, uma página de apresentação que contém o título da história e o nome de seu autor. No final, é comum haver a palavra "fim" ou "continua no próximo número", se for história seriada.

Mister se faz destacar algumas características gráficas e de linguagem comumente indicadas pelos autores especializados em quadrinhos: a) desenhos inseridos em quadros dispostos seqüencialmente; b) personagens regulares; c) formato da página; d) balões; e) caixa (box) de texto ou recordatório; f) onomatopéias; g) metáforas visuais; h) linhas de movimento ou linhas cinéticas.

Com relação à característica do item "a" (desenhos inseridos em quadros dispostos seqüencialmente), pode-se afirmar que é a mais importante, a que mais caracteriza esse tipo de obra. De acordo com Joaquim da Fonseca, as histórias em quadrinhos têm como elemento básico da linguagem o painel, que é

um desenho simples encerrado em uma moldura geralmente retangular ou quadrada, que fica ao mesmo tempo isolado e em relação íntima com os outros painéis da sequiência, da mesma forma que uma palavra numa frase. Os painéis são agrupados em tiras (a tira é um grupo de painéis em sequiência) ou em páginas. ${ }^{43}$

\footnotetext{
${ }^{41}$ RAMOS, Paulo Eduardo. Tiras cômicas e piadas: duas leituras, um efeito de humor, p. 268.

${ }^{42}$ RIANI, Camilo. Linguagem \& cartum...tá rindo do quê?: um mergulho nos salões de humor de Piracicaba, p. 34 .

${ }^{43}$ FONSECA, Joaquim da. Caricatura: a imagem gráfica do humor, p. 27.
} 
A sequiência dos quadros mostra a passagem do tempo, dando as informações mais importantes para a narrativa. As histórias devem ser lidas, quase sempre, de cima para baixo e da esquerda para a direita.

Essas narrativas contam com personagens regulares, lembrando Anselmo Gimenez Mendo que "com freqüência, as próprias publicações recebem o nome de seus heróis" mesmo autor indica que o formato padrão das revistas em quadrinhos é o americano (17 x $26 \mathrm{~cm})^{45}$.

A presença dos balões é relevante para os quadrinhos. Conforme lição de Edson Carlos Romualdo, o balão é "um texto fechado em um volume delimitado por uma linha contínua" 46 , sendo ligado ao personagem por um apêndice. Tem ele duas espécies básicas: o balão-fala e o balão-pensamento, que são explicados pelo autor citado da seguinte maneira:

- o "balão-fala": o mais comum, com um contorno bem nítido e contínuo. $\mathrm{O}$ apêndice sai da boca do falante em forma de seta;

- o "balão-pensamento": neste, a linha de contorno é irregular, ondulada, quebrada ou de pequenos arcos ligados. O apêndice, formado por pequenas bolhas ou nuvenzinhas, sai do alto da cabeça do pensante. $^{47}$

Diversas são as outras formas de balões, como o balão-cochicho, o elétrico, o ondulado e o mudo, mencionados por Anselmo Gimenez Mendo ${ }^{48}$. Edson Carlos

\footnotetext{
${ }^{44}$ MENDO, Anselmo Gimenez. Histórias em quadrinhos: impresso vs. web, p. 33.

${ }^{45}$ MENDO, Anselmo Gimenez. Histórias em quadrinhos: impresso vs. web, p. 34.

${ }^{46}$ ROMUALDO, Edson Carlos. Charge jornalística: intertextualidade e polifonia: um estudo de charges da Folha de S. Paulo, p. 29.

${ }^{47}$ ROMUALDO, Edson Carlos. Charge jornalística: intertextualidade e polifonia: um estudo de charges da Folha de S. Paulo, p. 29.

48 "balão-cochicho: semelhante ao da fala, mas com as letras em tamanho bastante reduzido.

balão-elétrico: com bordas em ziguezague representando o som emitido por aparelhos elétricos ou eletrônicos.

balão-ondulado: representando temor ou medo.

balão-mudo: sem texto, utilizado algumas vezes quando o personagem parece atônito" (Histórias em quadrinhos: impresso vs. web, p. 35-36).
} 
Romualdo, por sua vez, além de referir-se ao balão-cochicho, elenca também o balãoberro, o trêmulo e o de-linhas-quebradas ${ }^{49}$.

Por meio deles tornou-se mais fácil evidenciar o comportamento dos personagens, facilitando a compreensão da história pelos leitores.

Já as caixas de texto ou recordatórios, segundo Anselmo Gimenez Mendo,

são também receptáculos de texto como os balões. Geralmente em formato de caixa, aparecem na maioria das vezes no interior dos quadros. Podem conter a palavra do narrador da história, o pensamento de algum personagem, informações sobre passagem de tempo, entre outras funções. Em histórias seriadas, servem de espaço para recordação de acontecimentos passados. ${ }^{50}$

As onomatopéias têm como função indicar um determinado som existente na cena mostrada no quadro, como a onomatopéia "tchibum", para mostrar o som de alguém mergulhando, e o "bum", originado de uma explosão.

Exemplos de metáforas visuais são dados por Anselmo Gimenez Mendo, como a imagem de uma lâmpada acesa que mostra o surgimento de alguma idéia nova de um personagem, ou bombas e pregos para substituir xingamentos, acrescentando o autor que esse recurso de linguagem é mais encontrado em quadrinhos humorísticos ${ }^{51}$.

As linhas de movimento, ou cinéticas, têm como função, como a própria expressão indica, representar o deslocamento de personagens e sua velocidade. É um importante recurso para permitir que no desenho impresso, estático por natureza, possa ser incluída a noção de movimento.

\footnotetext{
49 “o "balão-cochicho": nele, a linha de contorno é pontilhada. É usado quando se quer representar a fala de uma personagem que não pode ser ouvida por um terceiro;

o "balão-berro": formado por arcos com as extremidades voltadas para fora;

o "balão-trêmulo": possui as linhas tortuosas e indica o medo que o falante sente ou que quer transmitir;

o "balão-de-linhas-quebradas": representa os sons e falas emitidos por aparelhos elétricos ou eletrônicos" (Charge jornalística: intertextualidade e polifonia: um estudo de charges da Folha de S. Paulo, p. 30).

${ }^{50}$ MENDO, Anselmo Gimenez. Histórias em quadrinhos: impresso vs. web, p. 37.

${ }^{51}$ MENDO, Anselmo Gimenez. Histórias em quadrinhos: impresso vs. web, p. 39.
} 
Destaque-se que a forma de linguagem das histórias em quadrinhos, com seus balões de fala e de pensamento e onomatopéias, entre outros elementos, também pode ser utilizada em outras espécies de humor gráfico, como a caricatura, o cartum e a charge, sendo mais comum nesta última.

Como exemplos de histórias em quadrinhos podem ser citadas a Turma da Mônica, criada por Maurício de Sousa e as aventuras de super-heróis, como o Homem-Aranha, de Stan Lee e Batman, criado por Bob Kane.

Mister se faz ressalvar que as histórias em quadrinhos não se limitam ao objetivo humorístico, ramificando-se em uma variada gama de finalidades, como entretenimento (histórias de ficção e aventura, por exemplo), pedagógica, histórica, informativa entre outras. É o caso da Receita Federal do Brasil, que se vale de pequenas revistas dando explicações sobre impostos, atenuando uma linguagem que pode ser enfadonha se não vier acompanhada de outros elementos de comunicação. Campanhas de vacinação e de conscientização na área da saúde também têm obtido sucesso por intermédio dos quadrinhos, não sendo demais lembrar a existência do amplamente conhecido personagem Zé Gotinha. Além disso, observa-se que informações científicas e fatos históricos podem ser mais facilmente compreendidos pelo público infantil por meio desse tipo de criação intelectual.

Já no caso das tiras cômicas, como a própria expressão denota, o humor é elemento imprescindível. Elas têm como aspecto muito importante o formato, que deve ser em "tiras", que podem ser apresentadas horizontalmente (o mais comum) ou verticalmente.

As tiras cômicas geralmente são publicadas em jornais, nas páginas dedicadas a passatempos, juntamente com cruzadinhas e horóscopos. São vistas como forma de distração, separadas do conteúdo noticioso do veículo de imprensa.

Como exemplos podem ser citadas as conhecidas histórias do Garfield, criação de Jim Davis, Hagar, o Terrível, da autoria de Dik Browne, Geraldão, de Glauco, e Rê Bordosa, de Angeli. 
A idéia da tira cômica é contar uma história completa em poucos quadros, fazendo graça e, de acordo com Paulo Eduardo Ramos, com a "tendência de criar um desfecho inesperado, como se fosse "uma piada por dia"

\section{$\S 7^{\circ}$ Anedotas}

Mister se faz perquirir a extensão das palavras "anedota" e "piada" no concernente ao humorismo. Por meio de consulta a dois importantes dicionário, o AURÉLIO e o HOUAISS, verifica-se que o vocábulo "anedota" tem sentido mais rente ao humorismo, já que a palavra "piada" possui outros sentidos, como, exemplificando-se, o ato de piar.

Conforme registra o AURÉLIO, a palavra anedota é "o relato sucinto de um fato jocoso ou curioso" ou "particularidade engraçada de figura histórica ou lendária",53; já, segundo indica o HOUAISS, esse vocábulo tem o sentido de "particularidade curiosa ou jocosa que acontece à margem dos eventos mais importantes, e, por isso ger. pouco divulgada, de uma determinada personagem ou passagem histórica" ou "narrativa breve de um fato engraçado ou picante",54.

No concernente à palavra piada, informa o AURÉLIO que se trata de "dito engraçado e espirituoso; pilhéria; chiste" ${ }^{, 55}$ e o HOUAISS, por sua vez, expõe que ela se refere a "dito ou alusão engraçada" ou "história curta de final surpreendente, às vezes picante ou obscena, contada para provocar risos" $" 56$.

\footnotetext{
${ }^{52}$ RAMOS, Paulo Eduardo. Tiras cômicas e piadas: duas leituras, um efeito de humor, p. 288.

${ }^{53}$ Para o verbete são registrados os seguintes sentidos: “anedota. [Do gr. anékdotos, 'inédito', atr. do fr. anecdote.] S. f. 1. Relato sucinto de um fato jocoso ou curioso. 2. Particularidade engraçada de figura histórica ou lendária." (Novo dicionário Aurélio da língua portuguesa, p. 118).

${ }^{54}$ Para o verbete são registrados os seguintes sentidos: "anedota $s . f$. (1727 cf. RB) 1 particularidade curiosa ou jocosa que acontece à margem dos eventos mais importantes, e por isso ger. pouco divulgada, de uma determinada personagem ou passagem histórica 2 p.ext. narrativa breve de um fato engraçado ou picante (...)" (Dicionário Houaiss da língua portuguesa, p. 211).

${ }_{55}$ Para o verbete são registrados os seguintes sentidos: "piada. [Fem. substantivado de piado, part. de piar.] S. f. 1. V. pio (2). 2. V. estertor (1). 3. Dito engraçado e espirituoso; pilhéria, chiste. 4. Chalaça picante. 5. V. picuinha (2). 6. Conversa fiada; lorota". (Novo dicionário Aurélio da língua portuguesa, p. 1323).

${ }^{56}$ Para o verbete são registrados os seguintes sentidos: "piada $s . f$. (1858 cf. MS) 1 voz característica de certas aves e animais; pio 2 m.q. ESTERTOR 3 dito ou alusão engraçada <fazia pequenas p. sobre o comportamento do chefe $>\mathbf{4}$ história curta de final surpreendente, às vezes picante ou obscena, contada para provocar risos $<$ contou uma p. grosseira sobre um macaco lascivo $>\mathbf{5}$ alguém ou algo que tem má qualidade ou é ridículo, esp. quando demonstra pretensão infundada <esse cara é uma p. $><$ o filme era uma p. $>\mathbf{6}$ conversa mole, lorota (...)" (Dicionário Houaiss da língua portuguesa, p. 2205).
} 
Nota-se, pois, que ambas palavras têm o sentido de um breve relato de algo engraçado, com o objetivo de provocar o riso. Assim, conclui-se que no atinente ao humorismo, "anedota" e "piada" são vocábulos sinônimos.

A piada é entendida por Paulo Eduardo Ramos como "uma narrativa tendencialmente curta, com personagens fixos ou não. Ela possui necessariamente um desfecho inesperado, que leva a uma inferência e a um efeito de humor"57. Derek Brewer a define como "uma narrativa breve de alguma diversidade curiosa, incongruência ou réplica inteligente, personificando e atraindo um grupo de pessoas de gostos parecidos" ${ }^{\text {"58. }}$.

Tendo em vista essa idéia de piada como uma "história curta", as primeiras formas de expressão anedótica que vêm à mente são a escrita e a oral, por meio das quais a mensagem humorística é transmitida ao público receptor.

As piadas, entretanto, não se limitam às formas escritas ou verbais, mesmo que estas sejam extremamente comuns no dia-a-dia. Possivelmente, o que primeiro se pensa quando se fala em anedota seja a imagem de uma pessoa indagando a outra da seguinte maneira: "conhece aquela do papagaio?" ou "sabe aquela do português?" antes de contar a piada. A forma oral é quotidiana, não sendo exagero afirmar que é o melhor meio de expressão da anedota, já que pode vir acompanhada de entonação compatível com o que se está dizendo ou, até mesmo, de mudanças de vozes quando há mais de um personagem.

Além da divulgação "boca a boca", a recepção auditiva das piadas pode se dar por intermédio de telefone, rádio, $\mathrm{CD}$ etc.

A forma escrita também é freqüentemente utilizada para a divulgação de piadas, o que pode ocorrer por jornais, revistas, livros, correio eletrônico e outras formas digitais. Assim, a recepção das anedotas pode se dar por meio da leitura.

É importante destacar que piadas também podem ser transmitidas ao público por meio de expressão corporal, tendo a mímica ou a pantomima como exemplos. Até mesmo

\footnotetext{
${ }^{57}$ RAMOS, Paulo Eduardo. Tiras cômicas e piadas: duas leituras, um efeito de humor, p. 149.

${ }^{58}$ BREWER, Derek. Livros de piada em prosa predominantes na Inglaterra entre os séculos XVI e XVIII, p. 133.
} 
as obras cinematográficas humorísticas antigas, que não eram acompanhadas de falas, tinham como característica a transmissão das anedotas de forma não oral ou não escrita. Os filmes de Charles Chaplin e seu inesquecível personagem Carlitos bem exemplificam as piadas sem palavras. 


\title{
CAPÍtUlO 2. O HUMOR E SUA RELEVÂNCIA PARA OUTROS RAMOS DO CONHECIMENTO
}

\author{
Seção I. Política
}

O humor tem grande relevância como manifestação política, eis que, por meio daquele, esta pode ser exercida de maneira mais sutil, esquivando-se de reações contrárias das pessoas atingidas pelo animus jocandi ou, até mesmo, de governos ditatoriais.

A crítica social e política se torna mais aguda quando feita de maneira engraçada. $\mathrm{O}$ brocardo latino ridendo castigat mores, rindo castigam-se os costumes, bem indica o caráter devastador que pode ter a crítica humorística.

Como dizer a uma pessoa irascível que ela fez algo errado ou tem opinião equivocada? É mais seguro dizê-lo de forma bem humorada, fazendo gracejos que disfarcem a exata intenção do comentário. Essa maior facilidade de dizer a verdade é retratada pelo brocardo latino ridendo dicere verum, rindo diz-se a verdade.

Muitas vezes as pessoas procuram dizer a verdade valendo-se de afirmações em tom de piada, sob o manto do humor, que as atenua. É possível, portanto, afirmar que a conduta humorística pode proteger quem a pratica. Conforme noticia Jan Bremmer, na Grécia antiga existia a figura dos bufões, que eram comediantes que conseguiam até mesmo ser aceitos em jantares para os quais não foram convidados, desde que, para isso, praticassem atos cômicos como, por exemplo, contando piadas, dançando ou fazendo imitações engraçadas ${ }^{59}$.

É nessa atmosfera de maior proteção ao humorista que a crítica política ganhou força. Quem poderia fazer piadas com o rei sem correr grande risco de ser severamente punido? A resposta a essa indagação vem de Luis Fernando Veríssimo: “... a nossa tradição é a do bobo da corte. E o bobo da corte tem licença para caçoar do rei com o único risco de o rei não entender a piada e dar um chute nele" ${ }^{\sharp 00}$.

\footnotetext{
${ }^{59}$ BREMMER, Jan. Piadas, comediógrafos e livros de piadas na cultura grega antiga, p. 29-34.

${ }^{60}$ VERÍSSIMO, Luis Fernando. Charge não ofende, p. 10.
} 
Nesse sentido, tanto a paródia como a charge têm alcançado destaque nos meios de comunicação, já que são formas de rápida e fácil compreensão pelo público. Muitas vezes, quando o regime governamental é extremamente repressor, não restam muitas opções aos criadores senão recorrer às mensagens engraçadas.

Essa atividade humorística, principalmente em relação ao caráter político que pode ter, encontra respaldo no direito de crítica, que é decorrência do direito de liberdade de expressão, protegido constitucionalmente.

Na história brasileira, a importância da atividade humorística pode ser lembrada no concernente ao período de ditadura militar imposto na década de sessenta. Em um período em que houve forte restrição à liberdade de manifestação do pensamento, a criação artística foi importante instrumento de resistência, podendo ser citadas como exemplos a música e a literatura. Os grandes festivais de música tornaram-se eventos prestigiados por estudantes e assistiram ao surgimento de autores de altíssimo nível.

No tocante a programas de música nessa época, um exemplo de humor como crítica social ocorreu na música Comedor de Gilete (pau de arara), de Carlos Lyra e Vinícius de Moraes, feita para a peça Pobre menina rica e interpretada por Ary Toledo, cuja letra narrava as agruras de um imigrante nordestino na cidade do Rio de Janeiro, que dançava chachado nas praias de Copacabana e resolveu começar a comer giletes para auferir mais renda.

Durante a apresentação dessa obra lítero-musical no programa $O$ Fino da Bossa exibido pela TV Record, o público (e a apresentadora Elis Regina) ria em diversos momentos em razão da letra e da interpretação engraçadas; parecia tratar-se de criação com finalidade exclusivamente humorística. Porém, além de mostrar a situação de miséria de parte da população, o final da letra continha as frases "vou picar minha mula / vou antes que tudo rebente / porque tô achando que o tempo tá quente / pior do que anda não pode ficar!", e a apresentação foi seguida de grande aplauso. É viável aventar a hipótese de que o intenso aplauso vindo das pessoas presentes no teatro veio estimulado pelo ambiente de efervescência política da década de sessenta. O público teria entendido que aquela frase, embora pertinente com o que foi narrado na canção, tinha significado maior, ou seja, a 
repressão estava aumentando, havia perigo para aqueles que tinham opinião diferente e do jeito que o Brasil estava não poderia continuar.

Quanto mais criativa fosse a obra, maior seria a possibilidade de passar a mensagem de luta contra a ditadura, sem o risco de sofrer represálias.

Ainda durante o regime militar, programas de televisão tiveram conotação política. Vale mencionar o trabalho de Jô Soares que, em diversos programas da TV Globo, como, por exemplo, Planeta dos Homens e Viva o Gordo, apresentava críticas ao governo. A Rádio Cruzeiro, quadro anedótico apresentado por Jô Soares e por Paulo Silvino, claramente criticava a economia brasileira, em especial a sua submissão aos interesses estrangeiros representados pelo FMI - Fundo Monetário Internacional.

Em entrevista concedida a Miriam Sanger e a Sérgio Miguez para a Revista da Cultura $^{61}$ o citado humorista e escritor lembrou o interessante caso do personagem Gandola. Tratava-se de um quadro televisivo que mostrava uma pessoa que, em uma conversa, ao avisar ao seu interlocutor que foi mandada ali pelo citado personagem ("quem me mandou aqui foi o Gandola...”), era beneficiada. Após um ano e meio em que o personagem vinha sendo exibido, percebeu-se que gandola é o nome de uma vestimenta do exército, e o quadro foi retirado do ar.

Também a obra lítero-musical pode, sob o véu do humorismo, ter caráter crítico. Lembre-se a canção Aluga-se, de Raul Seixas, que, com humor carregado de ironia, apresenta o seguinte texto:

A solução pro nosso povo eu vou dar

Negócio bom assim ninguém nunca viu

Tá tudo pronto aqui é só vir pegar

A solução é alugar o Brasil!

Nós não vamos pagar nada

Nós não vamos pagar nada

É tudo free,

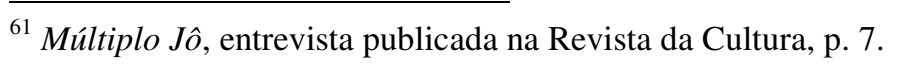


Tá na hora agora é free,

vamo embora

Dar lugar pros gringo entrar

Esse imóvel tá prá alugar

Os estrangeiros, eu sei que eles vão gostar

Tem o Atlântico, tem vista pro mar

A Amazônia é o jardim do quintal

E o dólar deles paga o nosso mingau ...

A canção mostra claro caráter humorístico e irônico, pois narra uma opinião que certamente não é a que realmente tem o cantor. Obviamente, esse negócio (aluguel do Brasil) não seria bom como indica a letra e o trecho que comemora que o dinheiro vindo do exterior "paga o nosso mingau" transmite a idéia de recebimento de esmola, de um povo pobre que precisa ser alimentado por estrangeiros em troca da soberania nacional.

Ainda nesse período da história brasileira, marcado também pelo incentivo governamental ao nacionalismo, propagando-se a idéia de que o Brasil estava se tornando uma potência em várias áreas, desde o futebol até o jogo de $\mathrm{xadrez}^{62}$, ficou famoso o slogan "Brasil, ame-o ou deixe-o", que Juca Chaves ironizou com a seguinte resposta: “então, o último que sair, apague a luz do aeroporto".

Henrique de Sousa Filho, conhecido pelo pseudônimo Henfil, em entrevista concedida a Tárik de Souza, lembrou que os humoristas de então desmoralizavam campanhas publicitárias governamentais, como a citada "Brasil, ame-o ou deixe-o", além de "Mexa-se" e "Ninguém segura este país". Vale aqui transcrever exemplo narrado pelo citado humorista:

(...) Tinha uma campanha que era a favor do uso da bicicleta. Obviamente, deveria ser patrocinada pela Monark-Calói. Mas era

\footnotetext{
${ }^{62}$ O Brasil obteve grandes conquistas futebolísticas, tanto com a seleção em 1970, que venceu a Copa do Mundo no México, como também por sucessos de clubes, como o Santos que, com Pelé e outros craques, tornou-se um time muito difícil de ser batido. Também no jogo de xadrez, que é considerado um esporte e está organizado por uma Federação Internacional (FIDE - Federation Internacionale des Echécs), esporte esse marcado pelo uso do raciocínio lógico e do controle emocional, o país passou a ter um representante entre os melhores do mundo, o enxadrista gaúcho Henrique da Costa Mecking, conhecido como Mequinho, que chegou a ser o terceiro colocado na ranking internacional e semifinalista do Torneio de Candidatos para a disputa do título mundial.
} 
aquela coisa hipócrita de economia de combustível. Então, era pra andar de bicicleta. Como se economizasse alguma coisa isso. Então, o João Figueiredo, como atleta da época ia andar de bicicleta numa propaganda... E eu soube, por baixo do pano, através de alguém ligado á própria agência que ia ter esta campanha. "Olha! Vai ter uma campanha aí e é bom você falar". É o tipo da encomenda que eu aceito com o maior prazer. Nesta época tinha havido o seqüestro da Lílian Celiberti e do Universindo Dias pelo Didi Pedalada. Então, eu publique um cartun na ISTO É, que era o João passando, de bicicleta, todo de vestido de atleta e alguém comentando. "Ih, olha lá o João Pedalada". Bom, a campanha morreu aí. ${ }^{63}$

Diante da grande importância do humor na esfera política, não é por acaso, portanto, que em outros países, como informa Joaquim da Fonseca, governantes como Benito Mussolini, na Itália, e Perón, na Argentina, tenham proibido por lei que fossem caricaturados ${ }^{64}$.

Obras cinematográficas também podem conter humor político. Veja-se o exemplo do excelente filme, talvez um dos melhores de todos os tempos, $O$ grande ditador (de 1940, com direção de Charles Chaplin); em que, além de um título que não dava margem a dúvida sobre a forte crítica a Hitler, e todo o restante, até um final que pregava a paz, uma cena ficou inesquecível: aquela em que Charles Chaplin dançava com um globo terrestre que flutuava como uma bexiga; parecia ser algo risível, mas indicava o desvario existente no objetivo de alguém dominar o mundo. Ali, não eram necessárias palavras ou cores, o humor bastava para mostrar aquilo a que se pretendia criticar.

Outro exemplo está no filme Bananas (de1971, dirigido por Woody Allen), obra essa que foi taxada por Henfil como sendo um exemplo de humor de direita, pois a forma como mostrava o país fictício São Marcos era altamente preconceituosa com relação aos latino-americanos e justificaria o bloqueio a Cuba e a invasão à Nicarágua ${ }^{65}$. Nessa obra cinematográfica, o personagem de Woody Allen mostra uma pessoa tola e atrapalhada que, mesmo contra sua vontade e por motivos circunstanciais, torna-se um guerrilheiro que

\footnotetext{
${ }^{63}$ HENFIL. Como se faz humor político, p. 49-50.

${ }^{64}$ FONSECA, Joaquim da. Caricatura: a imagem gráfica do humor, p. 12.

${ }^{65}$ HENFIL. Como se faz humor político, p. 84.
} 
chega ao poder em um golpe de estado, sucedendo o líder oposicionista que havia enlouquecido tão logo assumira o comando do país.

Também na indústria cinematográfica nacional o humorismo teve papel significativo, bastando lembrar as chanchadas, que tiveram expoentes como os atores Grande Otelo e Oscarito. Essas películas originaram-se do teatro de rebolado e foram muito populares no século passado em seus anos quarenta, cinqüenta e início dos sessenta, reunindo elementos atrativos para o público, como a música, a dança, a sensualidade ${ }^{66}$ e a crítica social e política, além do humorismo.

Debruçando-se sobre o assunto, William Reis Meirelles ensina que

a chanchada era um gênero de divertimento que reunia características variadas e acumuladas pela comédia popular ao longo da história. Esse gênero de filme, um tipo de comédia musical, incorporou tanto nos seus enredos como nas formas, elementos do circo, do rádio, do cinema estrangeiro e do teatro de variedades - a versão nacional do vaudeville francês, aqui popularmente conhecido como 'teatro de rebolado'. ${ }^{67}$

As chanchadas, obras de engenho voltadas para as classes populares, configurando um cinema de massas e contrariando o que se pode chamar de cinema de arte, encontraram resistência das camadas mais abastadas, que as desprezavam e desqualificavam. O que se deve questionar é se a repulsa dos ricos a esse tipo de cinema tinha base apenas em um gosto artístico mais refinado. É possível aventar que a desaprovação às chanchadas, além de ligar-se a critérios estéticos, também deitava raízes nas críticas sociais e políticas que elas traziam consigo, já que esse gênero de obra cinematográfica freqüentemente se valia da paródia como forma de mensagem crítica a pessoas ou instituições. Para os mais ricos

\footnotetext{
${ }^{66}$ Afrânio Mendes Catani e José Inácio de Melo Souza explicam de forma bem humorada a presença de belas mulheres nas chanchadas. Segundo eles, "boa parte dos homens, durante certo tempo, dava o dinheiro e despachava a patroa com as crianças para as matinês nos fins de semana - dias importantíssimos consumidos entre intermináveis goles de Brahma e lances de Vasco, Flamengo, Fluminense, Coríntians, Palmeiras e outros menos cotados. Entretanto, depois de algumas constatações elementares, os produtores das chanchadas descobriram a fórmula infalível de trazer a família inteira para as salas escuras: era necessário deixar à mostra as bem torneadas coxas de Cuquita Carballo e Maria Antonieta Pons, importadas diretamente da Pelmex. E assim, tudo entrava nos eixos: família unida, receita garantida." (A chanchada no cinema brasileiro, p. 8788).

${ }^{67}$ MEIRELLES, William Reis. Paródia \& chanchada: imagens do Brasil na cultura das classes populares, p. 91.
} 
poderia ser bastante desagradável ver nas telas de cinema a imagem de pessoas pobres e humildes, desprovidas de participação e poder político. Além disso, mais desagradável ainda seria ver uma criação intelectual, mascarada e protegida pela veia humorística, abordando impunemente a realidade de injustiça social reinante no país.

Nesses filmes, por trás de um humor escancarado e simples, valendo-se de elementos populares como o carnaval, os personagens retratando pessoas interioranas pouco instruídas, as músicas, as mulheres bonitas ou os cidadãos simples de camadas sociais mais baixas das grandes cidades, podia estar a crítica política. O humor dificultava a resistência ao que se estava dizendo pois a forma engraçada das chanchadas permitia manifestações contra governantes e injustiças sociais, sem que essas obras pudessem ser facilmente impedidas porque, à primeira vista, se limitavam meramente ao objetivo de fazer rir.

Aos governantes e às camadas dominantes não era agradável ver a imagem de um Brasil desigual aos brasileiros. Com a popularidade alcançada pelas chanchadas, alguns problemas nacionais ficavam implícitos (ou até mesmo explícitos) na linguagem artística adotada e as mazelas do país podiam ser mostradas com forte aceitação popular, eis que, conforme expressão utilizada por Afrânio Mendes Catani e José Inácio de Melo Souza, as chanchadas apresentavam "o povão nas telas"68.

Um exemplo de crítica política e social é dado por William Reis Meirelles. Trata-se da paródia Nem Sansão Nem Dalila (de 1954, dirigida por Carlos Manga), cujo título deixa claro o propósito de copiar humoristicamente a obra cinematográfica Sansão e Dalila (de 1949, com direção de Cecil B. De Mille).Esse filme narra as peripécias do humilde Horácio, personagem de Oscarito, que volta no tempo e vai para o Reino de Gaza onde conhece Sansão, do qual recebe sua peruca em uma troca com um isqueiro. A força de Sansão vinha dessa peruca. A partir daí, poderoso, Horácio passa a governar e a fazer falsas promessas à população. A crítica política era tão diretamente destinada a Getúlio Vargas, presidente do Brasil na época, que o personagem vivido por Oscarito repetia os mesmos discursos e promessas feitos por Vargas na vida real.

\footnotetext{
${ }^{68}$ CATANI, Afrânio Mendes; SOUZA, José Inácio de Melo. A chanchada no cinema brasileiro, p. 65.
} 
Na década de setenta desenvolveram-se as chamadas pornochanchadas, que seriam uma forma de retomada das chanchadas, porém com apelo sensual muito maior. É válido dizer, porém, que a denominação "pornochanchada" é até mesmo inadequada por se tratar de um tipo de obra que poucos traços equivalentes apresentava em relação às chanchadas, se limitando à veia humorística empregada em diversas criações, como o filme Histórias que nossas babás não contavam (de 1979, dirigida por Oswaldo de Oliveira), paródia da obra Branca de neve e os sete anões. O viés da sensualidade que passou a ser explorado era muito maior do que havia nas décadas anteriores, o que é explicável pela evolução dos costumes na época da chamada revolução sexual.

Apesar das críticas dirigidas ao seu valor artístico, já que eram películas de baixo custo, sem temática de crítica política e destinadas às camadas mais populares, deve-se lembrar que as pornochanchadas foram muito rentáveis e dominaram o cinema nacional até a década de oitenta, tornando-se importantes para a sobrevivência do cinema brasileiro, que estava oprimido em razão da repressão política e também enfrentava a concorrência de obras estrangeiras, principalmente as norte-americanas.

\section{Seção II. Medicina}

A boa qualidade de vida tem relação com o estado emocional do ser humano. Não depende de demonstração que a forma de encarar a vida é diferente entre as pessoas, existindo diversas variáveis quanto ao bom humor.

Os seres humanos são muitas vezes rotulados de "bem-humorados" ou "malhumorados" e essa forma popular de classificação da forma de comportamento de cada indivíduo tem grande poder. Não é raro que pessoas tidas como "mal-humoradas" enfrentem resistência em seus locais de trabalho e no grupo social em que estão inseridas, várias vezes sendo colocadas de lado.

Além desse aspecto de maior ou menor aceitação social que o humor de uma pessoa pode implicar, este tem, ademais, grande relevância no aspecto psicológico e no funcionamento do corpo humano. 
Pessoas tensas, que não conseguem ter momentos de maior alegria e descontração, enfrentam mais problemas de saúde e podem estar mais propensas a doenças cardíacas e males do sono, por exemplo. Essa situação está relacionada à maior produção do hormônio adrenalina que, apesar de ser útil porque prepara o corpo humano para uma rápida reação em momentos de perigo ou de combate, quando produzido em excesso e desnecessariamente, apresenta efeitos nocivos à saúde.

Por outro lado, os seres humanos mais calmos e alegres apresentam maior produção das chamadas endorfinas, hormônios originados na glândula hipófise e que, em uma linguagem mais simples, são parecidos com substâncias analgésicas e, em razão disso, causam uma sensação de bem-estar.

Pode-se dizer, portanto, que os atos humorísticos, por terem como intenção levar as pessoas ao riso ou a um bem-estar emocional, são úteis como elementos para prevenir ou acelerar a cura de doenças, tanto orgânicas como emocionais.

É conhecida a chamada "terapia do riso" ou "risoterapia". A alegria, desde uma demonstração mais contida até uma contagiante gargalhada, tem efeito prazeroso e relaxante, podendo combater o estresse, está a merecer melhor atenção pelos profissionais da área da saúde.

A terapia do riso está incluída em um conceito maior, denominado "humanização do atendimento médico", e baseia-se na busca da alegria, por meio do humor, como forma de tratamento, já existindo no Brasil atividades nesse sentido exercidas por grupos como os Doutores da Alegria, Hospitalhaços e Caminho da Alegria.

O Doutores da Alegria é composto por atores que se vestem de palhaços para visitar hospitais na área de atendimento infantil. Esse grupo se formou na cidade de São Paulo e agora se ramificou para outras cidades.

Já a agremiação Hospitalhaços, também constituída por atores, formou-se para atuação inicialmente no Hospital de Clínicas da UNICAMP, Universidade de Campinas, no interior do Estado de São Paulo, tendo expandido suas atividades para diversas cidades 
da região, como Sumaré e Paulínia, chegando ao Estado de Goiás, em sua capital, a cidade de Goiânia. O atendimento é prestado tanto para crianças como para adultos.

O grupo Caminho da Alegria foi fundado na cidade de Jundiaí, no Estado de São Paulo, por alunos da Faculdade de Medicina desse município.

Há indícios de que o trabalho desses abnegados voluntários apresenta resultados positivos não apenas na aceitação dos tratamentos pelos pacientes, que muitas vezes estão em situação crítica, até mesmo em estágio terminal, como também na aceleração da recuperação desses enfermos, quando essa é possível. É significativa a melhora da autoestima dos pacientes com a presença amiga de um palhaço que ali está procurando trazer um pouco de humor e calor humano.

Mesmo que um médico não possa curar um paciente, eis que a Medicina ainda não tem a solução para muitos males, ele pode, com a humanização do atendimento e o humor, melhorar a qualidade de sobrevida dos doentes.

Essas louváveis iniciativas se iniciaram nos Estados Unidos da América do Norte, tendo como figura importante o médico Patch Adams, cujo nome verdadeiro é Hunter Adams, e que teve sua história de vida levada ao cinema por meio da película Patch Adams: o amor é contagioso (de 1988, dirigido por Tom Shadyac), que contou com o ator Robin Willians interpretando o médico norte americano. 


\section{PARTE 2 - O HUMOR E SUA RELEVÂNCIA PARA O DIREITO}

\section{CAPITULO 1. OS DIREITOS AUTORAIS E OS DIREITOS DA PERSONALIDADE}

Seção I. Direito de autor

Conforme o ensinamento de Carlos Alberto Bittar, "Direito de Autor ou Direito Autoral é o ramo do Direito Privado que regula as relações jurídicas, advindas da criação e da utilização econômica de obras intelectuais estéticas e compreendidas na literatura, nas artes e nas ciências" $"$.

Antônio Chaves, por sua vez, faz uma definição mais ampla e completa, ao ensinar que "podemos defini-lo como o conjunto de prerrogativas que a lei reconhece a todo criador intelectual sobre as produções literárias, artísticas ou científicas, de alguma originalidade: de ordem extrapecuniária, em princípio, sem limitação de tempo; e de ordem patrimonial, ao autor, durante toda a sua vida, com acréscimo, para os sucessores indicados na lei, do prazo por ela fixado" ${ }^{, 70}$.

A definição acima é ampla porque faz referência a, além da autoria em si, outros aspectos importantes, como a necessidade de que a obra tenha alguma originalidade e a existência de direitos morais e patrimoniais, bem como o tempo de duração.

A autoria é ínsita ao ser humano, independentemente de sua idade ou condições mentais, sendo produto de sua criatividade. Mesmo que singela, a obra por ele criada e exteriorizada, desde que dotada de alguma originalidade, será objeto de proteção do direito de autor.

Os direitos dos autores são morais ou patrimoniais. Direitos morais são aqueles ligados à personalidade do criador, ao seu íntimo, como o direito de paternidade, de inédito, de integridade, de modificabilidade, de arrependimento, entre outros. Já os direitos

\footnotetext{
${ }^{69}$ BITTAR, Carlos Alberto. Direito de autor, p. 8.

${ }^{70}$ CHAVES, Antônio. Direito de autor: princípios fundamentais, p. 17.
} 
patrimoniais são aqueles de caráter pecuniário, que podem ser traduzidos economicamente por sua utilização pelo próprio autor ou mediante sua autorização.

No âmbito internacional, duas Convenções disciplinam o direito de autor: A Convenção de Berna, de 09-09-1886, e a Convenção Universal de Genebra, da UNESCO, de 06-09-1952. Na seara nacional, o direito de autor é protegido constitucionalmente nos incisos XXVII e XXVIII, do artigo $5^{\circ}$ :

"XXVII - aos autores pertence o direito exclusivo de utilização, publicação ou reprodução de suas obras, transmissível aos herdeiros pelo tempo que a lei fixar;

XXVIII - são assegurados, nos termos da lei:

a) a proteção às participações individuais em obras coletivas e à reprodução da imagem e voz humanas, inclusive nas atividades desportivas;

b) o direito de fiscalização do aproveitamento econômico das obras que criarem ou de que participarem aos criadores, aos intérpretes $e$ às respectivas representações sindicais $e$ associativas."

Em nível infraconstitucional a Lei de Direitos Autorais é a de número 9.610/98, de 19-02-1998, que disciplina sobre o direito de autor e conexos.

Seção II. Direitos da personalidade

Os direitos da personalidade protegem os valores intrínsecos ao ser humano, inerentes a qualquer pessoa e sem os quais não há condições de uma vida digna, acima da mera existência. Como definição de tais direitos pode ser lembrada a lição de Rubens Limongi França, segundo o qual "Direitos da Personalidade dizem-se as faculdades jurídicas cujo objeto são os diversos aspectos da própria pessoa do sujeito, bem assim suas emanações e prolongamentos", 11 .

\footnotetext{
${ }^{71}$ FRANÇA, Rubens Limongi. Manual de Direito Civil, v. 1, p. 403.
} 
De acordo com a corrente naturalista, os direitos da personalidade independem de construção legal para que existam. São inatos ao ser humano, sendo possível dizer que são anteriores ao Estado. Ao direito positivo restaria apenas a função de reconhecer-lhes a existência.

Já para a corrente positivista, os direitos da personalidade derivam do direito positivo. Esse é o entendimento de Adriano De Cupis, que ensina que

não pode hoje se falar mais de direitos inatos, como de direitos respeitantes racionalmente ao homem, devido à sua simples qualidade humana; considerados do ângulo visual do direito positivo, eles não podem constituir mais do que simples exigência de ordem ética. ${ }^{72}$

Os direitos da personalidade foram classificados pelo Prof. Rubens Limongi França, inicialmente, em três categorias: direito à integridade física, moral e intelectual ${ }^{73}$. Alguns anos depois, o citado jurista, verificando que os direitos da personalidade eram muito complexos, propôs quatro critérios para sua classificação: a) o da extensão; b) o da

\footnotetext{
${ }^{72}$ DE CUPIS, Adriano. Os direitos da personalidade, p. 26.

${ }^{73}$ FRANÇA, Rubens Limongi. Manual de Direito Civil, v. 1, p. 411-412. O rol completo é o seguinte: “I) DIREITO À INTEGRIDADE FÍSICA.

1) Direito à Vida e aos Alimentos.

2) Direito sôbre o Próprio Corpo, Vivo.

3) Direito sôbre o Próprio Corpo, Morto.

4) Direito sôbre o Corpo Alheio, Vivo.

5) Direito sôbre o Corpo Alheio, Morto.

6) Direito sôbre Partes Separadas do Corpo, Vivo.

7) Direito sôbre Partes Separadas do Corpo, Morto.

II) DIREITO À INTEGRIDADE INTELECTUAL.

1) Direito à Liberdade de Pensamento.

2) Direito Pessoal de Autor Científico.

3) Direito Pessoal de Autor Artístico.

4) Direito Pessoal de Inventor.

III) DIREITO À INTEGRIDADE MORAL.

1) Direito à Liberdade Civil, Política e Religiosa.

2) Direito à Honra.

3) Direito à Honorificiência.

4) Direito ao Recato.

5) Direito ao Segrêdo Pessoal, Doméstico e Profissional.

6) Direito à Imagem.

7) Direito à Identidade Pessoal, Familiar e Social".
} 
esfera do direito; c) o dos aspectos fundamentais da personalidade e d) o do estado ${ }^{74}$. Tal classificação foi feita em estudo publicado na Revista dos Tribunais.

Ao analisar os ensinamentos de Rubens Limongi França e de Carlos Alberto Bittar, Silmara Juny Chinellato ${ }^{75}$ defende que o direito à vida deve ser incluído de forma separada na classificação sobre os direitos da personalidade, já que é o direito primeiro, condicionante. Sem a vida não se poderia pensar na existência de outros direitos, pois todos os demais dela dependem.

Os direitos da personalidade têm por características a irrenunciabilidade, a imprescritibilidade, a inalienabilidade e a vitaliciedade. Há, também, direitos da personalidade que são mais que vitalícios, sendo perpétuos. Como exemplo de direito da personalidade com a característica da perpetuidade pode ser lembrado o direito autoral de paternidade que, mesmo com a morte do criador, deve sua autoria sempre ser vinculada à obra e, caso haja violação a esse direito, poderá ela ser repelida pelos sucessores do autor ou pelo Ministério Público, por meio da Ação Civil Pública, caso a obra tenha caído em domínio público.

Esses direitos, independentemente de serem especificados na legislação, encontram seu respaldo maior no princípio da dignidade da pessoa humana, que está previsto no art. $1^{\circ}$, inciso III, da Constituição Federal, como um dos fundamentos da República Federativa do Brasil.

Os direitos aqui discutidos vêm protegidos pela Constituição Federal de 1988 no artigo $5^{\circ}$ que, no rol dos seus setenta e oito incisos protege, entre outros: a liberdade de manifestação de pensamento (inciso IV), a indenização por dano moral, material ou à imagem (inciso V), a liberdade de expressão da atividade intelectual, artística, científica e de comunicação, independentemente de censura ou licença (inciso IX), a liberdade a inviolabilidade da intimidade, da vida privada, da honra e da imagem das pessoas, assegurado o direito à indenização pelo dano material ou moral decorrente da sua violação (inciso $\mathrm{X}$ ).

\footnotetext{
${ }^{74}$ FRANÇA, Rubens Limongi. Direitos da personalidade: coordenadas fundamentais, p. 13.

${ }^{75}$ CHINELLATO, Silmara Juny. Arts. $1^{\circ}$ a 21 , p. 18.
} 
Também o Código Civil atual (Lei 10.406, de 10 de janeiro de 2002) disciplina os direitos da personalidade nos arts. 11 a 21 de sua Parte Geral, Capítulo II, Título I, do Livro I. Embora não trate de todos os direitos da personalidade, dispõe sobre vários aspectos relevantes, como sua intransmissibilidade e irrenunciabilidade (art. 11), a possibilidade de a pessoa exigir a cessação da ameaça ou da lesão a direito da personalidade e reclamar perdas e danos (art. 12), direito ao próprio corpo (arts. 13 a 15), direito ao nome (arts. 16 a 19), direito à imagem (art. 20) e a inviolabilidade da vida privada (art. 21).

$\S 1^{\circ}$ Imagem

Embora tenha muitos significados ${ }^{76}$, o termo imagem, no aspecto jurídico, apresenta sentido devidamente delineado, estando incluído entre os direitos da personalidade.

${ }^{76}$ De acordo com o Dicionário AURÉLIO (Novo dicionário Aurélio da língua portuguesa, p. 917-918), imagem é assim definida: "imagem. [Do lat. imagine.] S. f. 1. Representação gráfica, plástica ou fotográfica de pessoa ou de objeto. 2. Restr. Representação plástica da Divindade, de um santo, etc.: "Trouxeram uma pequena mesa que puseram ao lado do leito com uma grande i m a g e m de Cristo" (L. Lavenère, O Padre Cornélio, p. 95). [Cf. ídolo (1) e ícone.] 3. Restr. Estampa, geralmente pequena, que representa um assunto ou motivo religioso. 4. Fig. Pessoa muito formosa. 5. Reprodução invertida, de pessoa ou de objeto, numa superfície refletora ou refletidora: Passou alguns minutos olhando a própria i m a g e m nas águas do lago. 6. Representação dinâmica, cinematográfica ou televisionada, de pessoa, animal, objeto, cena, etc. 7. Representação exata ou analógica de um ser, de uma coisa; cópia: $O$ pequeno é a $i$ $m$ a g e $m$ do pai; A nova cidade era uma i m a g e m exata da outra, destruída pelo terremoto. 8. Aquilo que evoca uma determinada coisa, por ter com ela semelhança ou relação simbólica; símbolo: Para aquele moralista, a transformação dos costumes é a i m a g e $m$ da decadência; Dizem que o azul é a i m a g e $m$ da tranqüilidade. 9. Representação mental de um objeto, de uma impressão, etc.; lembrança, recordação: $i$ m a g e $n$ s do passado. 10. Produto da imaginação, consciente ou inconsciente; visão: Eram seus sonhos povoados de i m a g e $n$ s aterradoras. 11. Manifestação sensível do abstrato ou do invisível: Em "O Alienista", Machado de Assis nos dá boa i m a g e m de sal mordacidade. 12. Metáfora: $i$ m a g e m gasta, banal. 13. Álg. Mod. Ponto de um conjunto que corresponde a um ponto de outro numa aplicação deste sobre aquele. 14. Ópt. Conjunto de pontos no espaço, para onde convergem, ou de onde divergem, os raios luminosos que, originados de um objeto luminoso ou iluminado, passam através de um sistema óptico. 15. Rel. Públ. Conceito genérico resultante de todas as experiências, impressões, posições e sentimentos que as pessoas apresentam em relação a uma empresa, produto, personalidade, etc. ...".

Já para HOUAISS (Dicionário Houaiss da língua portuguesa, p. 1573), a palavra imagem é assim definida: "imagem s.f. (sXIII cf. FichIVPM) 1 representação da forma ou do aspecto de ser ou objeto por meios artísticos $<i$. desenhada, gravada, pintada, esculpida $\mathbf{1 . 1}$ representação de seres que são objeto de culto, de veneração $\langle a i$. de Cristo $\rangle\langle u m a i$. de São Francisco $>1.2$ estampa, sem caráter de obra original ou rara, que reproduz temas diversos ou, mais esp., motivos religiosos <um álbum de i.> <algumas i. marcavam as páginas do missal> $\mathbf{2}$ aspecto particular pelo qual um ser ou um objeto é percebido; cena, quadro <imagens da rua $><$. urbana $>3$ reprodução invertida de um ser ou de um objeto, transmitida por uma superfície refletora 4 reprodução estática ou dinâmica de seres, objetos, cenas etc. obtida por meios técnicos $<i$. fotográfica $><$. televisada $><$. magnética $>\mathbf{5}$ fig. pessoa muito bonita; cromo $\mathbf{6}$ fig. aquilo que apresenta uma relação de analogia, de semelhança (simbólica ou real); réplica, retrato, reflexo <ela é a $i$. do pai > <a casa era a $i$. da dona 7 fig. pessoa que representa, simboliza ou faz lembrar alguma coisa abstrata; personificação <ela era a própria $i$. da tristeza e solidão $><$ rapaz é a $i$. da saúde $>\mathbf{8}$ fig. opinião (contra ou a favor) que o público pode ter de uma instituição, organização, personalidade de renome, marca, produto etc.; conceito que uma pessoa goza junto a outrem $<$ um político precisa cuidar de sua $i .><$ teve a $i$. abalada pelo escândalo $>9$ LIT qualquer maneira particular de expressão literária eu tem por efeito substituir a representação precisa de um fato, situação etc. por uma alegoria, visão, evocação etc. $<i$. bíblicas $><i$. camonianas $><i$. vulgares $>10$ MAT elemento determinado pela aplicação de uma função em um determinado ponto $\mathbf{1 1}$ ÓPT representação de um objeto que emite ou recebe luz e que é formada por raios luminosos que passam por uma lente, espelho ou qualquer outro sistema óptico 12 PSIC representação ou reprodução mental de uma percepção ou sensação anteriormente experimentada $<i$. visual, olfativa $>13$ PSIC representação mental de um ser imaginário, um princípio ou uma abstração <a i. do demônio, da realeza, da democracia, do círculo> ..." 
Conforme o ensinamento de Carlos Alberto Bittar, o direito à imagem "consiste no direito que a pessoa tem sobre a sua forma plástica e respectivos componentes distintos (rosto, olhos, perfil, busto) que a individualizam no seio da coletividade."77.

Além de ser um direito da personalidade, o direito à imagem tem inegáveis reflexos patrimoniais, já que pode ser objeto de negociação e valoração pecuniária, bastando lembrar as altas cifras que costumam atingir os contratos que versem sobre direito à imagem de modelos, atores e esportistas. Como exemplo, vale mencionar que, em nível internacional, comenta-se que a atriz Nicole Kidman teria recebido vários milhões de dólares para protagonizar obra publicitárias do perfume Chanel 5.

A veiculação da imagem de uma pessoa deve ser precedida de autorização; se esta não existir, haverá violação do direito à imagem causando danos morais ou patrimoniais ao seu titular. Aos responsáveis restará condenação, compensando aqueles ou indenizando estes. Na ocorrência de ambos os danos, a condenação cumulará a compensação e a indenização.

O direito à imagem está protegido constitucionalmente em dois incisos do artigo $5^{\circ}$ :

" $V$ - é assegurado o direito de resposta, proporcional ao agravo, além da indenização por dano material, moral ou à imagem;

$X$ - são invioláveis a intimidade, a vida privada, a honra e a imagem das pessoas, assegurado o direito a indenização pelo dano material ou moral decorrente de sua violação".

Como a palavra "imagem" está repetida em dois incisos, Luiz Alberto David Araújo chegou à interessante conclusão de que o direito à imagem concebido constitucionalmente abrange dois aspectos, a que chamou de imagem-retrato (inciso $\mathrm{X}$ ) e imagem-atributo (inciso V), sendo aquela a reprodução dos aspectos físicos da pessoa, enquanto esta é a identificação do perfil público que a pessoa opta em construir ${ }^{78}$.

\footnotetext{
${ }^{77}$ BITTAR, Carlos Alberto. Os direitos da personalidade, p. 94.

${ }^{78}$ ARAUJO, Luiz Alberto David. A proteção constitucional da própria imagem.
} 
O Código Civil, em seu artigo 20, dispõe sobre o direito à imagem da seguinte forma:

“Art. 20. Salvo se autorizadas, ou se necessárias à administração da justiça ou à manutenção da ordem pública, a divulgação de escritos, a transmissão da palavra, ou a publicação, a exposição ou a utilização da imagem de uma pessoa poderão ser proibidas, a seu requerimento e sem prejuízo da indenização que couber, se lhe atingirem a honra, a boa fama ou a respeitabilidade, ou se se destinarem a fins comerciais."

O citado artigo do Código Civil versa apenas sobre a imagem-retrato, recebendo crítica de Luiz Alberto David Araújo por ser acanhado, deixando de seguir a Constituição Federal, que também se refere à imagem-atributo ${ }^{79}$.

O direito à imagem sofre limitações baseadas no interesse público, que prevalece sobre o privado. É o caso, por exemplo, de pessoa que contraia doença séria, até então desconhecida, caracterizada por manchas e feridas no corpo. Nessa hipótese, é lícita a divulgação de fotografia do doente, em campanhas que alertem a população para que pessoas que apresentem os sintomas mostrados se dirijam, com urgência, a hospitais.

É admissível, também, que o direito à imagem de governantes, políticos, artistas e esportista receba limitações diante do direito de informar que têm os veículos de imprensa. No tocante a governantes e políticos, a necessidade da divulgação de seus atos explica a atenuação do direito à imagem, pois é de interesse geral que os atos por aqueles praticados sejam divulgados. Some-se a isso, o argumento de que governantes e políticos, pela própria natureza de sua esfera de atuação, submetem-se voluntariamente à análise de seus atos pela população, não podendo colocar óbices à divulgação de notícias a eles relativas. Já no concernente a artistas e esportistas, o direito de imagem recebe limitação pelo fato de serem pessoas cujas atividades podem ter como público um grande número de pessoas,

79 ARAUJO, Luiz Alberto David. O conteúdo do direito à própria imagem: um exercício de aplicação do critérios de efetivação constitucional, p. 126. 
como ocorre com jogadores de futebol e atores de telenovelas. Vale lembrar que esportistas e artistas, direta ou indiretamente, exercem um papel de formadores de opinião e, por isso, seus atos alcançam maior repercussão.

Outro exemplo em que prevalece o direito de informar está na hipótese de alguém que participa de passeata por ocasião de greve de trabalhadores. Não poderá essa pessoa alegar que teve sua imagem violada, ficando em situação constrangedora frente a seu empregador. Nada poderá por ela ser requerido como compensação por danos morais, nem mesmo poderá exigir a cessação da divulgação da fotografia ou filmagem, pois referentes a evento público do qual participou efetivamente. Lembra-se, ainda, a licitude de uma pessoa ter sua imagem divulgada, ainda que em trajes sumários, por estar participando de desfile carnavalesco.

Vê-se, portanto, que não há qualquer ofensa à imagem ou privacidade se alguém é fotografado ou filmado participando de evento público relevante, por fazer parte da notícia ${ }^{80}$. Também não poderá se insurgir contra a divulgação aquele que voluntariamente se expõe às câmeras, o exibicionista.

$\S 2^{\circ} \mathrm{Voz}$

Questão interessante é a relativa à existência do direito à voz como parte do direito à imagem ou como modalidade autônoma dos direitos da personalidade. Antes, porém, de abordar o tema, vale destacar a importância da voz como um elemento físico identificador do ser humano, já que é distinta em cada pessoa, da mesma forma como a impressão digital. Também é válido lembrar que apenas o ser humano tem voz, já que os sons produzidos pelos animais não são como tal considerados.

A voz humana exerce papel destacado nas relações sociais. Claros exemplos disso são dados por Pablo Stolze Gagliano e Rodolfo Pamplona Filho ${ }^{81}$ que, ao versarem sobre o

80 “DIREITO CIVIL. DIREITO DE IMAGEM. TOPLESS PRATICADO EM CENÁRIO PÚBLICO.

Não se pode cometer o delírio de, em nome do direito de privacidade, estabelecer-se uma redoma protetora em torno de uma pessoa para torná-la imune de qualquer veiculação atinente à sua imagem. Se a demandante expõe sua imagem em cenário público, não é ilícita ou indevida sua reprodução pela imprensa, uma vez que a proteção à privacidade encontra limite na própria exposição realizada.

Recurso especial não conhecido."

(REsp 595600 - SC, Quarta Turma, Rel. Min. Cesar Asfor Rocha, j. 18-03-2004)

${ }^{81}$ GAGLIANO, Pablo Stolze; PAMPLONA FILHO, Rodolfo. Novo curso de direito civil: parte geral, p. 164. 
assunto, referem-se ao Lombardi, conhecido assistente do apresentador Sílvio Santos, e as vozes de personagens de desenhos animados. Os exemplos são adequados, por se tratar de vozes muito conhecidas e que permitem a quem as escuta imediatamente identificar seus possuidores, embora estes não tenham sua imagem física divulgada. Poucos conhecem o Lombardi, mas muitos identificam que é ele quem está falando com Silvio Santos. Da mesma forma, muitas pessoas, mesmo sem ver o personagem de desenho, sabem, apenas ao ouvirem sua voz, quem está falando.

É muito grande a relevância de vozes bem características para o sucesso de obras que tenham um conteúdo sonoro. O que dizer de programas de rádio ou de televisão sem as vozes de seus protagonistas? Nos desenhos animados, que ganham espaço importante no mercado cinematográfico, têm sido comum a utilização de atores famosos como dubladores. Tanto nos Estados Unidos da América do Norte como no Brasil, é amplamente divulgada a participação de famosos em dublagens, sendo esse fato útil para a promoção e sucesso das obras.

Vale destacar o caso dos dubladores norte-americanos do desenho Os Simpsons que, após anos de trabalho vinculados aos personagens, no início do mês de abril de 2004, decidiram fazer greve pleiteando melhor remuneração. O movimento grevista durou um mês e foi bem sucedido, alcançando a majoração nos pagamentos pela dublagem (cujos valores não foram divulgados), por não se duvidar que o desenho restaria bastante prejudicado com uma mudança nas vozes já tão conhecidas e incorporadas no perfil dos personagens.

Pontes de Miranda entende que a voz está contida no âmbito do direito à imagem ${ }^{82}$, não sendo um direito autônomo. No mesmo sentido é a lição de Regina Sahm ${ }^{83}$, Luiz Alberto David Araújo ${ }^{84}$ e Santos Cifuentes ${ }^{85}$.

Carlos Alberto Bittar, tratando do direito à voz em um capítulo específico de seu livro Os direitos da personalidade, ensina que

\footnotetext{
${ }^{82}$ PONTES DE MIRANDA, Francisco Cavalcanti. Tratado de direito privado, tomo VII, p. 53.

${ }^{83}$ SAHM, Regina. Direito à imagem no direito civil contemporâneo: de acordo com o novo Código Civil, Lei n. 10.406, de 10-1-2002, p. 19.

${ }^{84}$ ARAÚJO, Luiz Alberto David. A proteção constitucional da própria imagem, p. 29.

${ }^{85}$ CIFUENTES, Santos. Derechos personalísimos, p. 518.
} 
embora componente físico - e como tal integrante do conjunto da imagem da pessoa - destacou-se para ganhar individualidade, frente ao uso isolado, principalmente em rádio e em gravações, identificando pessoas e estilos vários. Possibilita seja a pessoa mentalmente visualizada por associação, perenizando-se pela fixação. ${ }^{86}$

Também entendem o direito à voz como autônomo Silmara Juny Chinellato ${ }^{87}$, Carlos Roberto Gonçalves ${ }^{88}$ e Roxana Cardoso Brasileiro Borges ${ }^{89}$.

Com a promulgação da Constituição Federal de 1988, o direito à voz foi expressamente protegido no artigo $5^{\circ}$, inciso XXVIII, alínea $a$, nos seguintes termos:

“XXVIII - São assegurados, nos termos da lei:

a) a proteção às participações individuais em obras coletivas e à reprodução da imagem e voz humanas, inclusive nas atividades desportivas"

Assim, como a imagem e a voz humanas foram indicadas separadamente, são direitos distintos, embora ambas se refiram à identificação do ser humano. Este entendimento ganhou mais força com o advento do Código Civil de 2002, que em seu artigo 20 , dispõe que

"salvo se autorizadas, ou se necessárias à administração da justiça ou à manutenção da ordem pública, a divulgação de escritos, a transmissão da palavra, ou a publicação, a exposição ou a utilização da imagem de uma pessoa poderão ser proibidas, a seu requerimento e sem prejuízo da indenização que couber, se lhe atingirem a honra, a boa fama ou a respeitabilidade, ou se se destinarem a fins comerciais."

\footnotetext{
${ }^{86}$ BITTAR, Carlos Alberto. Os direitos da personalidade, p. 103.

${ }^{87}$ CHINELLATO, Silmara Juny. Arts. $1^{\circ}$ a 21 , p. 18.

${ }^{88}$ GONÇALVES, Carlos Roberto. Direito civil brasileiro, p. 171.

${ }^{89}$ BORGES, Roxana Cardoso Brasileiro. Dos direitos da personalidade, p. 268.
} 
Antonio Carlos Morato explica que "apesar de não mencionado expressamente, o direito à voz encontra-se implícito no art. 20, por meio da expressão transmissão da palavra" ${ }^{90}$, entendimento também abraçado por Carlos Roberto Gonçalves ${ }^{91}$.

$\S 3^{\circ}$ Honra

Nas palavras de Adriano De Cupis, pode-se entender como honra "tanto o valor moral íntimo do homem, como a estima dos outros, ou a consideração social, o bom nome ou a boa fama, como enfim, o sentimento, ou consciência, da própria dignidade pessoal"92. Já para Aparecida Amarante, que adota a conceituação acima citada, "a honra encerra o respeito e consideração social aliados ao sentimento ou consciência da própria dignidade",93.

A honra se divide em subjetiva e objetiva. Aquela, de uma maneira geral, pode ser entendida como o conceito que a pessoa tem de si própria, enquanto esta é o conceito que a sociedade tem da pessoa, ou seja, sua reputação ou boa fama.

O direito à honra, assim como o direito à imagem, recebe proteção constitucional no art. $5^{\circ}$, inciso $\mathrm{X}$, assim redigido: " $X$ - são invioláveis a intimidade, a vida privada, a honra e a imagem das pessoas, assegurado o direito a indenização pelo dano material ou moral decorrente de sua violação".

Os dois institutos são tão próximos um ao outro que, na lição de Aparecida Amarante, “... sem dúvida, em muitos casos, onde se discute o direito à imagem, refletem situações de propagação da imagem em circunstâncias que caracterizam uma ofensa à honra"94.

\footnotetext{
${ }^{90}$ MORATO, Antonio Carlos. Direito à voz: reflexões sobre sua proteção no âmbito da sociedade da informação, p. 164.

${ }^{91}$ GONÇALVES, Carlos Roberto. Direito civil brasileiro, p. 169.

${ }^{92}$ DE CUPIS, Adriano. Os direitos da personalidade, p. 121.

${ }^{93}$ AMARANTE, Aparecida I. Responsabilidade civil por dano à honra, p. 41.

${ }^{94}$ AMARANTE, Aparecida I. Responsabilidade civil por dano à honra, p. 83.
} 


\title{
CAPÍTULO 2. AS PRINCIPAIS MANIFESTAÇÕES HUMORÍSTICAS E SUAS IMPLICAÇÕES JURÍDICAS
}

\author{
Seção I. Paródia
}

A paródia tem grande relevância, pois é considerada como uma das limitações ao direito de autor.

O Código Civil de 1916 não fazia referência à paródia, dispondo, apenas, no parágrafo único do artigo 665, que "são livres as paráfrases, que não forem verdadeira reprodução da obra original". Vale destacar, porém, que, segundo informou João Luiz Alves, no Projeto da Câmara o que constava era a palavra "paródias", tendo ela sido alterada na redação final para a palavra "paráfrases", atendendo-se à crítica feita por Rui Barbosa, que defendia que era sobre as paráfrases que se pretendia legislar, e não sobre as paródias, que nem mereceriam inclusão no Código Civi1 ${ }^{95}$.

João Luiz Alves, embora ressaltasse que entendia que o Projeto da Câmara versava, sim, sobre as paródias, concluiu que a interpretação do artigo 665 deveria respeitar a literalidade do texto. Entretanto, o citado jurista ressalvou que as paródias mantinham-se lícitas $^{96}$.

Apesar de não constar no texto legal, Carvalho Santos entendia que a paródia era permitida, explicando ser ela uma criação nova com inspiração diversa e sem intenção de fazer concorrência ao autor. A paródia representaria até mesmo uma vantagem para a obra imitada, eis que serviria como uma forma de propaganda. Assim, "a paródia não prejudica a quem quer que seja, não se justificando, portanto, seja ela proibida ou se exija a autorização do autor da obra parodiada" ${ }^{97}$.

Já a Lei 5.988/73, que revogou as disposições do Código Civil de 1916 relativas à propriedade literária, artística e científica, inovou ao ampliar a dicção legal até então existente para dispor no artigo 50 que "são livres as paráfrases e paródias que não forem

\footnotetext{
95 ALVES, João Luiz. Código civil anotado, p. 146-147.

${ }^{96}$ ALVES, João Luiz. Código civil anotado, p. 147.

${ }^{97}$ CARVALHO SANTOS, João Manuel. Código civil brasileiro interpretado: principalmente do ponto de vista prático, p. 466.
} 
verdadeiras reproduções da obra originária, nem lhe implicarem descrédito". Assim, a partir da Lei 5.988/73, a paródia expressamente passou a ser livre, tornando-se uma limitação ao direito de autor.

Idêntica redação foi dada ao artigo 47 da Lei 9.610/98, que derrogou a Lei 5.988/73. Assim, desde 1973, a legislação pátria passou a referir-se a duas figuras específicas: paráfrases e paródias.

Vale ressaltar que a paródia, embora seja considerada uma limitação ao direito de autor, está prevista fora do artigo 46 da Lei $9.610 / 98^{98}$, que é aquele que trata do rol dessas limitações. Destaque-se que sobre a utilização de outro artigo para tratar da paródia (e também da paráfrase) continua pertinente a observação feita por Newton Paulo Teixeira dos Santos, que se referia ao artigo 50 da Lei 5988/73, destacando que "nada justifica que a exceção contida no art. 50 escape da relação prevista no art. 49. Somente por capricho do legislador ela foi destacada, devendo por isso, ser incorporada ao referido art. 49, por

\footnotetext{
98 “Art. 46. Não constitui ofensa aos direitos autorais:

I- a reprodução:

a) na imprensa diária ou periódica, de notícia ou de artigo informativo, publicado em diários ou periódicos, com a menção do nome do autor, se assinados, e da publicação de onde foram transcritos;

b) em diários ou periódicos, de discursos pronunciados em reuniões públicas de qualquer natureza;

c) de retratos, ou de outra forma de representação da imagem, feitos sob encomenda, quando realizada pelo proprietário do objeto encomendado, não havendo a oposição da pessoa neles representada ou de seus herdeiros;

d) de obras literárias, artísticas ou científicas, para uso exclusivo de deficientes visuais, sempre que a reprodução, sem fins comerciais, seja feita mediante o sistema braile ou outro procedimento em qualquer suporte para esses destinatários;

II - a reprodução, em um só exemplar de pequenos trechos, para uso privado do copista, desde que feita por este, sem intuito de lucro;

III - a citação em livros, jornais, revistas ou qualquer outro meio de comunicação, de passagens de qualquer obra, para fins de estudo, crítica ou polêmica, na medida justificada para o fim a atingir, indicando-se o nome do autor e a origem da obra;

IV - o apanhado de lições em estabelecimentos de ensino por aquelas a quem elas se dirigem, vedada sua publicação, integral ou parcial, sem autorização prévia e expressa de quem as ministrou;

$V-a$ utilização de obras literárias, artísticas ou científicas, fonogramas e transmissão de rádio e televisão em estabelecimentos comerciais, exclusivamente para demonstração à clientela, desde que esses estabelecimentos comercializem os suportes ou equipamentos que permitam a sua utilização;

$V I$ - a representação teatral e a execução musical, quando realizada no recesso familiar ou para fins exclusivamente didáticos, nos estabelecimentos de ensino, não havendo em qualquer caso intuito de lucro; VII - a utilização de obras literárias, artísticas ou científicas para reproduzir prova judiciária ou administrativa;

VIII - a reprodução, em quaisquer obras, de pequenos trechos de obras preexistentes, de qualquer natureza, ou de obra integral, quando de artes plásticas, sempre que a reprodução em si não seja o objetivo principal da obra nova e não prejudique a exploração normal da obra reproduzida nem cause um prejuízo injustificado aos legítimos interesses dos autores".
} 
simples questão de técnica legislativa" ${ }^{99}$. Na legislação atual, nada impediria que o teor do artigo 47 estivesse contido no artigo anterior.

Antes da análise da paródia na Lei 9.610/98, é necessário fazer uma rápida abordagem sobre a paráfrase que, conforme definição de AURÉLIO, é o "desenvolvimento do texto de um livro ou de um documento conservando-se as idéias originais"100. HOUAISS informa que ela "é a explicação ou a interpretação de um texto com outras palavras" $"$. Vale, também, registrar o ensinamento de Affonso Romano de Sant'Anna no sentido de que não há uma história para o referido termo (para-phrasis), que desde o grego tinha o sentido de repetição de uma sentença; isso é por ele explicado porque a história não valoriza o que é mera repetição, interessando-se apenas pelo que é novo, pelo que se configura como um acréscimo ${ }^{102}$.

O parafraseador reafirma a idéia expressada pelo criador da obra utilizada, porém com nova linguagem. Não existe, pois, uma negação, mas, sim, uma confirmação. Nota-se que o direito de autor, no tocante à paráfrase, não se afasta do exato conceito que tem esta figura.

Embora o artigo 47 da Lei 9.610/98 não esclareça o que é paródia e apenas delimite que ela não pode ser mera reprodução da obra originária e nem pode causar-lhe

\footnotetext{
${ }^{99}$ SANTOS, Newton Paulo Teixeira dos. Paráfrase, paródia e direito autoral, p. 11.

${ }^{100}$ O texto completo do verbete é: "paráfrase. [Do gr. paráphrasis, pelo lat. paraphrase.] S. f. 1. Desenvolvimento do texto de um livro ou de um documento conservando-se as idéias originais; metáfrase. 2. Tradução livre ou desenvolvida. 3. Fam. Comentário malevolente." (Novo dicionário Aurélio da língua portuguesa, $\mathrm{p}$ 1266).

${ }^{101}$ Para o verbete são registrados os seguintes sentidos: "paráfrase s.f. (1720 cf. RB) 1 LIT interpretação ou tradução em que o autor procura seguir mais o sentido do texto que a sua letra; metáfrase $\mathbf{2}$ LIT interpretação, explicação ou nova apresentação de um texto (entrecho, obra etc.) que visa torná-lo mais inteligível ou que sugere novo enforque para o seu sentido $\mathbf{2 . 1} \mathrm{pej}$. trabalho desse gênero cujo texto, prolixo e supérfluo, só faz diluir o conteúdo do texto sobre que versa 3 PED uso de paráfrase (acp. 1) no estudo de um texto ou no ensino de composição literária 4 LIT versão versejada de um original em prosa, sem preocupação de perfeita equivalência 5 LIT versão, ger. em verso, de passagem da Bíblia, cujo tema o autor desenvolve 6 p.ext.pej. narração ou discurso prolixo, verboso, supérfluo 7 p.ext.infrm. interpretação ou comentário desfavorável, maldoso 8 LING maneira diferente de dizer algo que foi dito; frase sinônima de outra 9 MÚS técnica de contraponto dos SXV e XVI em que uma voz (ou mais) fazia citações de uma melodia de cantochão 10 MÚS transformação de uma melodia a partir de um tema (p.ex., litúrgico) $<p$. para órgão de Bach> 11 MÚS fantasia de complexidade virtuosística para o executante composta sobre melodia ou obra preexistente <as $p$. de Liszt sobre óperas italianas> ..." (Dicionário Houaiss da língua portuguesa, p. 2127).

${ }^{102}$ SANT'ANNA, Affonso Romano de. Paródia, paráfrase \& cia, p. 17.
} 
descrédito $^{103}$, é muito importante que essa criação intelectual seja definida doutrinariamente.

Da própria leitura do artigo 47 conclui-se que a paródia é uma "obra derivada", pois a redação do texto legal expressamente refere-se à vedação que esta seja verdadeira reprodução da "obra originária".

A obra derivada, conforme o disposto no artigo $5^{\circ}$, VIII, g, da Lei de Direitos Autorais, é "a que, constituindo criação intelectual nova, resulta da transformação de obra originária". Assim, a obra derivada é a recriação da obra originária (também chamada de primígena), ou seja, ela tem como ponto de partida uma obra preexistente e, por apresentar originalidade, altera essa criação anterior, constituindo-se em um novo trabalho artístico, literário ou científico.

Vale destacar, porém, que esse tema é controverso, pois existe entendimento no sentido de que a paródia não é obra derivada. Nesse sentido, leciona Eduardo Vieira Manso, analisando a Lei 5.988/73, que

a paródia, por ser antítese da obra anterior, não é obra derivada, no sentido técnico da expressão: obra derivada é aquela que, “constituindo criação autônoma, resulta da adaptação da obra originária" (de acordo com definição da letra "g" do inciso VI do art. $4^{\text {o }}$ da Lei n. 5.998/73, em que pesem os defeitos dessa definição). ${ }^{104}$

Essa posição é compartilhada por José de Oliveira Ascensão, segundo o qual “a obra anterior dá só o tema, mas a paródia faz uma criação peça por peça de que resulta um novo conjunto; por isso se fala no tratamento antitético do tema"105.

Na Itália, defendendo a tese de que a paródia não é obra derivada. Alfredo Arienzo sustenta que o caráter antitético da obra ora em comento confere-lhe autonomia, pois a

\footnotetext{
103 “Art. 47. São livres as paráfrases e paródias que não forem verdadeiras reproduções da obra originária nem lhe implicarem descrédito".

${ }^{104}$ MANSO, Eduardo Vieira. Direito autoral, p. 332-333.

${ }^{105}$ ASCENSÃO, José de Oliveira. Direito autoral, p. 66.
} 
individualidade do criador parodiado, ínsita à sua obra, não está presente na paródia, que exprime a individualidade do parodiador $^{106}$.

Analisando a legislação espanhola, que inclui as paródias entre as limitações ao direito de autor ${ }^{107}$, Rafael Sánchez Aristi conclui que não se trata de obra derivada porque, se assim o fosse, seria exigida a autorização do autor parodiado; como essa autorização não é necessária, por uma questão lógica, não há que se falar em obra derivada ${ }^{108}$, entendimento este também abraçado por Isabel Espín Alba ${ }^{109}$.

Embora o posicionamento no sentido de que a paródia é criação originária seja merecedor de todo respeito, não é ele o melhor e não responde a uma questão: por que uma recriação de um romance sério para a forma de romance de ficção científica ou de terror é obra derivada mas, por outro lado, uma recriação cômica dessa mesma obra não recebe igual tratamento legal? Como justificar que, pelo simples fato de se tratar de criação humorística que, como qualquer obra derivada, desenvolve um trabalho a partir de uma criação preexistente, ela não deveria submeter-se às mesmas conseqüências legais das outras obras derivadas?

A paródia é obra derivada como todas aquelas que signifiquem uma transformação da criação primígena. O caráter antitético da paródia, por si só, não tem o condão de tornála criação autônoma; o que explica o dispositivo legal é a opção do legislador por maior liberdade para a criação humorística. Se apenas o efeito de antítese caracterizasse a paródia, então a imitação de uma criação transformando-a de cômica para séria (ou, ainda, de séria para suspense, terror ou ficção científica, por exemplo) também seria paródia para os efeitos do artigo 47 da Lei 9.610/98, mas não é isso o que ocorre.

Também o fato de o legislador optar por isentar o autor parodista da necessidade de obter autorização do criador da obra originária não caracteriza, por si só, a paródia como uma obra originária. A paródia, nos termos do artigo 47 da Lei 9.610/98, é obra derivada,

\footnotetext{
${ }^{106}$ ARIENZO, Alfredo. Paródia, p. 448-449.

107 Art. 39 LPI: "no será considerada transformación que exija consentimiento del autor la parodia de la obra divulgada, mientras no implique riesgo de confusión con la misma ni se infiera un daño a la obra original o a su autor ...".

${ }_{108}$ ARISTI, Rafael Sánchez. La propiedad intelectual sobre las obras musicales, p. 556-557.

${ }^{109}$ ALBA, Isabel Espín. La parodia de obras divulgadas, p. 282-283.
} 
mas não se exige a permissão do autor parodiado, já que a lei a inclui entre os limites ao direito de autor.

Vale destacar a lição de Mario Sol Muntañola que, embora se refira ao tratamento legal dado à paródia na legislação espanhola, pode ser aplicada no concernente ao direito brasileiro. Em uma tradução livre, diz ele que

a própria natureza da paródia pede ser ela obra derivada, pois sem a referencia à obra criticada, parodiada, não haveria razão de ser nem tampouco se entenderia sua expressão. Assim, quando a paródia estiver compreendida dentro dos supostos legalmente previstos, por ser lícita, a faculdade de autorizar a transformação que corresponde ao autor da obra parodiada se desativará pela imposição de um limite. ${ }^{110}$

No mesmo sentido acima indicado vai o entendimento de Rodrigo Bercovitz Rodríguez-Cano de que, em tradução livre, "a paródia é também uma obra derivada que não requer autorização do autor da obra parodiada (art. 39 LPI)" $" 111$.

Entre os autores que incluem a paródia entre as obras derivadas podem ser citados Carlos Alberto Bittar ${ }^{112}$, Luiz Gonzaga Silva Adolfo ${ }^{113}$, Eliane Abrão ${ }^{114}$, Delia Lipszyc ${ }^{115}$, Ricardo Antequera Parilli ${ }^{116}$, Giorgio Jarach ${ }^{117}$.

A lei brasileira, como ressaltado, somente admite a paródia se ela não for verdadeira reprodução da obra originária e se não lhe causar descrédito; torna-se necessário, portanto, já que a legislação não o faz suficientemente, procurar explicitar o círculo de abrangência desses requisitos.

\footnotetext{
${ }^{110}$ MUNTAÑOLA, Mario Sol. El régimen jurídico de La parodia, p. 181-182. "La propia naturaleza de la parodia pide ser obra derivada, pues sin la referencia de la obra criticada, parodiada, no tendría razón de ser ni tampoco se entendería su expresión. Así, cuando la parodia pueda concebirse comprendida dentro de los supuestos legalmente previstos - por ser lícita -, la facultad de autorizar la transformación que corresponde al autor de la obra parodiada se desactivará por la imposición de un límite".

${ }^{111}$ RODRÍGUEZ-CANO, Rodrigo Bercovitz. La obra, p. 76. "La parodia es también una obra derivada que no requiere autorización del autor de la obra parodiada (art. 39 LPI)".

${ }^{112}$ BITTAR, Carlos Alberto. Direito de autor, p. 26.

${ }^{113}$ ADOLFO, Luiz Gonzaga Silva. As limitações ao direito de autor na legislação autoral brasileira, p. 38.

${ }^{114}$ ABRÃO, Eliane. Direitos de autor e direitos conexos, p. 152.

${ }^{115}$ LIPSZYC, Delia. Derecho de autor y derechos conexos, p. 118.

${ }_{116}$ PARILLI, Ricardo Antequera. La obra como objecto del derecho de autor, p. 56-57.

${ }^{117}$ JARACH, Giorgio. Manuale del diritto d'autore, p. 313-314.
} 
$\S 1^{\circ}$ Requisitos legais

A) imitação da obra primígena

Partindo-se da idéia adotada por grande parte da doutrina de que, para ser reconhecida como paródia, a obra deve ter cunho humorístico, parece imprescindível que o parodista valha-se do recurso da imitação da obra parodiada para atingir seu objetivo.

Somente haverá paródia se houver, ao mesmo tempo, uma imitação e uma transformação da criação primígena. É nesse jogo de semelhança e dessemelhança que reside o humor. O público receptor da obra, ao constatar a imitação da criação ridicularizada, reprodução essa que não é total, já que contém traços de originalidade, entenderá o objetivo do parodista e, possivelmente, achará engraçada tal obra.

O artigo 47 da Lei 9.610/98, ao dispor que a paródia não pode ser verdadeira reprodução da obra originária, ou seja, a imitação não pode ser total, implicitamente especifica que esse tipo de criação intelectual precisa ser uma imitação parcial da obra parodiada. Embora não esteja expresso no citado artigo, é imprescindível que a paródia seja uma imitação da criação parodiada, já que, sem esta, aquela não existiria. Note-se, portanto, que a imitação da obra primígena não é proibida nesse caso, eis que da essência da paródia.

O que se deve averiguar, e é esse o objetivo do requisito criado pelo artigo 47, é a extensão da imitação feita, isto é, se o parodista utilizou tal recurso apenas o suficiente para alcançar seu resultado ou se exagerou, imitando em demasia e desnecessariamente a obra primígena.

Não há critério exato para identificação do exagero ou não da imitação contida na paródia; essa análise deverá ser feita caso a caso. Tal avaliação, muitas vezes, será extremamente difícil, já que se estará entrando no campo da perquirição de critérios criativos; em outras palavras, tentar-se-á estabelecer qual é o limite da liberdade criativa de um autor, o que é muito subjetivo. 
A necessidade da verificação acima apontada é realmente complexa e perigosa porque, além do risco de configurar uma análise do mérito da obra, o que não é permitido em matéria autoralista, tanto é possível dizer que a paródia necessita de um mínimo de imitação, como também é viável afirmar que a semelhança possa ser bem extensa. Assim, por exemplo, pode-se afirmar que a paródia deve se valer de um mínimo de imitação da obra parodiada, limitando-se a copiar apenas o necessário para viabilizar ao público-alvo o reconhecimento da obra ridicularizada; cópia maior que essa poderia configurar plágio. Por outro lado, também é lógico afirmar que a paródia precisa, muitas vezes, de uma grande imitação da criação da obra originária, pois o recurso cômico utilizado pelo parodista precisa da imitação para ser constatado em toda a extensão da obra.

Tome-se a obra cinematográfica humorística Todo mundo em pânico (2000, com direção de Keenen Ivory Wayans) e suas continuações como exemplo, e constatar-se-ão variações na quantidade de cenas engraçadas que mimetizam outros filmes de terror ou suspense. Pode-se afirmar que a primeira obra a ser ridicularizada em Todo mundo em pânico, e que talvez tenha sido esse o objetivo inicial dos criadores, foi o filme Pânico (de 1996, dirigido por Wes Craven). Assim, na referida paródia, há várias cenas que são imitação cômica de trechos desse filme. Além do filme Pânico, são feitas paródias de algumas outras obras cinematográficas, como Eu sei o que vocês fizeram no verão passado (de 1997, com direção de Jim Gillepsie), A bruxa de Blair (de 1999, dirigido por Daniel Myrick e Eduardo Sánchez), O sexto sentido (de 1999, com direção de M. Night Shyamalan) e Matrix (de 1999, dirigido por Andy Wachowski e Larry Wachowski), embora em quantidades muito menores. Já nas seqüências, como Todo mundo em pânico 2 (de 2001, com direção de Keenen Ivory Wayans), 3 (de 2003, dirigido por David Zucker) e 4 (de 2006, também dirigido por David Zucker), nota-se que a imitação humorística recai, do mesmo modo como ocorre na película original, em um filme que será a linha mestra da paródia, e outras criações primígenas, embora em menor número de cenas. Na sequiência Todo mundo em pânico 2 o filme mais parodiado foi A casa amaldiçoada (de 1999, com direção de Jan de Bont), com referências a cenas também dos filmes O exorcista (de 1973, dirigido por William Friedkin), Horror em Amityville (de 2005, com direção de Andrew Douglas), Poltergeist - o fenômeno (de 1982, dirigido por Tobe Hooper), Rocky, um lutador (de 1976, com direção de John G. Avildsen), A múmia (de 1999, com direção de Stephen Sommers), O homem sem sombra (de 2000, dirigido por Paul Verhoeven), As panteras (de 2000, com direção de McG), Matrix (de 1999, com direção de Andy 
Wachowski e Larry Wachowski), Twister (de 1996, dirigido por Jan de Bont), O tigre e o dragão (de 2000, com direção de Ang Lee), entre outros.

Tanto em Todo mundo em pânico como em suas seqüências, há clara originalidade e uma veia humorística que, inclusive, levaram citadas películas ao sucesso de público. Mas o que fica claro, também, é que nas seqüências em que a utilização paródica consistiu na imitação de um número maior de obras, a originalidade ficou mais evidente e, ao mesmo tempo, reduziu-se a necessidade de aproveitamento de grandes partes das obras parodiadas. Assim, as sequiências de Todo mundo em pânico, que se aproveitaram de menores trechos das obras originárias, não poderiam indicar e demonstrar que o primeiro filme da série valeu-se exageradamente de trechos das criações primígenas?

Se a resposta à pergunta acima for positiva, Todo mundo em pânico, ao menos sob o ponto de vista da legislação autoral brasileira, poderia não cumprir requisito para ser considerada uma paródia propriamente dita. Já, por outro lado, se a resposta for negativa, evidentemente não há que se falar em mera reprodução da obra primígena.

Outro exemplo da complexidade acima apontada reside na forma de criação paródica de sagas, tanto na literatura como no cinema. Utilizando-se novamente a obra cinematográfica como exemplo, uma paródia de $O$ senhor dos anéis (dividido em três partes: O senhor dos anéis - a sociedade do anel, de 2001; O senhor dos anéis - as duas torres, de 2002; O senhor dos anéis - o retorno do rei, de 2003, todas com direção de Peter Jackson), filme que narra, em última análise, a luta do bem contra o mal, em que um grupo de pessoas, cada uma ao seu modo e cumprindo uma função, procura destruir o anel que representa as forças malignas, necessariamente, para cumprir seu papel cômico e criticar a obra em seu todo, precisaria fazer a imitação, se não em sua totalidade, mas ao menos de grande parte da obra, para que o público reconheça toda a intenção do parodista. Fazer o personagem principal morrer logo no início da paródia e alterar drasticamente toda a sequiência da obra poderia, dependendo da maneira como for conduzida pelos autores, reduzir ou até mesmo eliminar a relação com a criação primígena e o efeito humorístico. 
Interessante hipótese de necessidade até mesmo de imitação de toda a obra originária é aventada por Mario Sol Muntañola ${ }^{118}$. Trata-se da paródia de obra plástica. Realmente, nessa hipótese não é viável exigir que a semelhança não recaia sobre toda a obra parodiada. Como poderá existir paródia de um quadro se este não for reproduzido por inteiro?

Como se vê, a análise da extensão da imitação é subjetiva e perigosa. O que para um intérprete pode configurar imitação excessiva, para outro pode parecer enquadrar-se no montante necessário para os fins paródicos.

Conforme o exposto, o requisito legal é de julgamento extremamente difícil e parece ser inútil. Somente haverá segurança para se dizer que não há paródia e, sim, mera reprodução da obra, se essa imitação for muito extensa e desprovida de justificativa plausível; essa situação, porém, configurará plágio, tornando desnecessário esse requisito legal. Ora, é sabido que o plágio é vedado; logo, não haveria necessidade da ressalva contida no artigo 47 da Lei 9.610/98, pois mesmo se esta não existisse, continuaria proibida a mera reprodução da obra originária sem nenhum elemento de originalidade.

B) não provocar descrédito à obra originária

Outro requisito apontado pelo artigo 47 da Lei de Direitos Autorais, porém sem definir critérios para o seu alcance, é a proibição de que a paródia cause descrédito à obra originária.

No âmbito do artigo supracitado, o descrédito deve ser entendido como desonra, menoscabo ou má reputação para a criação primígena. Logo, o requisito legal se refere a aspectos morais e não patrimoniais concernentes à criação parodiada; se assim não fosse, seria mais razoável que a lei se referisse a "prejuízo".

Como uma paródia causaria má reputação à obra originária? Considerando-se que a paródia tem uma idéia de antítese, de negação do texto do autor parodiado, está ínsito a ela um caráter de crítica ou de confronto. É difícil, pois, imaginar que a conversão de uma obra séria em criação humorística, de alguma maneira, não configure um menoscabo para a ${ }^{118}$ MUNTAÑOLA, Mario Sol. El régimen jurídico de la parodia, p. 148. 
criação primígena, já que os efeitos estéticos desejados pelo criador parodiado sucumbirão diante da paródia, que poderá estar presente na memória do público-alvo quando este tiver contato com a obra originária. Logo, por esse aspecto, toda paródia seria apta a prejudicar a reputação da obra parodiada.

O que seria, portanto, esse descrédito que ultrapassaria os limites da natural provocação feita pela paródia, ou seja, considerando-se que toda paródia traz consigo um potencial danoso à criação originária, quando então esse dano passaria a ser considerado como um descrédito conforme a dicção legal?

Não existe resposta clara a essa indagação, pois a constatação do descrédito, por ser algo de significativa subjetividade, deve ser buscada caso a caso. Como regra, é possível dizer que somente haverá um menoscabo à criação parodiada se a acidez e finalidade de crítica do autor da paródia sejam tão grandes que resultem em uma ofensa à criação parodiada.

$\S 2^{\circ}$ Demais requisitos

Além desses dois critérios legais, para que a criação seja reconhecida como paródica deve ter os seguintes requisitos: a) objetivo humorístico, b) diferença com a obra parodiada, c) ausência de prejuízo ao autor parodiado e d) finalidade de crítica à obra parodiada.

A) objetivo humorístico

É forte na doutrina a idéia de que esta criação tem como característica ser um trabalho humorístico. Isso é importante porque, como dito anteriormente ${ }^{119}$, a paródia, na maioria das vezes, apresenta objetivo cômico, mas isso não significa que essa criação intelectual tenha necessariamente que ser humorística. Carlos Rogel Vide, por exemplo, afirma claramente que, pela paródia, uma obra "de séria, passa a ser cômica ou vice-versa $\ldots .120$.

\footnotetext{
${ }^{119}$ Parte 1, Capítulo 1, Seção II, $\S 1^{\circ}$.

${ }^{120}$ VIDE, Carlos Rogel. Derecho de autor, p. 68. “... de seria, pasa a ser cómica o viceversa ...”
} 
Muitos doutrinadores referem-se à paródia como sendo uma criação de humor. Nem sempre é utilizada a palavra "humor", sendo substituída por outras como burlesco, sátira, caricatura, entre outras; todas elas, entretanto, têm nítido objetivo de fazer menção ao caráter cômico.

Entre doutrinadores brasileiros que atrelam a idéia de paródia à produção de efeitos humorísticos podem ser citados Carlos Alberto Bittar ${ }^{121}$, José Carlos Costa Netto ${ }^{122}$, Eduardo Vieira Manso ${ }^{123}$, Newton Paulo Teixeira dos Santos ${ }^{124}$, Jaury Nepomuceno de Oliveira e João Willington $^{125}$, Eliane Abrão ${ }^{126}$ e Elisângela Dias Menezes ${ }^{127}$.

Tendo em vista que a legislação francesa faz referência à paródia, será relevante, a seguir, trazer a lume a lição de alguns de seus doutrinadores, eis que eles identificam o elemento humor como inerente não só à paródia, como também ao pastiche e à caricatura, que também são citados na França.

Henri Desbois, quando trata dessas criações, não é categórico a ponto de afirmar que elas precisam ser humorísticas; porém, como várias vezes refere-se a expressões como "fazer rir" ou a "divertir", conclui-se que segue o entendimento doutrinário padrão ${ }^{128}$.

Alain Le Tarnec ensina que "a paródia é um gênero que supõe uma obra primígena. Ela é sua imitação satírica. O caráter sério da obra primígena é tomado como objeto de uma transposição humorística ou cômica"129.

Na lição de André Françon, "para ser lícita, a paródia deve visar à obtenção de efeitos cômicos" ${ }^{130}$. Pierre-Yves Gautier, por sua vez, em sua obra Propriéte littéraire et

\footnotetext{
${ }^{121}$ BITTAR, Carlos Alberto. Direito de autor, p. 26.

${ }^{122}$ COSTA NETTO, José Carlos. Direito autoral no Brasil, p. 112.

${ }^{123}$ MANSO, Eduardo Vieira. Direito autoral, p. 326-345.

${ }_{125}^{124}$ SANTOS, Newton Paulo Teixeira dos. Paráfrase, paródia e direito autoral, p. 8-11.

125 OLIVEIRA, Jaury Nepomuceno de; WILLINGTON, João. Anotações à lei do direito autoral: Lei no. 9.610/98, p. 96.

${ }^{126}$ ABRÃO, Eliane Yachouh. Direitos de autor e direitos conexos, p. 152.

${ }^{127}$ MENEZES, Elisângela Dias. Curso de direito autoral, p. 107.

${ }^{128}$ DESBOIS, Henri. Le droit d'auteur en France, p. 321-323.

129 TARNEC, Alain Le. Manuel de la propriété littéraire et artistique, p. 89. "La parodie est un genre qui soppose une oeuvre première. Elle est son imitation satirique. Le sujet sérieux de l'oeuvre premiére fait, en quelque sorte, l'objet d'une transposition humoristique ou comique".

${ }^{130}$ FRANÇON, André. Questions de droit d'auteur relatives aux parodies et productions similaires, p. 304:

“(...) pour être licite, la parodie doit viser à obtenir des effets comiques".
} 
artistique, quando analisa o artigo $122-5,4^{\circ}$, da lei francesa, intitula esse tópico da seguinte maneira: "somente fazer rir"131.

Seguindo a mesma linha de raciocínio, além dos juristas citados, outros mais podem ser lembrados, como A Lucas e H. J. Lucas ${ }^{132}$, Claude Colombet ${ }^{133}$, Roland Dumas $^{134}$ e Xavier Linant de Bellefonds ${ }^{135}$, sendo que este, a exemplo de Pierre-Yves Gautier, quando inicia o estudo do citado artigo, utiliza o inequívoco título " $O$ direito ao humor".

Além dos franceses, podem ser citados outros autores estrangeiros que vinculam a paródia à atividade humorística, como Delia Lipszyc ${ }^{136}$, Ricardo Antequera Parilli ${ }^{137}$, Mario Fabiani ${ }^{138}$, Alfredo Arienzo ${ }^{139}$ e Augusto Fragola ${ }^{140}$.

Diante de tão expressivo entendimento doutrinário e, também, reconhecendo-se que o humor é útil ao ser humano, como anteriormente tratado ${ }^{141}$, há que se admitir que o tratamento diferenciado que o direito confere ao humorismo está presente no tocante à paródia que, para o direito de autor, restringe-se à atividade humorística.

Vale destacar, porém, que há doutrinadores, como José de Oliveira Ascensão ${ }^{142}$ e Carlos Rogel Vide ${ }^{143}$, que não se referem ao aspecto cômico, limitando a análise ao caráter antitético da paródia.

Deve-se lembrar, entretanto, que a atividade humorística existente na paródia não tem o condão de necessariamente objetivar o riso. Esta obra pode conter um humor irônico e sutil, pois, dependendo do tema a ser tratado e do tipo de crítica que se faz, não há razão

\footnotetext{
${ }^{131}$ GAUTIER, Pierre-Yves. Propriété littéraire et artistique, p. 349. "Seulement faire rire".

${ }^{132}$ LUCAS, A.; LUCAS, H. J. Traité de la propriété littéraire \& artistique, p. 273.

${ }^{133}$ COLOMBET, Claude. Propriété littéraire et artistique, p. 243.

${ }^{134}$ DUMAS, Roland. La propriété littéraire et artistique, p. 172.

${ }^{135}$ BELLEFONDS, Xavier Linant de. Droits d'auteur et droits voisins, p. 227-229. "Le droit à l'humour".

${ }^{136}$ LIPSZYC, Delia. Derecho de autor y derechos conexos, p. 118.

${ }^{137}$ PARILLI, Ricardo Antequera. La obra como objecto del derecho de autor, p. 56.

138 FABIANI, Mario. La protezione giuridica della parodia com particolare riferimento a recenti orientamenti di giuristi stranieri, p. 462.

${ }^{139}$ ARIENZO, Alfredo. Parodia, p. 448-449.

${ }^{140}$ FRAGOLA, Augusto. Liceità e limiti della parodia alla luce di recenti esperienenze, p. 373.

${ }^{141}$ Parte 1, Capítulo 2, Seções I e II.

${ }^{142}$ ASCENSÃO, José de Oliveira. Direito autoral, p. 65-66.

${ }^{143}$ VIDE, Carlos Rogel. Derecho de autor, p. 68.
} 
para a busca de um efeito exagerado. Isabel Espín Alba, ao analisar essa possibilidade, a exemplifica com a existência de paródias que criticam o trabalho de políticos no enfrentamento de catástrofes e que, diante da gravidade dos fatos tratados, não têm potencial de gerar reações de hilaridade em seus receptores, mas, sim, de ironia $^{144}$.

Questão interessante é a relativa à possibilidade, ou não, da existência de paródia de obra humorística. Essa indagação se justifica já que, como a paródia é uma antítese e comumente é entendida como a imitação burlesca de uma obra séria, restaria impossível uma recriação cômica de uma obra que já tenha caráter humorístico. Não existiria aí a antítese, a relação de semelhança e dessemelhança. Também, embora possível sob o aspecto literário, no concernente ao entendimento que se tem do direito de autor atualmente, não seria considerada paródia a recriação séria de obra cômica (mesmo sendo essa sua verdadeira antítese).

Vale destacar, nesse sentido, a lição de Eduardo Vieira Manso:

E é essa condição burlesca da paródia, cujo propósito é o ridículo, que impede a existência de paródia de obra humorística (no sentido de cômica). Agora, a pretensa paródia dificilmente escapará da figura do plágio e até mesmo da grosseira contrafação, visto que a obra anterior já visava a fazer rir. ${ }^{145}$

Esse entendimento também é defendido por Newton Paulo Teixeira dos Santos ${ }^{146}$.

De fato, reconhece-se que é tarefa extremamente difícil a realização de uma paródia de uma outra obra humorística; porém, em tese, esse intento não é impossível. A criatividade dos autores pode permitir que um grande humorista consiga alterar uma obra cômica dando-lhe outra conotação engraçada e, ainda assim, conseguir um resultado satisfatório.

B) inconfundibilidade com a obra parodiada

\footnotetext{
${ }^{144}$ ALBA, Isabel Espín. La parodia de obras divulgadas, p. 283.

${ }^{145}$ MANSO, Eduardo Vieira. Direito autoral, p. 330.

${ }^{146}$ SANTOS, Newton Paulo Teixeira dos. Paráfrase, paródia e direito autoral, p. 9.
} 
Se a paródia deve necessariamente ser uma imitação parcial da obra originária, essa semelhança não pode ser tão grande a ponto de permitir o risco de confusão entre as criações. Em outras palavras: a paródia deve ser suficientemente distinta da obra imitada para evitar que esta possa ser confundida com aquela.

Como a paródia é uma obra derivada (e, portanto, deve ter originalidade, para ser considerada como criação nova) e uma imitação da criação primígena, surge a dúvida atinente à possibilidade ou não de a obra originária dever ser conhecida do público. Essa indagação se explica porque, independentemente de a paródia conter bastante originalidade e traços distintos do trabalho parodiado, se esta obra não for conhecida, aquele que tiver contato com ela não saberá que se trata de imitação de outra obra.

É possível, por exemplo, que o leitor de uma paródia que não conheça a criação primígena, na eventualidade de posteriormente ter contato com esta, possa acreditar que se trata de uma cópia daquela, situação que comprometerá a reputação do autor parodiado.

De fato, para que o objetivo humorístico da paródia seja alcançado é imprescindível que o público receptor conheça a obra originária, já que é exatamente nesta imitação burlesca que reside a forma de humor utilizada, e a probabilidade de que o público reconheça a obra parodiada será tanto maior quanto mais conhecida for esta criação.

Leciona Isabel Espín Alba que é premissa básica que a obra parodiada seja conhecida, já que a paródia, por ser um discurso antagônico com o da obra originária, tem sua base, seu alicerce, nessa antítese. Sem essa contradição não haveria originalidade ${ }^{147}$.

Se a pessoa que tiver acesso à criação paródica não conhecer a obra originária, não compreenderá todo o conteúdo da paródia, ou seja, não entenderá o humor ali existente. Deve-se ressaltar, porém, que o que caracteriza a paródia é o objetivo do autor, e não se esta intenção foi bem-sucedida. Assim, se um criador, com finalidade humorística, faz a imitação burlesca de uma obra, terá produzido uma paródia, independentemente do fato de as pessoas que tiverem acesso à obra experimentarem, total ou parcialmente, uma sensação de humor.

${ }^{147}$ ALBA, Isabel Espín. La parodia de obras divulgadas, p. 288. 
O autor da paródia, se quiser, pode optar por fazer graça com uma obra desconhecida, pois o que mais a caracteriza é o objetivo humorístico vindo da antítese. Porém, deve-se ressaltar que o mais comum é a satirização de obra conhecida, tornando mais fácil para o público-alvo reconhecer o intento do autor.

C) ausência de prejuízo ao autor parodiado

Tendo em vista que o artigo 47 da Lei 9.610/98 faz referência à proibição de que a paródia cause "descrédito" à criação primígena, o critério ora em comento não se refere à obra imitada, mas, sim, ao seu criador.

Duas são as formas de prejuízo que pode sofrer o autor parodiado: patrimonial e moral.

O prejuízo patrimonial pode consistir na concorrência que a paródia faz em relação à obra parodiada, ou seja, a nova criação não pode servir de substituto da criação imitada.

Se a paródia for muito parecida com a obra originária, além do risco de configurar plágio, poderá se tornar a principal opção de aquisição por parte do público-alvo. Imaginese a hipótese de uma recriação humorística que tenha como objeto a ridicularização de uma anterior obra séria, complexa, de difícil leitura, porém cuja linha principal seja razoavelmente conhecida pelas pessoas em razão de comentários na mídia. É muito provável que essa paródia, principalmente se for uma imitação bem próxima à obra original, receba a predileção dos consumidores por ser de leitura mais agradável e fácil. Assim, a paródia substituiria no mercado a criação parodiada, que seria deixada de lado, perdendo seu potencial de venda o que, conseqüentemente, implicaria redução de rendimentos de seu autor.

Levando-se em consideração também que toda obra é uma criação do espírito, tendo um significativo aspecto personalíssimo para seu autor, não é exagero entender que um criador pode ter sua imagem fortemente atrelada à obra que produziu. Pense-se em $O s$ Lusíadas. Falar nessa criação é automaticamente falar em Camões; referir-se a Camões é automaticamente referir-se a Os Lusíadas, mesmo que se saiba que não foi essa a única produção literária do autor português. 
Assim, em situações muito especiais em que a paródia acaba utilizando um humor que chega a ser agressivo e excessivamente crítico à obra originária, é possível que o autor parodiado, por ter sua personalidade fortemente ligada à obra, possa ser vítima de dano moral.

D) finalidade de crítica à obra parodiada

Uma importante forma de classificação da paródia é a relativa ao seu objetivo. Temos, então, o que se denomina de paródia-alvo e paródia-arma.

A paródia-alvo, também conhecida como paródia-objeto ou target, é aquela por meio da qual seu autor procura fazer graça com a criação parodiada. Assim, o objetivo de crítica se dirige à obra copiada, que se torna o alvo da atividade humorística. Por outro lado, a paródia-arma, também conhecida como paródia-meio ou weapon, se caracteriza pela utilização e transformação da criação primígena não com o objetivo de ridicularizá-la ou de criticá-la, mas, sim, com a intenção de atingir outra obra, pessoa ou fato. Nota-se, nesse caso, que o emprego da palavra "arma" para qualificar esse tipo de criação é adequado, eis que a paródia é exatamente usada para atingir objeto, pessoa ou fato que se encontra fora da relação paródica.

Quanto à paródia-objeto, além da intenção de crítica da criação parodiada, essa crítica pode se estender a outros aspectos inerentes à obra primígena, como, por exemplo, seu tema e a mensagem que procura passar. É necessário, porém, que essa ampliação do círculo de incidência da paródia-alvo não se afaste totalmente do que é ou do que quer dizer a criação parodiada. Logo, a nova criação, mesmo que alcance alguma crítica de algo externo à obra parodiada, tem que manter relação de pertinência com esta, pertinência que não pode se limitar apenas à forma utilizada.

Ora, é claro que a paródia sempre tem alguma relação com a obra parodiada, eis que a imita e, por antítese, acaba por negá-la. Porém, apenas essa imitação parcial não pode ser o suficiente para configurar a crítica que toda paródia deveria conter. $\mathrm{O}$ acima afirmado se explica quando se analisa a idéia de paródia-arma. Por meio desta, seu autor apenas lança mão da imitação cômica, como dito anteriormente, para atacar outra obra, pessoa ou 
fato. A obra copiada é apenas um meio para que o parodista atinja seus fins, que não são de crítica à obra primígena.

Assim, por exemplo, se uma letra de obra lítero-musical é alterada apenas no intuito de, por meio da comicidade resultante dessa técnica de semelhança e dessemelhança, criticar pessoa, coisa ou fato totalmente alheio à obra primígena, não há nenhuma relação de pertinência entre a obra imitada e o objetivo do parodista. Este poderia utilizar inúmeras outras obras para alcançar seu intento. Como a única intenção do parodista foi alterar a letra da obra lítero-musical para atingir seu objetivo (que, repita-se, não é o de criticar a obra parodiada), a utilização desse texto alheio não se justifica, eis que não se mostrava imprescindível para a obtenção do resultado pretendido. Como o autor apenas quis se valer de texto conhecido para efetuar uma crítica, poderia ter usado qualquer outra obra líteromusical e, mesmo assim, alcançaria seu intento. Logo, a escolha, até mesmo aleatória, da obra imitada não teve por trás de si a intenção de crítica mas, na realidade, apenas uma função de aproveitamento de obra alheia para viabilizar ao parodista criar algo engraçado e criticar elemento estranho à obra parodiada.

Um exemplo de paródia-arma citado pela doutrina ${ }^{148}$ se deu nos Estados Unidos da América do Norte no caso Dr. Seuss Enterprises v. Penguin Books USA, Inc. (caso The Cat in the Hat). Na época do julgamento, que teve repercussão internacional, do famoso esportista norte-americano O. J. Simpson, acusado do homicídio da esposa, foi publicado um livro paródico imitando o estilo literário de Dr. Seuss, porém com teor diferente, pois, enquanto este escrevia histórias infantis, aquele narrava o caso citado.

A capa do livro paródico era uma forte imitação da capa de uma das criações de Dr. Seuss, The CAT in the HAT. A obra parodiada apresentava o desenho de um gato com um chapéu listrado e comprido, enquanto a paródia trazia um título parecido, The Cat NOT in the Hat!, e uma caricatura de O. J. Simpson também usando um chapéu listrado e comprido, muito parecido com o da criação primígena. No desenho, O. J. Simpson tinha em suas mãos uma luva ensangüentada, luva essa que, como se sabe, foi usada como argumento de defesa durante o feito.

${ }_{148}$ MUNTAÑLLA, Mario Sol. El régimen jurídico de la parodia, p. 211-212. O referido caso também é citado por William M. Landis e Richard A. Posner, em Fair use, parodia y farsa, p. 201. 
A autora, Dr. Seuss Enterprises, fundamentou seu pedido na infração do copyright e de marca, já que o gato é marca registrada, enquanto a ré, Penguin Books USA Inc., defendeu-se sustentando que o que existia era uma paródia. A decisão favorável à autora concluiu que inexistia uma paródia da obra copiada eis que não se dirigia a esta, mas, sim, o que havia era uma crítica a O. J. Simpson, que nada tinha em relação com a criação de Dr. Seuss.

É a paródia-alvo (ou objeto ou target), na realidade, a verdadeira paródia, sendo a única que se enquadra na idéia de antítese e intertextualidade. É essa criação que efetivamente colide com o texto originário, seguindo em direção oposta ao caminho que o autor parodiado decidiu trilhar. Somente na paródia-alvo está presente o real caráter de negação e crítica da obra primígena, sendo a ela que o art. 47 da Lei 9.610/98 se refere. No sentido de somente a paródia-alvo dever ser considerada lícita é o entendimento de Rafael Sánchez Aristi ${ }^{149}$.

Seção II. Pastiche

Tendo em vista que o pastiche caracteriza-se como sendo a imitação do estilo de outro criador, de seu trabalho como um todo ou de uma concepção estilística reinante em determinado lugar ou época, não se vislumbra que esta modalidade de manifestação humorística tenha potencial de ofensa ao direito de autor do criador de alguma obra específica.

O pastiche não ofende direitos de autor, já que não tem como objeto uma obra específica, sendo apenas uma referência a idéias, a um fazer "à maneira de outro". Assim, não seria mesmo necessária a sua inclusão no artigo 47 da Lei 9.610/98.

Esta modalidade de obra humorística, porém, tem relevância na legislação francesa, pois é expressamente mencionada no parágrafo $4^{\circ}$ do artigo L122-5 do Código de

\footnotetext{
${ }^{149}$ Diz o citado autor: "me parece que es ilícito servirse sin permiso de una obra ajena para parodiar hechos, personajes o situaciones no inherentes a la misma, a salvo que simultáneamente se detecte, siquiera sea de manera parcial, una intención paródica con respecto a la obra utilizada. En mi opinión, por consiguiente, la contemplada por el artículo 39 LPI será la conocida como target parody, em la que el efecto paródico se proyecta sobre la propia obra empleada por el parodista, por contraposición a la llamada weapon parody, en la que la obra empleada por el parodista se convierte en un mero instrumento puesto al servicio de un efecto paródico que se proyecta extra muros de la misma". (La propiedad intelectual sobre las obras musicales, p. 565).
} 
Propriedade Intelectual daquele país, que dispõe que o autor não pode impedir a paródia, o pastiche e a caricatura $^{150}$.

A legislação francesa, ao mencionar o pastiche, além da paródia e da caricatura, exige um esforço interpretativo a fim de identificar a distinção entre essas espécies, principalmente quanto às duas primeiras.

Sobre esse tema é muito citada a lição de Henri Desbois, para quem a paródia se aplica às obras musicais, o pastiche às criações literárias e a caricatura aos trabalhos $\operatorname{artísticos}^{151}$.

André Françon, ao referir-se ao ensinamento de Henri Desbois, porém, ressalta, em nota de rodapé, que não parece ser esse o entendimento da Corte de Cassação, pois esta teria reservado a palavra pastiche para a hipótese em que o objetivo é imitar o "gênero da obra" de um autor, enquanto a paródia e caricatura se refeririam a imitações de "obras específicas" de um autor ${ }^{152}$.

Também versando sobre a divergência acima citada, André Lucas e H. J. Lucas observam que, qualquer que seja a distinção entre paródia, pastiche ou caricatura, em todos esses casos há a aplicação da limitação ao direito de autor. Assim, "não se deveria fazer objeção á utilização da palavra "paródia" em um sentido genérico já que, entre os termos utilizados pelo legislador, é aquele cuja acepção comum parece ser mais ampla"153.

Parece ser esse o caminho trilhado pela doutrina da França, pois dedica grande parte de seus estudos à paródia, deixando de lado o pastiche e a caricatura, ou seja, a análise feita no concernente à paródia seria o suficiente para a compreensão da extensão e limites da lei francesa.

\section{Seção III. Caricatura}

\footnotetext{
150 "Article L122-5

Lorsque l'ouvre a été divulguée, l'auteur ne peut interdire:

$4^{\circ}$ La parodie, le pastiche et la caricature, compte tenu des lois du genre."

${ }^{151}$ DESBOIS, Henri. Le droit d'auteur em France, p. 321.

${ }^{152}$ FRANÇON, André. Questions de droit d'auteur relatives aux parodies et productions similaires, p. 302.

${ }^{153}$ LUCAS, A.; LUCAS, H. J. Traité de la propriété littéraire \& artistique, p. 273.
} 
A caricatura, desde que seja original, é obra protegida pelo direito de autor. Embora não citada expressamente na Lei 9.610/98, por tratar-se de desenho, pintura ou escultura, está abarcada pelo inciso VIII, do artigo $7^{0^{154}}$ da referida Lei, que tem a seguinte redação:

\author{
"Art. $7^{o}$ São obras intelectuais protegidas as criações do \\ espírito, expressas por qualquer meio ou fixadas em qualquer \\ suporte, tangível ou intangível, conhecido ou que se invente no \\ futuro, tais como: \\ VIII - as obras de desenho, pintura, gravura, escultura, \\ litografia e arte cinética".
}

Vale destacar, porém, o entendimento de Regina Sahm que defende estar a caricatura contida num sentido amplo de paródia. Em suas palavras, "trata-se da paródia realizada por meio da arte plástica em que há exageros de traços para representar

\footnotetext{
${ }^{154} \mathrm{O}$ artigo $7^{\circ}$ é extenso e tem o seguinte teor:

“Art. $7^{\circ}$ São obras intelectuais protegidas as criações do espírito, expressas por qualquer meio ou fixadas em qualquer suporte, tangível ou intengível, conhecido ou que se invente no futuro, tais como:

I - os textos de obras literárias, artísticas ou científicas;

II - as conferências, alocuções, sermões e outras obras da mesma natureza;

III - as obras dramáticas e dramático-musicais;

IV - as obras coreográficas e pantomimas, cuja execução cênica se fixa por escrito ou por outra qualquer forma;

$V$ - as composições musicais, tenham ou não letra;

VI - as obras audiovisuais; sonorizadas ou não, inclusive as cinematográficas;

VII - as obras fotográficas e as produzidas por qualquer processo análogo ao da fotografia;

VIII - as obras de desenho, pintura, gravura, escultura, litografia e arte cinética;

IX - as ilustrações, cartas geográficas e outras obras da mesma natureza;

$X$ - os projetos, esboços e obras plásticas concernentes à geografia, engenharia, topografia, arquitetura, paisagismo, cenografia e ciência;

$X I$ - as adaptações, traduções e outras transformações de obras originais, apresentadas como criação intelectual nova;

XII - os programas de computador;

XIII - as coletâneas ou compilações, antologias, enciclopédias, dicionários, bases de dados e outras obras, que, por sua seleção, organização ou disposição de seu conteúdo, constituam uma criação intelectual.

$\$ 1^{\circ}$ Os programas de computador são objeto de legislação específica, observadas as disposições desta Lei que lhes sejam aplicáveis.

$\$ 2^{\circ}$ A proteção concedida no inciso XIII não abarca os dados ou materiais em si mesmos e se entende sem prejuízo de quaisquer direitos autorais que subsistam a respeito dos dados ou materiais contidos nas obras.

$\S 3^{\circ}$ No domínio das ciências, a proteção recairá sobre a forma literária ou artística, não abrangendo o seu conteúdo científico ou técnico, sem prejuízo dos direitos que protegem os demais campos da propriedade imaterial".
} 
geralmente pessoas que exerçam cargos públicos, políticos, pessoas notórias, ídolos”"155. Essa linha de raciocínio segue o caminho trilhado por Eduardo Vieira Manso ${ }^{156}$.

Seguindo esse ponto de vista, a citada Professora sustenta que caricatura está protegida na legislação autoral pelo artigo 47 da Lei 9.610/98. Porém, com a devida vênia, não é esse o melhor entendimento, já que, embora a caricatura e a paródia façam parte do gênero "obras de humor", não são elas iguais. Enquanto esta apresenta raio de ação maior, podendo ser encontrada na literatura, na música, no cinema etc., aquela está circunscrita preponderantemente às artes visuais.

O alvo da imitação burlesca também é claramente distinto: obras preexistentes, no caso da paródia, e seres humanos, em se tratando de caricatura. Outro aspecto a ser destacado é a característica da significativa deformação da imagem existente na caricatura; já na paródia, essa alteração não precisa ser tão intensa, bastando que a nova obra contenha alguma originalidade e se refira suficientemente à criação primígena.

Independentemente do argumento utilizado para justificar a proteção autoral da caricatura, parece restar imune a críticas a idéia de que ela é uma criação do espírito e, portanto, está dentro da esfera do direito de autor.

Por outro lado, esse tipo de criação artística não é obra derivada, já que não se baseia em outra obra, mas, sim, na reprodução da imagem de outra pessoa, no mesmo sentido do conceito de fotografia.

Aproximar a caricatura da idéia de obra fotográfica não ajuda a resolver o conflito de direitos, pois aquela tem menor caráter tecnológico do que esta. Enquanto a fotografia tem seu caráter criativo e original ligado necessariamente a uma reprodução mecânica (máquina), a caricatura pode ser mais artesanal, como, por exemplo, com a simples utilização de papel e lápis, praticamente em nada dependendo de tecnologia mais avançada para vir a lume.

\footnotetext{
${ }^{155}$ SAHM, Regina. Direito à imagem no direito civil contemporâneo: de acordo com o novo Código Civil, Lei n. 10.406, de 10-1-2002, p. 210.

${ }^{156}$ MANSO, Eduardo Vieira. Direito autoral, p. 334.
} 
É claro que o desenho pode até ser feito por intermédio do computador e seus modernos meios de expressão gráfica; porém, esse é apenas um dos vários instrumentos que o caricaturista tem em mãos, como o lápis, o nanquim, o carvão etc. Por mais semelhante que a fotografia de uma pessoa seja com o seu desenho ou pintura, estes ainda serão reproduções menos exatas da imagem do que ocorre com a aquela. Assim, a caricatura não deve receber o mesmo tratamento jurídico dado à fotografia.

Tendo em vista que a caricatura expõe pessoas ao ridículo, já que se caracteriza pela reprodução deformada da imagem de alguém, questão pertinente que se coloca é saber se o exagero caricatural, por ser humorístico, é ofensivo. Claudio Luiz Bueno de Godoy, referindo-se ao humor na imprensa, hipótese na qual as caricaturas podem estar incluídas, entende que a comicidade é ínsita a essa atividade; logo, “... apenas em condições extremas e explícitas será possível enxergar ofensa à honra ou à imagem, especialmente, derivada de

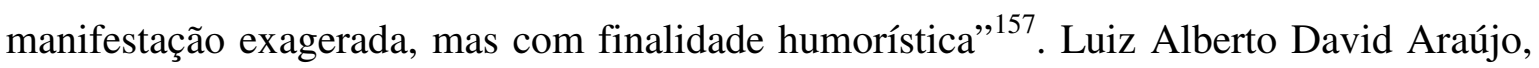
por sua vez, reconhece que o exagero característico da caricatura seria proibido pelo direito, mas ressalva que os costumes o admitem, e conclui que

...na verdade, é permitida a alteração da imagem, desde que não
injuriosa. (...) A deformação da imagem pela caricatura não atinge o
direito à proteção imagem-retrato. Pode, no entanto, ameaçar o direito
à imagem-atributo ou mesmo o direito à honra da personalidade
retratada. $^{158}$

Apesar de o entendimento acima indicado seja merecedor de todo o respeito, não parece ser o melhor. A reprodução da imagem distorcida intencionalmente pelo autor tem um inerente potencial de dano à imagem do caricaturado, que pode até mesmo ser presumido. Certamente, as pessoas retratadas nesse tipo de obra de engenho podem não gostar de ter sua imagem utilizada, sentindo-se envergonhadas com isso, principalmente levando-se em consideração que os autores costumam realçar características desfavoráveis dos retratados, tornando a imagem risível. Imagine-se o exemplo de pessoa que tenha determinada característica física que a constranja em público e, por esse motivo, procure ocultá-la o máximo possível. Ressalte-se que não é raro que essas situações causem até

${ }_{158}^{158}$ GODOY, Claudio Luiz Bueno. A liberdade de imprensa e os direitos da personalidade, p. 103.

158 ARAUJO, Luiz Alberto David. A proteção constitucional da própria imagem, p. 91-92. 
problemas psicológicos. Como essa pessoa se sentiria diante de uma caricatura que explore justamente aquilo que lhe causa vergonha e desconforto psicológico?

A conclusão a que se deve chegar no concernente à pergunta acima é a que indica que recebe primazia o direito à imagem da pessoa caricaturada. Justifica-se tal posicionamento. Não haverá grande prejuízo ao artista, pois ele terá vedada apenas a possibilidade de criação de uma obra específica: a caricatura de determinada pessoa. Por outro lado, é imprescindível a proteção do direito à imagem do retratado porque este direito é inerente ao ser humano e deve ser exercido constantemente, não sendo adequada nenhuma violação, mesmo que passageira e a título de constituir-se em mera "brincadeira" caracterizada pelo não tão inofensivo animus jocandi .

Trata-se de hipótese em que estão em confronto, de um lado, o direito do caricaturista de produzir uma criação do espírito e, por meio dela, fazer humor, e, de outro lado, o direito do caricaturado de não ver sua imagem indevidamente divulgada, principalmente considerando-se que essa imagem vem distorcida e apta a servir de motivo de riso para outrem.

Tendo em vista o confronto acima exposto, deve-se analisar se há necessidade ou não de autorização da pessoa caricaturada para que a obra possa ser divulgada.

Pontes de Miranda é categórico ao defender que a autorização não é exigível porque

a caricatura é a imagem do que se reflete, da fisionomia ou do todo humano, na psique do caricaturista; é imagem de imagem; pode bem acontecer que apanhe mais do que a fotografia e obtenha exprimir mais do que o retrato a óleo ou a lápis. Mas, por isso mesmo que se tira da imagem interior, não pode opor-se à sua feitura o caricaturado. $^{159}$

Entretanto, pode-se afirmar que é forte o entendimento no sentido de que, conforme leciona Enéas Costa Garcia, "em princípio, o uso da imagem é considerado ilícito quando

\footnotetext{
${ }^{159}$ PONTES DE MIRANDA, Francisco Cavalcanti. Tratado de direito privado, Tomo VII, p. 62-63.
} 
levado a termo sem a autorização do titular. Todavia este princípio não se aplica no caso em que a caricatura é utilizada como meio para o exercício da liberdade de informar"160. Na mesma direção segue Regina Sahm ${ }^{161}$.

Não existe argumento plausível para justificar que o simples intento de fazer humor, mesmo que respaldado pelo direito de autor, que é um direito sui generis, com aspectos de direito de propriedade e direito de personalidade, possa suplantar o direito à imagem do caricaturado que, sem dúvida, é um direito da personalidade.

A caricatura tem apenas efeito cômico, vindo da comparação entre a imagem real do caricaturado, conhecida de quem vê a obra, e a imagem deformada. Há graça nessa relação de semelhança e exagero na maneira como a pessoa foi retratada. Não há mensagem a ser transmitida; existe apenas um humor feito com base na imagem de pessoa conhecida.

Nesse caso, não há razão para a utilização da imagem alheia. Nem mesmo o argumento de que políticos e pessoas famosas poderiam ser caricaturados livremente, já que, por iniciativa própria, se colocam em evidência, deve merecer guarida. $\mathrm{O}$ direito à imagem, mesmo que de pessoas muito conhecidas, não deve sofrer atenuação quando não há interesse público que o justifique. Nesse sentido, com o devido respeito, não se concorda com a posição adotada por Fernanda Orsi Baltrunas Doretto, segundo a qual “... o caricaturista geralmente volta seus esforços para retratar a pessoa notória, famosa. Seria absurdo exigir o consentimento expresso do personagem retratado, em se tratando de celebridades, já que ninguém gosta de se expor ao ridículo" ${ }^{\text {"162 }}$. É exatamente o fato de que ninguém quer se expor ao ridículo, reconhecido pela autora acima citada, que justifica a necessidade de autorização.

O fato de se tratar de criação artística não explica e nem autoriza a desnecessidade de permissão do caricaturado. Se esse entendimento estivesse correto, por que, então, não seria livre a reprodução deformada da imagem de alguém quando feita, não com objetivo de fazer rir, mas, sim, com a intenção de causar medo? Ora, o objetivo do autor de causar

\footnotetext{
${ }^{160}$ GARCIA, Enéas Costa. Responsabilidade civil dos meios de comunicação, p. 212.

${ }^{161}$ SAHM, Regina. Direito à imagem no direito civil contemporâneo: de acordo com o novo Código Civil, Lei n. 10.406, de 10-1-2002, p. 210.

${ }^{162}$ DORETTO, Fernanda Orsi Baltrunas. Direito à imagem, p. 119.
} 
horror não estaria lançado em uma criação artística, igualmente protegível? A resposta afirmativa se impõe, mas, certamente, o retratado, nesse caso, teria muito mais possibilidade de sucesso em uma demanda judicial em face do artista. Assim, mesmo sendo uma criação intelectual, esse tipo de obra sem objetivo cômico dificilmente seria admitido, já que estaria ferindo o direito à imagem do caricaturado.

O que se vê, portanto, é que a obra de engenho, o fruto do intelecto do autor, está limitada pelos direitos da personalidade do retratado. Admitir que a caricatura, por ser criação do espírito e ter objetivo humorístico, seria livre, implicaria negar às formas de retratar o ser humano desprovidas de intenção cômica a proteção autoral. Para se evitar esse tratamento diferenciado a alguns tipos de criação intelectual poder-se-ia sustentar, então, que todas as maneiras de reprodução do aspecto físico do ser humano seriam livres; porém, é sabido que essa reprodução depende de autorização, admitindo-se apenas exceções que tenham respaldo no interesse público.

Outro exemplo pode ser apresentado. Jornais e revistas populares às vezes colocam a caricatura de pessoa famosa com objetivo de simplesmente ilustrar matéria que a esta diga respeito. Nesse caso, a utilização da caricatura deve ser livre? Não, porque a identificação da pessoa citada pode ser feita por meio de fotografia que, por não ser uma deformação da imagem, é menos danosa ao retratado.

Porém, no caso da análise da colisão entre o direito à imagem dos caricaturados e o direito à liberdade de informação e expressão dos caricaturistas (que muitas vezes estão ligados a órgãos de imprensa), a questão é mais complexa, exigindo a verificação de vários aspectos.

Para a ponderação desses direitos, mister se faz distinguir caricatura e charge, o que será feito a seguir.

Seção IV. Charge

Como dito anteriormente, a caricatura é o retrato humorístico de uma pessoa, feito por desenho, pintura ou escultura, caracterizado pela deformação intencional da imagem do retratado, enquanto a charge é o desenho que tem como objetivo, utilizando-se da via 
humorística, criticar fatos determinados. O que é livre é a charge, emanação da liberdade de expressão e do direito de crítica. Nesse tipo de criação existe o objetivo do chargista de transmitir uma idéia, geralmente de crítica política ou de costumes. Há, portanto, uma mensagem a ser apresentada ao público e, em razão disso, não é raro que esse tipo de desenho seja freqüente em jornais e revistas.

Para que o chargista alcance seu intento, ele poderá valer-se da reprodução da imagem de uma pessoa específica, por exemplo um político ou esportista conhecido. Por outro lado, poderá simplesmente criar sua obra aludindo ao fato que se quer criticar, sem recorrer à inserção da imagem de pessoas específicas; para tanto, seu desenho pode não conter a imagem de pessoas ou, se contiver, utilizar-se de pessoas fictícias, meras criações do espírito do autor. Exemplo dessa última hipótese é o desenho de pessoas trajando terno e chapéu contendo um cifrão para indicar banqueiros, sem necessitar fazer referência a nenhum banqueiro real.

A charge passa a ter relevância para o direito quando retrata pessoas específicas, pois nesse caso há o confronto entre o direito de liberdade de expressão do chargista e o direito à imagem do retratado. Quando a criação do chargista não se refere a nenhuma pessoa específica, não há que se questionar sobre sua legalidade, eis que não existe qualquer colisão de direitos.

Por também tratar da imagem de pessoas, pode se entender que existe uma certa confusão entre os conceitos de "caricatura" e "charge", muitas vezes tratadas como palavras sinônimas, quando não o são. O ponto principal da charge é a crítica, que é feita por intermédio do humor, enquanto, no caso da caricatura, o objetivo é apenas humorístico. Naquela, o humor é apenas um meio para alcançar um fim; já, nesta, o humor é a finalidade.

Uma circunstância que pode explicar a dificuldade da distinção entre essas modalidades de obras intelectuais é que pode ocorrer que uma charge contenha uma caricatura. Isso ocorre para o fim de aumentar o efeito engraçado; porém, o objetivo continua sendo a crítica. Essa hipótese também pode ser explicada pelo fato de a charge ser um desenho que pode ser feito com rapidez, já que os fatos a serem criticados surgem a cada momento. Não é difícil imaginar, em uma redação de jornal, uma charge ser feita 
poucos momentos antes do fechamento da edição em razão de se referir a fato ocorrido há poucos minutos. Assim, o realce de algumas características das personalidades retratadas, como, por exemplo, a barba do Presidente Luis Inácio Lula da Silva, ou o topete do exPresidente Itamar Franco, além do efeito engraçado, ajudam aos desenhistas, em poucos traços, identificar a quem as charges se referem.

É importante ressalvar que não se está aqui tentando reduzir o valor estético das charges. Não. Isso seria incorreto e iria contra forte premissa do direito de autor, que é a impossibilidade de se discutir o mérito das obras. O que se procura mostrar é que eventual efeito caricatural em uma charge não se limita ao propósito de fazer rir, mas tem outras explicações, como a necessidade de facilitar a identificação dos personagens ou o objetivo de realçar visualmente o que está a criticar.

Como exemplo da característica de crítica da charge, é importante mencionar decisão da justiça paulista em ação em que o autor, um juiz federal, alegou dano à sua honra em razão de um desenho publicado pela ré com título Bloco dos sujos, na qual magistrados eram mostrados em festejos carnavalescos. Por ser juiz, entendia que a criação humorística, por si só, ofendia sua honra. O referido desenho fazia crítica ao Supremo Tribunal Federal, já que este concedeu benefício salarial a juízes federais. O pedido foi julgado improcedente em primeiro grau de jurisdição.

No julgamento da Apelação pelo Tribunal de Justiça de São Paulo, esclareceu a Desembargadora Relatora que

“a charge expressou opinião crítica quanto à decisão da
Suprema Corte, fato de repercussão nacional e de interesse
público, valendo-se da representação humorística, sem
desbordar dos limites do estilo burlesco, próprio das charges,
para escancarar o repúdio em relação àquela iniciativa
considerada extravagante - daí a referência ao luxo - e
insultante à população em geral, sofredora com a falta de 
reajustes salariais, tudo como é absolutamente comum nestas situações. (...)”. 163

Também é charge o desenho humorístico que se refere a fato real, mesmo que desprovido de cunho político. Nesse sentido, deve-se lembrar de um caso em que a autora, caseira do condomínio em que trabalhava, viu-se envolvida em acidente automobilístico com seu veículo dentro das dependências do local. O fato foi objeto de charge publicada no boletim interno do condomínio, o que, segundo a autora, tornou-a objeto de pilhérias, causando-lhe danos morais.

A pretensão acima não teve sucesso, entendendo o Tribunal de Justiça de São Paulo que a conduta da ré foi correta, pois retratou evento real e de conhecimento dos moradores do condomínio, não havendo ofensa à autora.

Interessante nesse Acórdão é que ficou reconhecido, no voto do Relator, que a charge reproduziu "com exagero proposital, as características dos personagens, inclusive atribuindo-lhe linguagem própria", mas que não foram suficientemente fortes para caracterizar dano moral. Nas palavras do Magistrado, "pode ter havido um ligeiro constrangimento, ou um aborrecimento, mas que têm relação mais direta com o próprio fato real do que com a sua reprodução humorística"164.

Para a aferição da legalidade do uso da imagem de alguém com objetivo chárgico é útil trazer para esse tipo de obra intelectual a distinção de alvo e arma existente na paródia. Da mesma forma que a imitação cômica de uma obra pode ser uma paródia-alvo (se a finalidade do parodista é a crítica à obra originária) ou paródia-arma (que se dá quando a intenção de seu autor é fazer graça criticando elementos estranhos à criação primígena), a charge, quando utiliza a imagem de alguma pessoa real, também pode ser assim classificada.

163 “INDENIZAÇÃO - Danos morais - Charge - Opinião crítica expressada por meio de representação burlesca de decisão do Supremo Tribunal Federal e do Presidente da República - Admissibilidade - Ofensa à honra não caracterizada - Indenização indevida - Recurso improvido." (TJSP, Apelação Cível n. 188.1374/2-00, 3 Câmara “A” de Direito Privado, j. 20-04-2007, v.u., Rela. Desa. Carina Margarido).

164 "Indenização por Danos Morais - Publicação de charge humorística revelando fato real e de conhecimento público anterior - Inexistência de repercussão ou de intenção de ofender - Aborrecimentos, incômodos, desconforto ou enfado decorrentes de alguma circunstância, que o homem médio tem de suportar em razão do convívio em sociedade não configura dano moral indenizável - Recurso improvido." (TJSP, Apelação Cível n. 514.516-4/2-00, $7^{\text {a }}$ Câmara de Direito Privado, j. 15-08-2007, v.u., Rel. Des. Luiz Antonio Costa) 
Há, por exemplo, charge-alvo na reprodução da imagem de governantes quando estes, de alguma forma, têm relação com o fato que se quer criticar. O mesmo ocorre com esportistas ou artistas. Logo, não há ofensa ao direito à imagem quando um prefeito é retratado comicamente em situação afeta à sua atividade no Poder Executivo, como na escolha de seus secretários. Isso também ocorre quando um esportista é objeto de charge relacionada ao seu âmbito de atuação, como na hipótese do desenho humorístico reproduzindo imagem de um jogador de futebol que esteja claramente acima do peso ideal retratando-o lutando sumô.

Por outro lado, haverá charge-arma se o personagem retratado não tem nenhuma relação com o fato objeto da charge. Imagine-se o caso em que um artista famoso tenha sua imagem reproduzida em charge que tenha por finalidade criticar decisão governamental na área econômica. Se o referido artista não tiver relação com a decisão econômica, não haverá justificativa para inserção de sua imagem na charge.

O que se observa é que juristas que tratam da caricatura, quando afirmam que essa expressão artística não depende de permissão dos retratados quando estes são políticos ou famosos, ou quando a imagem é lançada pela imprensa, na realidade, estão referindo-se à charge. É por isso que não há necessidade de autorização.

Entretanto, quando se pensa na caricatura, que é desprovida de mensagem crítica, não há razão para a dispensa da autorização do retratado. Não há interesse público a ser protegido.

Assim, quando o chargista opta pela utilização da imagem de pessoa específica, que seja conhecida e tenha relação com aquilo que pretende ser mostrado pelo autor, mesmo que a pessoa seja retratada de forma risível, a charge não deve receber obstáculos. Nesse caso justifica-se o uso da imagem de alguém, pois na charge este direito é afastado para prevalecer o interesse público da liberdade de expressão e de informação.

Vale lembrar, porém, que, apesar de seu cunho crítico e de comentário a fatos e a pessoas dele participantes, podem ocorrer exageros, havendo mais uma intenção de provocação do que de crítica. Um exemplo disso ocorreu em charges publicadas pelo 
jornal dinamarquês Jyllands-Posten, em 30 de setembro 2005, em virtude de um concurso. Várias relacionavam o islamismo com o terrorismo. Uma delas, por exemplo, retratava Maomé com um turbante em forma de bomba. A publicação dessas charges levou a discussões sobre políticas de imigração e integração, bem como a intervenção de embaixadores de onze países islâmicos frente ao governo dinamarquês, exigindo desculpas. As charges foram consideradas a maior afronta já sofrida pelo islamismo, gerando protestos que chegaram a provocar a morte de várias pessoas. Alguns países retiraram seus embaixadores da Dinamarca e houve boicote a produtos dinamarqueses.

Com relação às citadas charges, Sami Naïr faz interessante comparação para que os ocidentais possam melhor entender a ofensa sentida pelo islã. Todos ficariam indignados caso, no momento em que Sharon bombardeava Henín, houvesse sido publicada uma charge de Moisés pilotando um avião israelita. Conclui que, do mesmo modo que Moisés nada tem a ver com Sharon, Maomé também não é Bin Laden ${ }^{165}$.

Apesar de se entender que a charge é livre, não ofendendo a imagem do retratado (desde que ele tenha alguma pertinência com o que se quer criticar), pode haver ofensa à honra, o que faz com que a charge adentre na seara da ilicitude.

Seção V. Cartum

Tendo em vista que cartuns abordam fatos do cotidiano, sem identificação exata de pessoas, não se vislumbra que possam ofender a imagem de alguém, não havendo, assim, qualquer tipo de conflito. Caso venham a ofender a honra, não poderão ser permitidos.

Seção VI. Quadrinhos

Os desenhos em quadrinhos, quando de humor, e as tiras cômicas, desde que utilizados de forma usual, não terão o condão de ferir direitos, não gerando qualquer tipo de conflito.

O que pode ocorrer, porém, é que outra forma de expressão humorística seja feita utilizando os quadrinhos como instrumento. Pode-se citar, como exemplo, tira cômica ${ }^{165}$ NAÏR, Sami. Libertad y sagrado: el caso de las viñetas, p. 43. 
criada para criticar um político devido a um ato por ele praticado em sua vida pública. Nesse caso, haverá charge e, apesar de estar no formato de quadrinhos, o tratamento jurídico que deve ser dado ao desenho é o da charge.

\section{Seção VII. Anedotas}

Não há óbice legal para a admissão das anedotas como objeto do direito de autor, desde que dotadas de criatividade e originalidade, tendo sido exteriorizadas. $\mathrm{O}$ fato de muitas vezes serem apresentadas oralmente também não lhes retira a protegibilidade.

O que se deve ter em conta não é a facilidade ou dificuldade da identificação do autor, mas, sim, se essas criações, mesmo que rápidas e curtas, são obras de engenho dignas de se posicionarem dentro da esfera do direito de autor. Dessa análise resulta claro que as piadas, dotadas de criatividade e originalidade e devidamente exteriorizadas, são criações do espírito merecedoras de proteção jurídica da mesma maneira como ocorre com obras de maior extensão.

É válido lembrar que o direito de autor não está a perquirir o mérito da obra; esta será objeto de direito mesmo que seja curta, singela, de gosto duvidoso ou, até mesmo, grosseira e chula. O livro de muitas páginas é protegido da mesma forma que a simples piada também o é.

Desse modo, mesmo que na prática seja difícil a prova da autoria das anedotas, principalmente quando expressadas de forma oral, ou se mostre inviável a propositura de ações para coibir utilizações indevidas, que podem se espalhar rapidamente por toda uma região, ou até mesmo por todo o Brasil, essas situações não têm o condão de afastar a incidência da legislação autoral para a defesa dessas criações.

A prova da autoria das piadas pode ser feita de variadas maneiras, como a demonstração de que a anedota há tempos faz parte do repertório do humorista em seu show, os registros de concursos, as gravações de espetáculos, a divulgação da autoria em livros, jornais e revistas, entre outras. Como se sabe, o âmbito probatório de uma criação artística, literária ou científica é amplo, não se limitando a registros públicos. Assim, se o 
autor desincumbir-se satisfatoriamente da tarefa de demonstrar que é o criador da obra, nada deverá impedi-lo de exercer seus direitos advindos da atividade intelectual.

É possível aventar-se que a transmissão oral das anedotas pode ser de extrema conveniência para os autores que, dessa forma, conseguem constatar o tipo de criação humorística que melhor alcança o intento de fazer rir, o grupo de pessoas mais receptivo a esse tipo de linguagem e os temas mais apreciados. Nesse contexto, realmente é viável a conclusão de que a proteção autoral nem seja o maior interesse dos criadores; porém, a falta de conveniência de pugnar pela defesa dos direitos por parte dos autores, não implica a inexistência dos mesmos.

A proteção das piadas, por exemplo, pode ser de extrema importância para seus autores quando elas são utilizadas por outros humoristas. Nesse caso, principalmente nas hipóteses de atuação nas mesmas espécies de atividades exercidas pelo criador (apresentação de shows ao vivo, atuação em programas de rádio ou televisão, elaboração de livros de anedotas etc.) a proteção autoral é relevante para o criador, tanto para evitar que o produto de seu talento e criatividade seja usado por profissional que atua no mesmo ramo, como para, no mínimo, divulgar o nome do verdadeiro criador.

Reconhecida a inclusão das piadas na esfera autoral, resta indagar se elas, apesar do humor que lhes é inerente, podem ter um conteúdo ofensivo. A resposta é positiva. Se as anedotas, embora criativas, ultrapassarem o limite do animus jocandi, são passíveis de ofender terceiros.

Note-se que as piadas muitas vezes podem ter um conteúdo preconceituoso, referindo-se, pejorativamente, a grupos de pessoas, pelos mais diversos motivos, como a nacionalidade, religião e opção sexual. Nesse sentido, Derek Brewer observa que "tradicionalmente, as piadas tendem a endossar o preconceito popular, através da universalmente praticada piada étnica, ou o antifeminismo quase tão universal, em várias formas, ou ainda o escárnio dos deficientes físicos"166.

\footnotetext{
${ }^{166}$ BREWER, Derek. Livros de piada em prosa predominantes na Inglaterra entre os séculos XVI e XVIII, p.
} 134. 
Tais anedotas podem ter, assim, um grande potencial danoso, tal qual ocorre também com as charges ${ }^{167}$. A diferença na repercussão que piadas e charges apresentam está no fato de que aquelas, muitas vezes, são de autoria desconhecida, enquanto que essas têm seus criadores devidamente indicados e contêm um elemento visual que pode aumentar a reação indignada do público.

É freqüente no Brasil piadas sobre portugueses, tendo-os como menos inteligentes que os brasileiros. É evidente que tal conotação não condiz com a realidade, existindo razões para explicar esse tipo de anedota. Foram os portugueses que colonizaram o Brasil e aqui dominaram por muito tempo, restando aos brasileiros apenas a possibilidade de se sentirem mais valorizados considerando os lusitanos como menos capazes.

De qualquer forma, a pessoa objeto da anedota freqüentemente acaba sendo colocada em uma situação inferior em relação ao humorista ou seu público, pois "rir de alguém" supõe que o agente é superior à pessoa ridicularizada. Note-se que nem sempre a pessoa retratada na piada é colocada em situação de inferioridade, como ocorre em piadas sobre crianças espertas que dão respostas inteligentes e inesperadas aos seus interlocutores (como pais ou professores); nesse caso, se valoriza mais a figura da criança do que a dos interlocutores que, inesperadamente, se submeteram a essa demonstração de inteligência. Apesar disso, as anedotas que de alguma forma ridicularizam seus personagens surgem constantemente.

Apesar de as anedotas poderem ser ofensivas e representarem uma colocação de pessoas como se fossem seres inferiores, dos quais se é permitido rir, é necessário ter cautela na análise da responsabilidade jurídica dos criadores de piadas.

Somente podem ser passíveis de causar danos piadas dirigidas a uma pessoa específica ou a um grupo muito restrito. Por outro lado, não se vislumbra que piadas mais genéricas, que se refiram a um grande grupo de pessoas, possam ser lesivas. Observe-se o caso de piadas de advogados; embora essas anedotas freqüentemente sejam pejorativas em relação a esses profissionais, não há que se dar guarida ao argumento de que elas envergonham todos os causídicos. Nesse sentido, o Tribunal de Justiça de São Paulo

\footnotetext{
${ }^{167}$ Como exemplos de charges ofensivas podem ser lembradas as já citadas charges de Maomé, publicadas no jornal dinamarquês Jyllands-Posten, em 30 de setembro 2005.
} 
decidiu que não sofreu dano moral uma professora de fonoaudiologia que se insurgiu contra uma piada que, embora não se referisse diretamente a ela, ao seu modo de ver, menosprezava os profissionais dessa classe ${ }^{168}$.

Vale ressalvar que o mesmo Tribunal, desta vez analisando o alcance de piada genérica sobre a polícia civil, em ação proposta por associação dos delegados de polícia, decidiu de forma diferente, entendendo ter ocorrido ofensa à honra, pois a anedota, mesmo que não referida a pessoa determinada, mas, sim, a uma classe de profissionais, ultrapassou os limites da jocosidade, ofendendo a honra e respeitabilidade de todos os seus membros ${ }^{169}$.

Seção VIII. Imitação cômica

A utilização de imitação da voz ou imagem humanas é comum no teatro, no cinema e na televisão ${ }^{170}$, mostrando-se um recurso humorístico freqüente. Tendo em vista a inerente potencialidade de dano ao direito à imagem ou à voz, mister se faz analisar as consequiências jurídicas advindas de tal prática.

A imitação pode se dar por meio visual ou sonoro. A visual costuma ser expressa pela utilização de atores caracterizados, que, ao se valerem de recursos como máscaras, perucas, maquiagem, próteses, vestimentas, entre outros, se tornam parecidos com os imitados. A participação de sósias também busca esse intento, em razão da natural semelhança física. Deve, ainda, ser feita referência ao aproveitamento de bonecos para o

\footnotetext{
168 "Dano moral - Inocorrência - Caso em que não houve ofensa pessoal dirigida à apelante, mas a veiculação de uma simples piada envolvendo os fonoaudiólogos - Mero incômodo que não caracteriza dor moral - Recurso improvido." (TJSP, Apelação Cível 287.856-4/5-00, 9ª Câmara de Direito Privado, Rel. Des. José Luiz Gavião de Almeida, v.u., j. 28.06.2008).

169 "Indenização - Dano moral perpetrado contra associação de classe e respectivos filiados, por aquela representados - Escrito de caráter manifestamente ofensivo, não vingando a escusa de que produzido simplesmente com animus jocandi - Vulneração de direitos à honra e à imagem, também protegidos constitucionalmente e que não podem ser relegados, sob fundamento de tutelado o exercício da livre manifestação do pensamento - Embargos infringentes rejeitados." (TJSP, Embargos Infringentes 233.3574/1-02, $10^{a}$ Câmara de Direito Privado, Rel. Des. Quaglia Barbosa, maioria de votos, j. 05-11-2002).

${ }^{170}$ Adriano De Cupis, ao referir-se às formas de se retratar uma pessoa, menciona a máscara cênica, que é a representação de alguém em um espetáculo, ressaltando que "deve notar-se que a representação teatral ou cinematográfica pode resultar particularmente expressiva, podendo fixar-se na memória do espectador, bem mais do que, por exemplo, o retrato reproduzido em um jornal ilustrado, o qual é geralmente olhado mais ou menos de forma rápida, por alto. Além do mais, a voz do artista reforça o efeito da reprodução, completando o retrato e tornando-o mais eficaz - o que avoluma, de fato, a ilusão de ter diante de si a pessoa representada" (Os direitos da personalidade, p. 144).
} 
mesmo fim. Já no caso da imitação sonora, as possibilidades são mais restritas, vislumbrando-se a utilização por pessoas que, em razão da capacidade de se aproximarem muito da expressão vocal dos imitados e, também, por realçarem vícios de linguagem e maneirismos destes, conseguem remeter o ouvinte ao registro sonoro da voz do imitado.

A perquirição das consequiências jurídicas do trabalho desses humoristas, assim como já dito no concernente às paródias, caricaturas e charges, passa pela observação da finalidade do imitador ao se referir à imagem ou voz dos retratados. Em outras palavras, cabe indagar se o que o humorista busca com a semelhança visual ou sonora é apenas o resultado humorístico ou fazer uma crítica.

Para a análise acima sugerida, é necessário, novamente, valer-se da idéia de "alvo" e "arma" já tratada em momentos anteriores ${ }^{171}$.

A imitação visual considerada "alvo" se dá quando o imitador incorpora a imagem de outrem e, com ela, apresenta situação cômica relacionada a fato pertinente ao imitado. Seria o caso, portanto, de um quadro televisivo em que o humorista assume a aparência de políticos, esportistas ou artistas para fazer graça com situações por estes vividas. Recentemente, na campanha eleitoral norte-americana, que recebeu atenção de todo o mundo face à proeminência e papel exercido pelos Estados Unidos da América do Norte como potência mundial e que, direta ou indiretamente, influencia o destino de todo o planeta, ganhou destaque a atuação da humorista Tina Fey que, com grande competência, imitou Sarah Pallin, candidata a vice-presidente pelo Partido Republicano. Tratava-se de atuação que, além do objetivo humorístico, visava a destacar diversos aspectos da candidata, como um possível despreparo para a função e a pouca preocupação com o meio ambiente, entre outros.

Será entendida como "arma" a imitação visual na qual o humorista não busca brincar com fato relacionado ao imitado, procurando, na realidade, ridicularizar situação com a qual este não tem nenhum vínculo. Imagine-se, como exemplo, a imitação de políticos, esportistas ou artistas incluída em esquete que verse sobre situação que não guarde relação com as atividades exercidas pelos retratados. Em tais casos, o objetivo do humorista seria tão somente valer-se da imagem de alguém para alcançar efeito cômico,

\footnotetext{
${ }^{171}$ Parte 2, Capítulo 2, Seções I e IV.
} 
que seria obtido da mesma forma caso não houvesse imitação, ou seja, caso o humorista se apresentasse como verdadeiramente é. A utilização da imagem alheia, nessa hipótese, tem unicamente objetivo humorístico, despido de finalidade de crítica.

No caso da imitação visual como "alvo", ela não dependerá de autorização do imitado, já que o direito de crítica supera o direito à imagem. O mesmo não ocorre na imitação visual como "arma", já que o objetivo unicamente humorístico, desacompanhado do intento de crítica ao retratado, não suplanta o direito à imagem.

O mesmo raciocínio acima indicado vale para a hipótese de imitação sonora, sendo importante a análise do intento do humorista. Para isso, os conceitos de "alvo" e "arma" continuam úteis.

Será "alvo" a imitação sonora que relacione a voz propalada com algo que efetivamente tenha pertinência com o ramo de atividade exercida ou atos específicos praticados pelo imitado. Um exemplo é a imitação da voz de Edson Arantes do Nascimento, o conhecidíssimo Pelé. Por ocasião da feitura de seu milésimo gol, esse grande futebolista, naquele momento que entrou para a história do futebol, nas entrevistas concedidas, lembrou das "criancinhas do Brasil"172. Essa dedicatória foi inúmeras vezes objeto de imitação cômica. Porém, não há que se sustentar ter ocorrido ofensa ao direito à voz, já que o trabalho dos humoristas versou sobre algo efetivamente relacionado com o citado atleta.

Por outro lado, será "arma" a imitação sonora que coloque o satirizado em situação que em nada se relacione com as atividades por ele exercidas. Utilizando-se Pelé novamente como exemplo, seria "arma" a imitação de sua voz para simplesmente contar uma anedota. Nesse caso, a imitação da voz do esportista não se justificaria, eis que fora de um contexto a ele relacionado. O humorista poderia ter contado a piada utilizando sua própria voz, sem precisar recorrer à alheia, e a mensagem engraçada seria transmitida da mesma forma.

\footnotetext{
172 O milésimo gol de Pelé ocorreu em 19-11-1969, no Maracanã, em uma partida entre Santos e Vasco, pelo Torneio Roberto Gomes Pedrosa.
} 
Não merece guarida eventual alegação de que a imitação sonora nunca dependeria de autorização, já que o humorista, na realidade, estaria usando sua própria voz, e não a alheia. Conforme informado, a voz é única, individualizando as pessoas igualmente como ocorre com a impressão digital ${ }^{173}$. Mesmo que a voz não seja idêntica em cada indivíduo, resta claro que a imitação remete o ouvinte à lembrança da pessoa satirizada; é nisso que, em grande parte, reside o efeito humorístico. O público ri porque, mesmo sabendo que a voz propalada é do humorista, por ser ela tão parecida, praticamente igual à do imitado, reconhece-o. Logo, novamente tomando-se a voz de Pelé como exemplo, a imitação remete o ouvinte à lembrança desse esportista.

O mesmo se diga com relação à imitação visual. Note-se o caso dos sósias. Estes, quando atuam em quadros cômicos, o fazem para, em razão de grande semelhança fisionômica, remeterem o público à imagem do satirizado. Assim, o efeito cômico advém da imagem do imitado ser reconhecida no sósia; este, apesar de se valer de seu próprio corpo, o que o deixa em destaque não é a sua individualidade, mas, sim, aquilo que o associa ao imitado.

É importante destacar que, caso haja ofensa à honra, a imitação, mesmo que seja alvo, não poderá ser considerada lícita.

Seção IX. Esquetes, entrevistas humorísticas e câmeras escondidas

Tanto emissoras de televisão como de rádio, reconhecidas por serem meios de comunicação de grande relevância, dependendo do viés mercadológico em que atuam, em especial para a chamada "comunicação de massas", costumam apresentar programas humorísticos de alta audiência. Em algumas dessas atrações, lamentavelmente, são cometidos abusos que causam danos aos direitos da personalidade de terceiros, no concernente ao direito à imagem, à voz, à honra e à privacidade. Levados os fatos ao Poder Judiciário, registram-se decisões condenatórias que reconhecem que a atividade humorística, nos casos concretos, foram lesivas.

Um exemplo de humor ofensivo é o caso em que um famoso apresentador de televisão teve sua imagem-retrato apresentada em um boneco e sua voz imitada em um 
quadro humorístico de um programa televisivo de entretenimento, no qual esse boneco dizia frases de conteúdo sexual e erótico. O apresentador imitado, que não tinha sua imagem-atributo ligada a esse tipo de conteúdo, propôs ação requerendo a condenação das rés, a emissora e a apresentadora do programa, à indenização por danos patrimoniais e compensação por danos morais. A defesa das rés baseou-se na circunstância de que a imagem mostrada foi de um boneco, e não do próprio autor da demanda, bem como se tratava de atividade humorística incapaz de prejudicá-lo. O Tribunal de Justiça de São Paulo manteve a sentença de primeiro grau de jurisdição, entendendo que a conduta das rés foi ofensiva ao autor e condenou-as ao pagamento de quantias relativas a danos materiais e danos morais ${ }^{174}$.

Outro caso de total exagero na atividade humorística em programas de televisão é citado por Silvio de Salvo Venosa. Trata-se de fato em que baratas vivas foram jogadas sobre transeunte, com o objetivo de se captar as imagens da reação da vítima. Proposta a ação, em sua defesa, a ré alegou que agiu sem intenção de prejudicar a autora, pois a atividade era humorística, além do fato de se tratar de obtenção de imagem em via pública e de o rosto da autora não ter sido divulgado, pois, na edição, fôra coberto com um mosaico. O Tribunal de Justiça de São Paulo decidiu pela procedência do pedido formulado na inicial, rechaçando os argumentos da ré e condenando-a ao pagamento de quinhentos salários mínimos à autora ${ }^{175}$.

\footnotetext{
174 "Dano moral - Ofensas perpetradas a personalidade de renome nacional, em programa televisivo de entretenimento e em quadro eminentemente humorístico - Não incidência da Lei de Imprensa, por expressa exclusão (Art. $\left.1^{\circ}, \S 2^{\circ}\right)$ - Transmissão que se enquadra no conceito de "espetáculos e diversões públicas" Necessidade, de qualquer forma, de respeito à intimidade, à honra e à boa fama de terceiros - Uso de boneco com feições e voz semelhantes a de jornalista famoso, atribuindo-lhe frases de cunho sexual e erótico - Evidência do uso indevido da imagem e do dano moral causado - Quantum bem dimensionado, que não deve obedecer aos limites previstos em referido diploma legal, tanto por sua não incidência na espécie, quanto por sua não recepção pela Constituição Federal de 1988 - Sentença de procedência mantida Recurso das rés desprovidos".

(TJSP - Apelação Cível n. 469.168-4/1-00, $1^{\text {a }}$ Câmara de Direito Privado, Rel. Des. De Santi Ribeiro, j. 0603-2007, v.u.)

175 "Dano moral - Responsabilidade civil - Utilização indevida de imagem - Programa humorístico de televisão - Baratas vivas despejadas sobre a autora, que transitava em via pública - Ocorrência - Terror que repercutiu na atividade psíquica da vítima, que não se confunde com mera brincadeira - Uso não autorizado da imagem - Não desvirtuamento por se tratar de filmagens em local público, nem pelo uso de 'mosaicos' - Punição que deve ser exemplar, para que o ofensor não reincida na conduta - Caráter reparatório, punitivo e pedagógico da indenização por dano moral - Majoração da indenização Admissibilidade - Indenização devida fixada em montante equivalente a 500 salários mínimos - Recurso da autora provido" (TJSP - Apelação Cível 433.412-4/8-00, 22.8.2006, 3ª Câmara de Direito Privado - Rel. Caetano Lagrasta).” In: VENOSA, Silvio de Salvo. Direito civil: parte geral, p. 175.
} 
Também vale destacar o ocorrido com o ator Wagner Moura que, na ocasião em que saía de um evento, quando foi abordado por um repórter de televisão, ao parar para conceder o que imaginava ser uma entrevista, foi surpreendido com a aplicação de, sem consulta e, muito menos, permissão, um tipo de gel em seus cabelos. Indignado com o abuso praticado contra ele, o ator escreveu o artigo intitulado Meleca no ator que foi publicado no jornal $O$ globo, em 29-05-2008. Em razão de sua relevância e impacto, parte do artigo é a seguir transcrito:

(...) Meu Deus, será que alguém realmente acha que jogar meleca nos outros é engraçado? Qual será o próximo passo? Tacar (...) nas pessoas? Atingir os incautos com pedaços de pau para o deleite sorridente do telespectador? Compartilho minha indignação porque sei que ela diz respeito a muitos; pessoas públicas ou anônimas, que não compactuam com esse circo de horrores que faz, por exemplo, com que uma emissora de TV passe o dia INTEIRO mostrando imagens da menina Isabella. Estamos nos bestializando, nos idiotizando. O que vai na cabeça de um sujeito que tem como profissão jogar meleca nos outros? É a espetacularização da babaquice. Amigos, a mediocridade é amiga da barbárie! E a coisa tá feia.

Digo isso com a consciência de quem nunca jogou o jogo bobo da celebridade. Não sou celebridade de nada, sou ator. Entendo que apareço na TV das pessoas e gosto quando alguém vem dizer que curte meu trabalho, assim como deve gostar o jornalista, o médico ou o carpinteiro que ouve um elogio. Gosto de ser conhecido pelo que faço, mas não suporto a falta de educação. $O$ preço da fama? Não engulo essa. Tive pai e mãe. Tinham pai esses paparazzi que mataram a princesa Diana? É jornalismo isso? Aliás, dá para ter respeito por um sujeito que fica escondido atrás de uma árvore para fotografar uma criança no parquinho? Dois deles perseguiram uma amiga atriz, grávida de oito meses, por dois quarteirões. Ela passou mal, e os caras continuaram fotografando. Perseguir uma grávida? Ah, más tá reclamando de quê? Não é famoso? Então agüenta! O que é isso gente? (...). ${ }^{176}$

${ }^{176}$ MOURA, Wagner. Meleca no ator. 
Wagner Moura mencionou os chamados paparazzi, que são fotógrafos especializados em flagrar a imagem de pessoas famosas em sua intimidade ou em situações constrangedoras, e responsabilizou-os pelo ocorrido com a Princesa Diana ${ }^{177}$ que, após sair de um luxuoso hotel com um possível namorado, foi perseguida nas ruas de Paris por tais profissionais, envolveu-se em grave acidente e faleceu. De fato, tem havido um abuso dos meios de comunicação na divulgação de fatos relacionados à vida de pessoas famosas. Mesmo admitindo-se que tais pessoas tenham seu direito à privacidade reduzido, é certo que os paparazzi cometem abuso de direito em sua busca por informações.

Merece destaque julgado do Tribunal de Justiça do Rio de Janeiro em caso que versou sobre a atividade humorística com intromissão na privacidade alheia, inclusive com repercussões negativas para um menor. Uma atriz conhecida nacionalmente foi várias vezes abordada por humoristas de um programa televisivo para participar de determinado quadro. Em decorrência de sua recusa, a artista passou a ser perseguida pelos humoristas que, inclusive, em determinada ocasião, além de gritos e do uso de auto-falantes, utilizaram um guindaste para tentar alcançar o apartamento no qual ela reside com um filho impúbere. Além dos transtornos causados pela confusão que se formou diante do edifício, o mesmo foi exibido na televisão, fato este que divulgou onde é a residência da atriz. O Tribunal entendeu que houve exposição desnecessária da autora e de sua família, condenando a emissora ao pagamento de compensação de danos morais ${ }^{178}$.

Um expediente diversas vezes utilizado em programas humorísticos televisivos é a participação de convidados ou de entrevistados em lugares públicos, como praias, praças e ruas. Essas entrevistas costumam ser carregadas de ironia e frases de duplo sentido,

\footnotetext{
177 É comum que os paparazzi sigam pessoas famosas à busca, não de fotos dessas pessoas em momentos normais do dia-a-dia, mas, sim, para flagrá-las em situações cômicas ou constrangedoras, ou até mesmo revelando ocorrências que deveriam permanecer em segredo. Por exemplo, artistas ou esportistas são fotografados com namoradas sem que seja dado a eles o direito de recusa de terem tanto a imagem como esses fatos privados fotografados e divulgados.

178 "Direito Constitucional. Liberdade de expressão versus direito a intimidade. Atriz que manifesta sua vontade de não aparecer, nem participar de brincadeira, ao seu ver vexatória, em programa humorístico. Exposição da sua vida íntima, afetando seu cotidiano, causando incômodo também a seu filho. Aplicação do princípio da observância do interesse da criança. Interesse mediato da criança em ter resguardada a sua honra e a liberdade de imagem e movimentação de sua mãe.

"O Ministério Público se debruça sobre a proteção dos intocáveis direitos legítimos dessa criança que tem de ser resguardados de quaisquer objetivos de uma expressão de humor abusivo, desrespeitoso e até grotesco, a agredir sua personalidade em formação" (parecer ministerial de fls. 244/245, do Agravo de Instrumento n. 19245/05 da Procuradora de Justiça Dra. Elaine Costa da Silva).

Desprovimento dos recursos".

(TJRJ - Apelação Cível n. 2007.001.15019 e n. 007.001.15027 (julgamento em conjunto) - 6 Câmara Cível - Rel. Des. Nagib Slaibi, j. 13-06-2007, v.u.)
} 
freqüentemente versando sobre algo diverso do que realmente está sendo dito. Um exemplo se encontra em perguntas que, aparentemente inofensivas, estão relacionadas a sexo ou a outros temas que possam ser delicados para o participante do programa.

Uma forma de entrevista ofensiva ocorre nas situações em que o repórter ou entrevistador faz perguntas totalmente absurdas para os entrevistados, como, por exemplo, se estes estão informados sobre fictício projeto de lei para revogar a lei da gravidade. $\mathrm{O}$ que está por trás desse tipo de pergunta nada mais é do que o objetivo de explorar a falta de informação das pessoas, já que, se estas forem muito ingênuas ou mal-informadas, em vez de demonstrarem ciência de que as indagações são um disparate ou, caso nada saibam sobre o tema, admitirem essa condição, podem tentar responder aos questionamentos, tornando-se motivo de ridicularização. $\mathrm{Na}$ realidade, nessas perguntas cômicas não são dadas aos entrevistados alternativas satisfatórias pois, por estes não terem conhecimentos sobre o assunto, ou reconhecem a própria ignorância ou, ao tentar escondê-la, sem perceber acabam revelando-a e se submetem a uma situação humilhante e risível.

Os humoristas que se valem desse tipo de estratégia podem sustentar que têm o objetivo de crítica, denunciando o baixo nível de informação de parcela da população e o falho sistema educacional do Brasil. Essa finalidade, que é correta e útil para o país, entretanto, não pode justificar a colocação de pessoas menos favorecidas intelectualmente em situações ridículas, eis que, inocentes e sem condições de notar a malícia contida nos questionamentos, acreditam estar respondendo a perguntas sérias.

Outra modalidade de quadros cômicos na televisão são as câmeras ocultas ou câmeras escondidas, mais popularmente conhecidas como pegadinhas. Sem saber que estão sendo filmadas, as vítimas são submetidas a situações inusitadas, embaraçosas e que podem aparentar a existência de um perigo iminente. Muitos são os exemplos, como a câmera oculta em que a vítima, acreditando estar em uma séria entrevista de emprego, não sabe o que fazer ao ver gavetas inexplicavelmente se abrindo em mesas e armários na sala, ou a situação em que um ator se passa por doente com dificuldades para caminhar, pede dinheiro a transeuntes e, ao obter a ajuda de alguém, deixa as muletas e sai andando normalmente com o dinheiro recebido. 
Embora Santos Cifuentes não se refira especificamente às câmeras escondidas, parece ser elas o alvo de seu comentário ao afirmar que a exposição da imagem humana pode se dar com o uso de subterfúgios, lembrando, em uma tradução livre, que os retratados "às vezes, inclusive, foram enganados e convencidos de que outra era a qualidade do programa, o qual está em mãos tão técnicas e experientes que conseguem a nota cômica aproveitando reações, gestos, ou até mesmo a inocência e a surpresa" ${ }^{\prime 17}$.

A questão que se coloca é indagar se a participação voluntária nesses programas elimina a responsabilidade das emissoras de televisão e dos idealizadores dos quadros relativa a eventuais ofensas e constrangimentos causados aos participantes.

A resposta a esse questionamento passa pelo tema da necessidade de autorização do participante para a utilização de sua imagem ou voz. Não há dúvida de que é imprescindível a autorização para esse uso. O que merece destaque, porem, não é a existência do consentimento, mas, sim, o teor e a qualidade dessa permissão.

Nesse sentido é válido lembrar a idéia de consentimento informado, tão comum nos temas de biodireito. Não basta para a validade de autorização, naquele ramo do direito, que o contratante ou participante de uma atividade relacionada à biologia (como, por exemplo, reprodução humana assistida, transplantes e outros procedimentos médicos) simplesmente consinta com o procedimento que será adotado; é necessário mais, ou seja, essa autorização, para produzir efeitos jurídicos, deverá vir acompanhada de ampla e anterior informação sobre o que será feito, especificando-se os riscos e os benefícios a que a pessoa se submeterá.

Um exemplo do acima citado vem da reprodução humana assistida. Esta, que pode apresentar-se pela inseminação artificial (IA) ou pela fecundação in vitro (FIV), envolve diversos questionamentos e repercussões jurídicas e éticas. Um aspecto de grande relevância é a possibilidade da chamada gravidez múltipla ou multiparidade.

\footnotetext{
${ }^{179}$ CIFUENTES, Santos. Derechos personalísimos, p. 533. “... a veces, inclusive, llegaron con engaño y convencidos de que otra era la calidad del programa, el cual está en manos técnicas y avezadas que consiguen la nota cómica aprovechando reacciones, gestos, o hasta la misma inocencia y sorpresa."
} 
Nos casos de fecundação in vitro, na qual a concepção ocorre em laboratório, portanto, fora do corpo da mulher, vários zigotos são implantados no corpo da gestante, a fim de possibilitar maior possibilidade de resultado positivo na gestação, fazendo crescer as chances de que ao menos um deles desenvolva-se com sucesso e resulte no nascimento do novo ser humano. Conforme determinação do Conselho Federal de Medicina, devem ser implantados, no máximo, quatro zigotos.

Se essa implantação, por um lado, aumenta a possibilidade de o procedimento médico ser coroado de êxito, por outro, faz crescer a probabilidade de que, em vez de um único zigoto desenvolver-se, mais de um, até mesmo todos os quatro desenvolvam-se satisfatoriamente, resultando em uma gestação de gêmeos, trigêmeos ou quadrigêmeos, configurando-se a gravidez múltipla.

Ora, a gestação e o nascimento de um filho obviamente é o desejo do casal que se submete à fecundação in vitro; porém, é de se questionar se o mesmo casal deseja e tem condições adequadas para o nascimento de vários filhos num mesmo momento. É, pois, de fundamental importância que os futuros genitores sejam devidamente esclarecidos sobre a possibilidade da ocorrência de multiparidade para que decidam se irão prosseguir no intento de submeter-se aos procedimentos de reprodução humana assistida ou não. Como se vê, não basta que o casal meramente autorize o início dos trabalhos, é necessário que esse consentimento venha acompanhado de ampla e prévia informação, o chamado consentimento informado.

Trazendo a idéia de consentimento informado para o tema em análise, é possível concluir que não basta a simples autorização de divulgação da imagem ou voz dos participantes do programa de televisão ou de rádio para que as emissoras estejam isentas de responsabilidade por ofensas ou constrangimentos contra eles praticados. Torna-se imperiosa a prévia informação de que o programa tem cunho humorístico e que pode colocar o participante em situações constrangedoras e vexatórias, portanto, risíveis aos telespectadores ou ouvintes. Assim, a mera autorização genérica para a utilização da imagem ou da voz não presume é demonstração suficiente da concordância de seus subscritores com o teor da utilização a ser dada pelas emissoras. Vale perguntar: a simples autorização, sem maiores detalhamentos, da divulgação da imagem e da voz de um entrevistado em sua resposta a uma pergunta que este não sabia que era capciosa e poderia 
levá-lo à ridicularização, é suficiente para eximir a emissora de sua responsabilidade? A resposta negativa se impõe.

Essa idéia de consentimento informado faz com que, na hipótese de uma não detalhada autorização para a utilização da imagem ou da voz em um programa de humor, o ônus da prova de que houve o consentimento informado caberá às emissoras de televisão ou rádio, presumindo-se que o participante não conhecia a real extensão e finalidade do aproveitamento de sua imagem ou voz.

Essa presunção, porém, é relativa e pode cair por terra se as circunstâncias da participação da pessoa demonstrarem total ciência da forma de atuação dos humoristas. Nesse sentido, mister se faz realçar uma interessante ação julgada pelo Tribunal de Justiça de São Paulo, em que a autora, pessoa conhecida no meio artístico, participou de programa de rádio e alegou em juízo que foi humilhada pela forma como foram realizadas as perguntas e os comentários dos humoristas. Levando em consideração a circunstância de que a autora conhecia o tipo de humor realizado no programa, o Tribunal não acolheu a pretensão indicada na inicial $^{180}$.

180 "DIREITO À IMAGEM - Indenização - Dano moral - Pessoa conhecida do meio artístico que alega ter sido humilhada e sofrido perseguição, após sua participação em programa de rádio, o qual também é transmitido pela televisão, sentindo-se atingida em sua honra - Suposta vítima que concordou em participar como entrevistada do programa, sabendo a que tipo de perguntas e piadas estaria submetida Circunstância em que não houve a intenção deliberada de ofender, já que a atração, de cunho humorístico, é realizada dentro dos parâmetros a que se propõe - Verba indevida." (TJSP, Apelação Cível 516.278-4/0-00, $3^{\text {a }}$ Câmara de Direito Privado, Rel. Des. Beretta da Silveira, v.u., j. 11.03.2008, In RT 873/193). 


\title{
CAPÍTULO 3. O FAIR USE E A PARÓDIA
}

\author{
Seção I. O fair use
}

Originário do direito anglo-saxão, o copyright norte-americano versa sobre o direito de autor, porém com características distintas da forma como este é compreendido no direito continental europeu no qual a legislação brasileira tem raízes.

A citada diferença entre direito de autor e copyright também se manifesta no tocante às limitações desses direitos. Como já anteriormente visto, tais limitações no direito nacional devem ser interpretadas restritivamente; já no caso do copyright, o surgimento da idéia do fair use permite uma interpretação mais ampla.

O fair use, que pode ser traduzido como "uso justo" ou "uso leal", nem sempre constou na legislação americana, tendo sido criado pela via jurisprudencial. Considera-se que o primeiro caso analisado sob a luz do fair use nos Estados Unidos se deu em 1841, no caso Folsom v. Marsh ${ }^{181}$. Esse feito versava sobre o fato de ser justo ou não o uso feito pelos réus da obra dos autores da ação. Tratava-se de cópia de várias páginas dos escritos de George Washington, cujos direitos pertenciam aos autores da ação. A Suprema Corte rejeitou o argumento do fair use, condenando os réus, por entender que é possível a cópia de trechos de outra obra para fins de crítica, mas, por outro lado, se o objetivo é o de concorrer com a criação copiada, esse uso não é justo.

Ao julgar o caso, o Juiz Story, da Suprema Corte, expôs alguns critérios que deveriam ser analisados nas decisões envolvendo fair use: natureza e objeto das seleções feitas, quantidade e valor dos materiais usados e em que grau o uso pode prejudicar a obra protegida, como prejuízo nas vendas ou diminuição de lucro.

Após essa decisão, e por muitos anos, o fair use foi tratado apenas pela jurisprudência norte-americana. Em 1976, tal doutrina foi incorporada ao direito escrito,

\footnotetext{
${ }^{181}$ Conforme noticiam, por exemplo, Eduardo Lycurgo Leite (A doutrina do "fair use" delineada no direito autoral norte-americano: uma ferramenta para o ponto de equilíbrio entre a rigidez autoral e o interesse público relevante, p. 117-120), Marshall Leaffer (Understanding copyright law, p. 319), Judith B. Prowda (Parody and fair use in copyright law: setting a fairer standard in Campbell v. Acuff-Rose Music, Inc., p. 6061) e Carlos Eduardo Neves de Carvalho (A doutrina do fair use nos EUA, p. 50).
} 
passando a integrar a Seção 107 do Copyright Act que, em uma tradução livre, tem o seguinte teor:

“Não obstante as previsões das seções 106 e 106 A, o uso justo de uma obra protegida pelo direito de autor, incluindo o uso por reprodução em cópias ou discos sonoros ou mediante qualquer outro meio especificado nessa seção, para propósitos tais como a crítica, comentários, reporte de notícias, ensino (incluindo cópias múltiplas para o uso em aula), instrução ou investigação, não é uma infração ao direito de autor. Para determinar se o uso feito de uma obra em um caso particular é um uso justo, os fatores a serem considerados devem incluir:

(1) O propósito ou caráter do uso, incluindo se o mesmo é de natureza comercial ou se tem um propósito educacional sem fins lucrativos;

(2) A natureza da obra objeto de proteção;

(3) A quantidade e substancialidade da porção usada em relação à obra como um todo;

(4) $O$ efeito de tal uso sobre o mercado potencial ou o valor da obra.

O fato de que a obra seja inédita não impedirá em si mesmo considerar um uso justo, se tal consideração está feita sobre os fatores acima mencionados". ${ }^{182}$

Todos os critérios apresentados pela Seção 107 devem ser considerados na busca pelo fair use, isto é, mesmo que se entenda que um uso dificilmente será justo analisando-

\footnotetext{
${ }^{182}$ Copyright Act: " $\$ 107$ Limitations on exclusive rights: Fair use

Notwithstanding the provisions of sections 106 and 106A, the fair use of a copyrighted work, including such use by reproduction in copies or phonorecords or by any other means specified by that section, for purposes such as criticism, comment, news reporting, teaching (including multiple copies for classroom use), scholarship, or research, is not an infringement of copyright. In determining whether the use made of a work in any particular case is a fair use the factors to be considered shall include - (1) the purpose and character of the use, including, whether such use is of a commercial nature or is for nonprofit educational purposes; (2) the nature of the copyrighted work; (3) the amount and substantiality of the portion used in relation to the copyrighted work as a whole; and (4) the effect of the use upon the potential market for or value of the copyrighted work.

The fact that a work is unpublished shall not itself bar a finding of fair use if such finding is made upon consideration of all the above factors".
} 
se um dos critérios, ainda assim será necessário verificar o uso sob a luz dos demais ${ }^{183}$. É interessante notar que os quatro fatores são em muito semelhantes aos critérios explicitados pelo Juiz Story ao julgar o primeiro caso envolvendo fair use (Folsom v. Marsh). Além da análise dos quatro critérios, os Tribunais, se entenderem necessário, podem considerar outros fatores existentes no caso concreto, como a má-fé de quem fez uso da obra protegida, o costume da indústria ou até a mesmo a prática ${ }^{184}$.

O primeiro fator que deve ser analisado (objetivo e caráter do uso) requer investigação para se saber se o uso teve intuito comercial ou se a finalidade era educacional ou não lucrativa.

O objetivo do primeiro critério é apenas perquirir se há fim lucrativo, ou seja, qual é intuito do criador da obra derivada, e não se a obra nova afetou o mercado da criação primígena, já que essa discussão se insere no quarto fator. Da leitura do primeiro critério, pode-se concluir que a lei norte-americana procura evitar que a nova obra seja uma simples imitação da criação originária, devendo-se considerar, também, se a obra tem natureza comercial ou não. Caso o uso tenha ocorrido para obtenção de lucro, presume-se que não houve uso justo.

Ínsita ao primeiro critério está a idéia de que, para ser considerado justo, o uso deve ser "transformativo". A noção de "uso transformativo" surgiu no cenário do fair use em um artigo escrito por Pierre Leval, Juiz da Segunda Circunscrição. Para que seja atingido o objetivo do copyright (promoção do progresso da ciência e das artes, previsto pela Constituição dos Estados Unidos da América do Norte - Artigo I, Seção 8, alínea 8) ${ }^{185}$, o fair use deve somente ser considerado em casos em que o réu usa a obra original de modo ou com objetivos diferentes. Como lecionam Diane Leenheer Zimmerman ${ }^{186}$ e Judith B. Prowda ${ }^{187}$, a primeira análise a ser feita para incluir-se uma obra no âmbito do fair use é verificar se ela apresenta um forte uso transformativo, ou seja, se difere suficientemente da

\footnotetext{
${ }^{183}$ LEAFFER, Marshall. Understanding copyright law, p 319 e 322.

${ }^{184}$ LEAFFER, Marshall. Understanding copyright law, p 322.

${ }^{185}$ U.S. Constitution - Article I - Section 8, cl. 8:

"The Congress shall have Power

(8) To promote the Progress of Science and useful Arts, by securing for limited Times to Authors and Inventors the exclusive Right to their respective Writings and Discoveries".

186 ZIMMERMAN, Diane Leenheer. The more things change, the less they seem "transformed": some reflections on fair use, p.254-257.

${ }^{187}$ PROWDA, Judith B. Parody and fair use in copyright law: setting a fairer standard in Campbell v. AcuffRose Music, Inc., p. 79-80.
} 
criação primígena a ponto de não dar margem à possibilidade de confundirem-se as duas obras. Assim, os Tribunais, adotando o entendimento do Juiz Pierre Leval, passaram a perquirir a existência de uso transformativo para reconhecer a ocorrência de fair use.

Deve-se ressaltar que, após a introdução da idéia de uso transformativo para a análise do primeiro fator, não mais se admitiu a mera cópia como uso justo, nem mesmo se a cópia tivesse utilidade social. Pode-se citar como exemplo o caso American Geophysical Union v. Texaco, Inc., narrado por Diane Leenheer Zimmerman ${ }^{188}$. Trata-se de caso em que técnicos da Texaco fizeram cópias para seus arquivos pessoais de jornais científicos subscritos pela companhia. Ao julgar o feito, o Juiz Leval negou que um uso com utilidade social pudesse satisfazer o primeiro fator, sendo necessário algum tipo de transformação da obra primígena.

Conforme noticia Diane Leenheer Zimmerman ${ }^{189}$, muitos Tribunais deixam de reconhecer o fair use por falta de uso transformativo da obra derivada, embora, ao serem analisadas, tais obras mostrem grande transformação se comparadas com os originais. A doutrinadora norte-americana cita como exemplos os casos Castle Rock Entertainment, Inc. v. Carol Publishing Group, Inc. ${ }^{190}$ e Los Angles News Service v. KCAL-TV ${ }^{191}$.

O segundo fator do fair use trata da natureza da obra primígena. Algumas obras que contêm informações de maior interesse público terão maior chance de serem respaldadas pelo fair use. Na lição de José de Oliveira Ascensão, "é de supor que nas obras mais fácticas o âmbito da utilização fair seja maior que nas obras mais imaginativas”"192. Assim, é mais provável que um uso seja justo se a obra primígena for histórica ou científica do que se for criação que tenha por finalidade o entretenimento. Também é assim se a obra

\footnotetext{
${ }^{188}$ ZIMMERMAN, Diane Leenheer. The more things change, the less they seem "transformed": some reflections on fair use, p. 255.

189 ZIMMERMAN, Diane Leenheer. The more things change, the less they seem "transformed": some reflections on fair use, p. 258-259.

${ }^{190}$ Neste caso, o réu havia criado livro de trívia baseado nos episódios de uma famosa comédia de situações norte-americana (Seinfeld). Embora o uso transformativo fosse claro, já que o livro não reproduzia o enredo da série, apenas usando informações de modo fragmentário, e em formato de perguntas, a Segunda Circunscrição afirmou que o uso transformativo era de mínimo a inexistente.

${ }^{191}$ Trata-se de caso em que a autora tinha gravação exclusiva de espancamento de Reginald Denny, durante greves ocorridas em Los Angeles. A ré, sem autorização, colocou no ar um segmento da gravação, mas incorporando seu próprio relato oral do fato. A Nona Circunscrição por entender que a ré não havia acrescentado nada novo ou transformativo à gravação feita pelo autor, entendeu não haver uso justo.

192 ASCENSÃO, José de Oliveira. O fair use no direito autoral, p. 77.
} 
primígena estiver indisponível ou esgotada: haverá necessidade de acesso pelo público e o fair use será mais facilmente reconhecido.

Já o terceiro critério do fair use leva em consideração a quantidade e a qualidade da parte da obra originária aproveitada na nova criação, verificando-se se a utilização foi moderada ou não. A extensão da criação primígena utilizada na nova obra é analisada levando-se em conta a necessidade que o autor desta tinha de fazer uso daquela. Se o autor se valeu mais do que o estritamente necessário, seu uso não será considerado justo. Marshall Leaffer cita o exemplo de crítico literário que, ao avaliar o estilo de um autor, não poderá citar duas páginas se apenas dois parágrafos bastem para alicerçar os argumentos inseridos na crítica ${ }^{193}$.

Questão importante a ser considerada é que o terceiro fator, além da quantidade, leva em conta a qualidade da parte da obra primígena utilizada na obra nova. Assim, a utilização de pequeno trecho da obra anterior pode ser considerada injusta se tratar exatamente da essência da obra copiada. Porém, a Seção 107 não traz em seu bojo critérios que deveriam ser utilizados para se entender se a quantidade e substancialidade da parte da obra utilizada foi suficiente ou não, deixando tal tarefa aos Tribunais, que, devido à inexistência de critérios objetivos, podem vir a decidir de modo diferente para casos semelhantes.

$\mathrm{O}$ quarto fator, considerado pela jurisprudência norte-americana como o mais importante, se dá pela análise do efeito causado pela obra derivada no mercado da criação primígena, ou seja, verifica-se se a nova obra pode acabar substituindo a obra anterior no mercado. Segundo Eduardo Lycurgo Leite, "por esse fator um uso que não tenha qualquer efeito sobre o mercado ou valor potencial da obra deve ser permitido e não representará qualquer risco para a proteção autoral e o incentivo à criação"194.

Há evidente relação com o primeiro critério, pois há presunção de prejuízo à obra primígena se a nova obra foi criada com objetivo de lucro. A ameaça à obra primígena é maior quando a obra nova tende a diminuir suas vendas potenciais, ou interfere em sua negociabilidade ou até mesmo tende a preencher a demanda pelo original.

\footnotetext{
${ }^{193}$ LEAFFER, Marshall. Understanding copyright law, p. 327.

${ }^{194}$ LEITE, Eduardo Lycurgo. A doutrina do "fair use" delineada no direito autoral norte-americano, p. 129.
} 
Há quem entenda que a doutrina do fair use somente deveria ser aplicada quando houvesse insuficiência de mercado (market failure). É o que Eduardo Lycurgo Leite trata como teoria econômica do fair use $e^{195}$.

Seção II. O fair use e a paródia

É na paródia que o fair use parece ser mais importante. Conforme ensina José Mauro Gnaspini, “em geral, a mais imediata aplicação de seus preceitos se dá para a caracterização da liberdade paródica, garantindo a liberdade de crítica bem humorada e ácida, mesmo que se valha de trechos e cópias da obra do artista alvo da chacota"196.

Com relação à paródia, a primeira ação envolvendo o fair use julgada pela Suprema Corte norte-americana se deu no caso Campbell v. Acuff-Rose Music, Inc. Na verdade, o primeiro caso a chegar à Suprema Corte foi o caso Loew's Inc. v. Columbia Broadcasting System Inc. ${ }^{197}$, no qual houve divisão entre os juízes (4 a 4, pois um dos nove juízes não participou da decisão), não havendo, portanto, definição quanto ao fato de paródias estarem acobertadas pelo manto do fair use.

O autor Acuff-Rose Music Inc. processou um grupo de rap, 2 Live Crew, por ter infringido seu direito de copyright da música Oh, Pretty Woman, da autoria de Roy Orbison e William Dee. Os réus fizeram uma paródia intitulada Pretty Woman na qual substituiu-se a letra expressões fortes como "grande mulher peluda" e "mulher infiel".

\footnotetext{
${ }^{195}$ LEITE, Eduardo Lycurgo. A doutrina do "fair use" delineada no direito autoral norte-americano, p. 101104.

${ }^{196}$ GNASPINI, José Mauro. Derivação não consentida e proteção ao acréscimo criativo no direito de autor, p. 70 .

${ }^{197}$ Neste caso, conforme narra Judith B. Prowda (Parody and fair use in Copyright Law: setting a fairer standard in Campbell v. Acuff-Rose Music, Inc., p. 67-68), o comediante Jack Benny fez uma paródia do filme dramático Gaslight, intitulada Autolight, que seguia a linha da história original, embora acrescentasse piadas, mímicas e distorções para causar efeito cômico. A paródia era uma comédia para televisão, com enredo, diálogos e caracterização semelhantes, mas variando do original (por exemplo, os atores andavam sobre suas mãos). A Corte Distrital da Califórnia pareceu dar ao fair use a idéia de que o que é tomado da obra anterior não pode ser substancial e o que o uso dado à obra nova deve ser acadêmico e não comercial. A Corte de Apelação decidiu que a paródia constituía um uso substancial que não deveria ser tratado de modo diferente do que qualquer outra apropriação. A Corte enfatizou a motivação financeira do parodista: a paródia, nesse caso, tinha valor comercial e o fato de competir com a obra protegida pelo copyright ou ter sido feita para uso comercial eram fatores que pesavam na determinação do fair use e na determinação de ser substancial ou não o que fora utilizado da obra parodiada.
} 
Antes de lançarem a paródia, os réus entraram em contato com os autores para conseguirem a autorização para o uso, que lhes foi negada. Ainda assim, houve o lançamento da obra, dando os créditos a Orbison e Dees como autores da criação original. A Corte Distrital decidiu que a gravação era uma paródia e, portanto, se tratava de um uso justo do material protegido pelo copyright. Entendeu, ainda, que a paródia não usou mais do que o necessário da obra original e que dificilmente atingiria o mercado do original.

A Sexta Circunscrição reverteu o resultado do julgamento, entendendo não ter havido fair use, pois se a obra tinha objetivo comercial, a exploração indevida da obra original restava presumida. Assim, o caso não passaria pelo crivo do primeiro critério do fair use.

A Suprema Corte decidiu que os fatores do fair use eram apenas um guia geral para se determinar quais usos de obras preexistentes poderiam ser considerados justos. Apesar de ter analisado os quatro fatores, foi dado ênfase ao primeiro e ao quarto.

Ao debruçar-se sobre o primeiro critério, a Suprema Corte entendeu que o fato de uma paródia ser criada com finalidade comercial não gera presunção de que o uso não é justo. Foi levada em consideração, também, a idéia de uso transformativo.A decisão também conferiu relevância para o objetivo da paródia, decidindo que estará configurado o fair use se ela, ao menos em parte, fizer uma crítica à obra originária.

Quanto ao segundo fator, ficou entendido que ele não é de grande relevância para os casos envolvendo paródias, já que elas usam trabalhos publicamente conhecidos.

Versando sobre o terceiro critério, a Suprema Corte ponderou que é necessário verificar não apenas a extensão da cópia da obra anterior, mas, também, se a parte utilizada é o ponto central da criação primígena. Ficou entendido que se os réus tivessem imitado outra parte menos significativa para a identificação da criação parodiada talvez esse objetivo não fosse atingido.

Com relação ao quarto fator, por ser a paródia um uso transformativo, é mais provável que ela não afete o mercado da obra original, pois, como ambas são muito diferentes, cada uma atingirá parcela distinta do público. 
O caso Campbell v. Acuff-Rose Music, Inc., tem sido um parâmetro de julgamento para os tribunais norte-americanos, que levam em consideração vários aspectos para admitir que uma paródia esteja resguardada pelo fair use: a) a interdependência entre o primeiro e o quarto fator; b) a natureza transformativa da paródia; c) a necessidade de que, para que se reconheça a existência de paródia, esta vise, de algum modo, à crítica da obra preexistente; d) a constatação de que nova obra não substituirá a anterior no mercado consumidor e e) a finalidade comercial da paródia não implica presunção de que não se trata de fair use.

Conforme lição de Marshall Leaffer, como o titular do copyright da obra preexistente dificilmente autorizará uma utilização apta a ridicularizar a sua criação intelectual, é exatamente através da alegação de fair use que o parodista poderá defenderse e viabilizar juridicamente a sua obra ${ }^{198}$.

Em uma comparação entre o fair use e as limitações ao direito de autor previstas na lei brasileira, nota-se que a doutrina americana é mais ampla, pois não se limita a indicar hipóteses em que o uso é permitido, mas, sim, indica, de maneira geral, os critérios que o magistrado deverá seguir para identificar se o uso é justo ou não, ou seja, se há violação ou não ao direito de autor.

Nota-se, portanto, que o fair use, na realidade, embora conste na legislação norteamericana, continua tendo forte caráter jurisprudencial, pois é dada significativa liberdade para o juiz decidir nesse assunto. Não há regras fixas e a construção jurisprudencial é feita caso a caso. Devido a isso, é possível encontrar-se soluções opostas para hipóteses semelhantes, visto que os critérios são amplos e vagos, não existindo padrão claro para se entender a abrangência dos quatro fatores, suas inter-relações, ou mesmo como eles deve ser sopesados.

${ }^{198}$ LEAFFER, Marshall. Understanding copyright law, p. 339. 


\section{CAPÍTULO 4. HUMORISMO, LIBERDADE DE EXPRESSÃO E CENSURA}

Ao longo desse trabalho, vem sendo mostrado que a atividade humorística é relevante para o ser humano. Além de ser prazeroso, o humor tem se revelado, ao longo da história, um importante meio de manifestação do pensamento, já que menos sujeito a represálias daqueles que se incomodam com a crítica. Assim, é uma atividade útil ao ser humano, merecendo um tratamento diferenciado no aspecto jurídico.

O tratamento diferenciado acima referido, porém, não pode se revelar como um salvo-conduto ou uma absolvição prévia para exageros e prejuízos causados.

É sabido que não há direitos que não sofram atenuações. O próprio direito à vida que, segundo as palavras de Silmara Juny Chinellato ${ }^{199}$, é o direito condicionante, eis que sem ele os demais não existiriam, também recebe limitações, embora em situações extremas. Lembre-se que há previsão constitucional para a pena de morte em caso de guerra declarada ${ }^{200} \mathrm{e}$, em direito penal, se admite a ceifa da vida alheia em caso de legítima defesa ou estado de necessidade ${ }^{201}$. É claro que essas hipóteses concernem a situações de extrema gravidade, como um conflito armado que gere riscos à soberania nacional ou situações em que a conduta do agente visa à defesa de sua própria vida. É certo, porém, que, se o direito à vida fosse inatacável e não pudesse sofrer qualquer limitação, as hipóteses aqui tratadas não poderiam ser admitidas no direito pátrio.

Ora, se o direito mais importante de todos pode sofrer atenuações, conseqüentemente, todos os demais estarão sujeitos a serem afastados em prol de outros direitos que, na escala de valores na sociedade, ou ponderados em um caso concreto, mereçam prevalecer.

Assim, a liberdade de expressão também está sujeita a restrições. Analisando-se a atividade humorística surge, pois, uma questão: qual é o seu limite? Essa indagação não

\footnotetext{
${ }^{199}$ CHINELlATO, Silmara Juny. Arts. $1^{\circ}$ a 21, p. 18.

${ }^{200}$ Constituição Federal, artigo $5^{\circ}$, XLVII, letra $a$.

${ }^{201}$ Código Penal, artigos 24 e 25.
} 
tem resposta simples e imune a críticas. Entretanto, é importante empreender-se um esforço teórico para buscar a necessária resposta.

É reconhecida a importância do humor para o ser humano, o que justifica que a atividade humorística receba um tratamento mais condescendente pelo direito, viabilizando que, em algumas hipóteses, prevaleça no confronto com direitos de autor e da personalidade. Entretanto, se faz necessário admitir que muitos excessos são cometidos em seu nome, violando-se direitos autorais ou da personalidade. É preciso que a obra, para fazer jus a esse tratamento diferenciado, além de humorística, tenha um objetivo de crítica. A análise de três espécies de obras intelectuais esclarecerá melhor o que aqui se quer sustentar.

No concernente às paródias, é assente no direito de autor que elas devem ser imitações burlescas da obra parodiada. Assim, embora não seja dito expressamente, elas são admitidas como limitação do direito de autor da obra originária exatamente por serem humorísticas.

Dentro do acima exposto, pensando-se apenas em critérios de criatividade e originalidade, não haveria, em uma primeira análise, razão para, apenas em virtude do cunho humorístico, tornar as paródias livres, já que o autor de obra derivada que não se vale do objetivo humorístico também produz obra criativa e original. Conclui-se, portanto, que o direito de autor se afasta de um critério lógico e admite como paródia apenas a criação humorística, deixando de lado a obra que tenha por objeto o suspense ou o terror, por exemplo. A explicação para esse tratamento diferenciado está no fato de o direito de autor conferir tratamento privilegiado à atividade humorística, eis que esta é agradável e útil ao ser humano.

Não é, porém, apenas o objetivo humorístico que torna livres as paródias. É necessário, também, que essas criações apresentem uma finalidade de crítica à obra originária, ou seja, a ridicularização deve ser feita tendo como alvo a própria criação parodiada, e não elementos externos a ela, como outras obras intelectuais, pessoas ou fatos que não lhe digam respeito. Deve ser limite ao direito de autor somente a chamada paródiaalvo, na qual o parodista utiliza a forma antitética e humorística para criticar a obra primígena, mostrando o quanto ela pode ter de risível. Assim, a paródia que apenas busque 
criticar elementos externos à obra parodiada, o que se chama de paródia-arma, não deve ser considerada protegida no âmbito autoral, caso não haja autorização do autor da criação pimígena.

Já no concernente às caricaturas que, frise-se, em termos artísticos, não precisam ser necessariamente humorísticas, o conflito que existe não é o de direito autoral de dois criadores, como ocorre na paródia, mas, sim, o choque de interesses entre o direito de autor do caricaturista e o direito de personalidade do retratado.

Nesse caso, o argumento de que as caricaturas são livres simplesmente por serem humorísticas é frágil juridicamente. Não há razão para afastar-se o direito de imagem do retratado, privilegiando-se o direito do caricaturista. Ora, a caricatura, por definição, é o retrato humorístico de uma pessoa conhecida ou não, expresso de forma gráfica ou plástica, caracterizado pela deformação intencional da imagem do retratado; logo, deve-se notar que um de seus elementos, possivelmente o principal, é a deformação intencional da imagem do caricaturado, o que obviamente pode lhe desagradar. Dessa forma, não é adequado que se privilegie o objetivo do autor, em detrimento do direito à imagem da pessoa retratada de forma intencionalmente distorcida. Ressalte-se que a caricatura não tem qualquer cunho de crítica ou pertinência com a atividade do caricaturado; apenas há o humor por si só e, já que essa obra humorística fere direitos da personalidade, não pode existir sem a autorização do retratado.

O que é livre, na realidade, é a charge, que é o desenho que tem como objetivo, utilizando-se da via humorística, criticar fatos determinados. Nessa modalidade de humor gráfico, não existe a intenção cômica como um fim, mas, sim, como um meio para melhor alcançar o resultado de expressão de opinião sobre fatos específicos.

A charge é aqui lembrada porque nela o objetivo de crítica está presente e é mais facilmente perceptível, pois ela costuma se referir a fatos presentes no noticiário. Não é raro que ela acompanhe a própria notícia ou os respectivos comentários, demonstrando a opinião que o chargista tem sobre a notícia divulgada.

A charge jornalística, dessa forma, não se limita a fazer humor, mas, também, tem importante papel de exercício do direito de crítica e de liberdade de expressão com 
interesse público. A crítica, vinda das mãos do chargista, mesmo que muito intensa, se torna mais palatável em razão do efeito humorístico, sendo mais fácil de ser encarada a realidade.

Mostrados os exemplos das paródias, caricaturas e charges restou defendido que: a) somente a paródia-alvo é livre, já que é uma recriação humorística da obra com intuito de criticá-la; b) as caricaturas não são livres, dependendo da autorização das pessoas retratadas já que, na colisão entre direito de autor e direito à imagem, este deve prevalecer e c) as charges são livres, mesmo que reproduzam imagens de pessoas, eis que não têm o humor como um fim em si mesmo, mas, sim, o objetivo de crítica; logo, elas não dependem de autorização das pessoas nelas retratadas.

Dos três exemplos indicados, em dois (paródia-alvo e charge) a conclusão foi de que são livres, não dependendo de prévia autorização do autor da criação parodiada ou de eventuais pessoas retratadas na charge. Indaga-se: o que há de comum nessas duas modalidades de criações intelectuais que as tornam livres, o que não ocorre com as caricaturas?

Tanto a paródia-alvo como a charge, além do objetivo humorístico, apresentam uma finalidade de crítica, no primeiro caso às obras parodiadas e, no segundo, a fatos determinados. Em ambas, então, há dois elementos fundamentais, quais sejam, o humor e o direito de crítica. Já nas caricaturas existe apenas o efeito humorístico sem vir acompanhada de uma crítica.

O que pode gerar dúvidas sobre a possibilidade de definição de parâmetros para a licitude da atividade humorística quando esta entra em choque com direitos de autor ou da personalidade está no direito de liberdade de expressão e proibição de censura.

O humorismo tem respaldo tanto na liberdade de manifestação do pensamento, que é protegida no inciso IV, do artigo $5^{\circ}$, da Constituição Federal ("é livre a manifestação do pensamento, sendo vedado o anonimato"), como também no inciso IX, do citado artigo $5^{\circ}$, redigido nos seguintes termos: "IX - é livre a expressão da atividade intelectual, artística, científica e de comunicação, independentemente de censura ou licença". 
Também o artigo 220 da Constituição merece ser reproduzido:

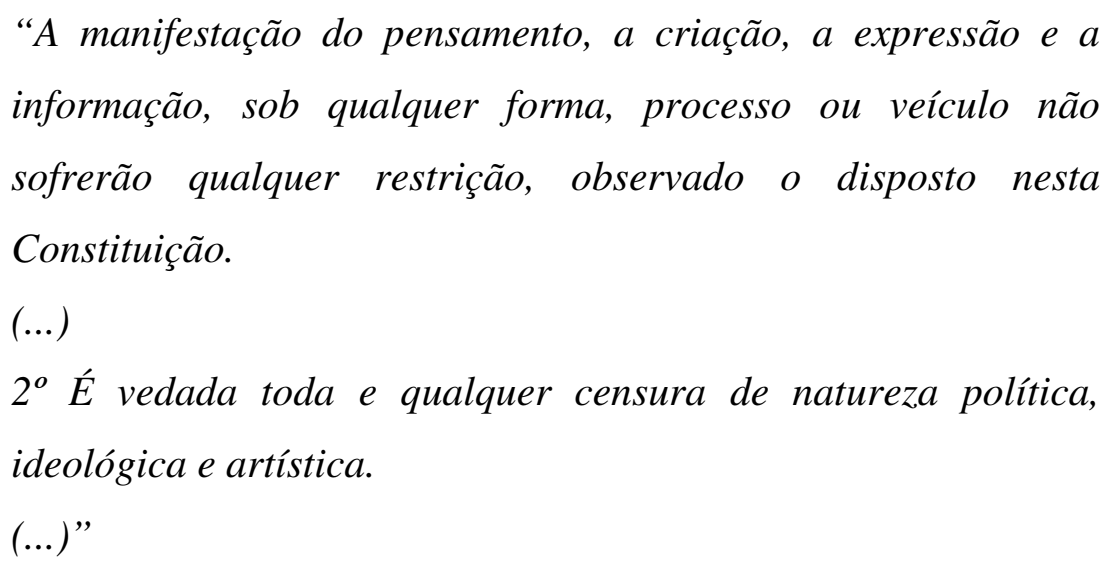

Uma primeira análise do texto constitucional poderia levar à conclusão de que o humorismo, como forma de expressão que é, seria intocável, absolutamente livre, estando acima de outros direitos. Após um estudo mais atento, porém, nota-se que essa idéia não é correta, pois há outros direitos que ocupam o mesmo patamar na Carta Magna, também sendo direitos fundamentais.

Há que se compreender o conceito de censura. Conforme a lição de Alexandre de Moraes,

a censura prévia significa o controle,o exame, a necessidade de permissão a que se submete, previamente e com caráter vinculativo, qualquer texto ou programa que pretende ser exibido ao público em geral. O caráter preventivo e vinculante é o traço marcante da censura prévia, sendo a restrição à livre manifestação de pensamento sua finalidade antidemocrática. ${ }^{202}$

No mesmo sentido, Luís Roberto Barroso explica que a "censura é a submissão à deliberação de outrem do conteúdo de uma manifestação do pensamento, como condição prévia de sua veiculação. Costuma ser associada a uma competência discricionária da Administração Pública, pautada por critérios de ordem política ou moral"203.

\footnotetext{
202 MORAES, Alexandre de. Direito constitucional, p. 52.

${ }^{203}$ BARROSO, Luiz Roberto. Liberdade de expressão, censura e controle da programação de televisão na constituição de 1988, p. 132.
} 
Resta claro que o que tipifica censura é a necessidade, para a divulgação do pensamento de uma pessoa, de uma análise prévia do conteúdo dessa manifestação, análise essa a ser feita por outrem, ficando seu autor à sua mercê.

A censura, de fato, não deve existir. Em um passado não muito distante, a história do Brasil foi manchada com esse tipo de prática estatal em que as artes, as atividades de imprensa e a manifestação política ficaram muito prejudicadas pela atuação de censores que tinham o poder de impedir a divulgação de obras intelectuais e informações que entendesse contrárias aos interesses do regime ditatorial existente.

Não é isso o que se pretende nesta pesquisa. A busca da conceituação das diversas atividades humorísticas e a esfera legal em que se inserem, tem como objetivo encontrar parâmetros para um bom convívio entre o humorismo e os direitos de autor das criações satirizadas, bem como a proteção dos direitos à imagem e honra das pessoas objeto de ridicularização. A finalidade não é acabar com a atividade humorística, mas, sim, fazer a ponderação de qual direito deve prevalecer quando há choque de interesses entre os humoristas e o satirizados.

Assim, da mesma forma que a liberdade de expressão é considerada um dos direitos fundamentais, o direito de autor e os direitos da personalidade também merecem o mesmo tratamento legal.

Não é demais lembrar, por exemplo, que a idéia de obra originária e obra derivada não é nova no Brasil e é bem aceita. Se a liberdade de expressão fosse levada a extremos, não poderia mais existir a distinção entre obras originárias e derivadas, eis que todas elas seriam manifestação da liberdade de criação.

Por outro lado, a liberdade de expressão não deve ser ilimitada a ponto de se tornar possível ao humorista a ofensa do direito à imagem das pessoas satirizadas pelo simples fato de ser manifestação criativa mesmo que desacompanhada de uma intenção de crítica e, conseqüentemente, de interesse público. No caso da ofensa à honra, a limitação do humorismo fica ainda mais clara, pois é muito difícil aventar uma hipótese de prática humorística que justifique a lesão à honra alheira. 
È por isso que a atividade humorística, mesmo que reconhecidamente importante para o ser humano, quando possa entrar em choque com direitos autorais ou da personalidade de outras pessoas, para ser permitida deve vir acompanhada de prévia autorização dos satirizados. No caso de o humorismo visar ao exercício do direito de crítica à obra ou à pessoa satirizada essa autorização não se torna necessária em razão do interesse público que existente. 


\section{PARTE 3 - CONCLUSÃO}

Após a pesquisa realizada sobre o tema da presente tese, é possível chegar-se a algumas conclusões:

1) A atividade humorística tem grande relevância para o ser humano, não apenas como lazer e entretenimento, mas também como instrumento de crítica e participação política, além de ser fator favorável ao bem-estar das pessoas, trazendo conseqüências benéficas no tratamento de doentes, possibilitando um melhor enfrentamento dos males corpóreos com a redução do sofrimento.

2) O direito à imagem não está apenas ligado à reprodução visual do corpo humano, tanto em seu todo como em suas partes separadas. Adota-se a distinção entre imagem-retrato e imagem-atributo, sendo esta o conjunto de características psicológicas ou morais com as quais a pessoa deseja ser vista pela sociedade, enquanto aquela é a representação visual do corpo humano, que pode se dar por diversos meios, como a fotografia, a pintura, o desenho, a caricatura, a escultura, a filmagem, e tantas outras formas de fixação e divulgação do aspecto corpóreo de alguém. 
3) $\mathrm{O}$ direito à voz é um dos direitos da personalidade. Por ser um forte elemento identificador da pessoa humana, eis que a voz, sozinha, pode ser suficiente para lançar na mente das demais pessoas a imagem de alguém. Imagem-retrato e direito à voz têm estreita relação, mas são distintos.

Além de estar constitucionalizado, o direito à voz está implicitamente assegurado no artigo 20 do Código Civil, quando este se refere à transmissão da palavra.

4) Apesar de a paródia, em sua natureza, não se limitar a uma imitação humorística de obra preexistente, no âmbito do direito de autor ela somente é admitida se tiver essa conotação cômica.

5) A paródia é obra derivada, já que, por sua própria natureza, é uma imitação de outra criação, partindo desta para, com efeitos de semelhança e dessemelhança, levar o público ao riso. Embora a intensidade da imitação seja variável em cada paródia, sempre está presente a transformação da obra primígena, característica da obra derivada. A própria dicção do artigo 47 da lei 9.610/98, que utiliza a palavra "originária”, reforça o entendimento de a paródia ser uma obra derivada.

6) Da leitura do artigo 47 da Lei $9.610 / 98$, não se extraem todos os requisitos para que uma obra seja considerada como paródia e, portanto, configure-se como uma das limitações do direito de autor. Da dicção legal resultam claros dois requisitos: a) imitação da obra primígena e b) não provocar descrédito à obra originária. Há, porém, outros que defluem da análise desse tipo de criação intelectual, pois aqueles expressos na lei são insuficientes para sua compreensão do que é a paródia. Assim, existem, também, os seguintes requisitos: a) objetivo humorístico, b) inconfundibilidade com a obra parodiada, c) ausência de prejuízo ao autor parodiado e d) finalidade de crítica à obra parodiada.

7) Somente deve ser considerada como paródia, para os efeitos do artigo 47 da Lei 9.610/98, a chamada "paródia-alvo", que é aquela que, se valendo da 
forma humorística, procura ser uma crítica à obra parodiada, sendo sua antítese. Por outro lado, a chamada "paródia-arma", que se configura pela imitação da criação primígena de forma humorística com a finalidade não de criticá-la, mas, sim, de atingir fatos ou pessoas estranhas à obra imitada, não pode ser verdadeiramente considerada paródia para os efeitos legais.

8) A restrição da aplicação do art. 47 da Lei 9.610/98 à paródia-alvo se justifica pelo direito de crítica que todos os autores podem ter em relação aos trabalhos de outros criadores. Essa crítica, desde que realizada de forma humorística, recebe proteção legal, já que o humor é importante forma de manifestação do pensamento. Já no caso da paródia-arma, não há razão para que uma obra originária seja livremente utilizada por terceiros apenas com a finalidade de crítica a outrem, e não à criação efetivamente imitada.

9) É relevante a distinção entre caricatura e charge. A caricatura, desde que dotada de criatividade e originalidade e seja exteriorizada, é criação artística protegida na esfera autoral. Ela se caracteriza pela reprodução da imagemretrato de uma pessoa, porém utilizando exageros e deformações. Ela tem apenas objetivos humorísticos, não se referindo a crítica política ou de fatos ou costumes, sendo, portanto, atemporal. Já a charge, que da mesma forma está protegida pelo direito de autor, caracteriza-se pela reprodução da imagem-retrato de uma pessoa com o objetivo de crítica a fatos específicos que a envolvam, ou seja, a fatos que mantenham alguma relação com o retratado. Neste caso, o humor é meio para que se atinja a finalidade que é a crítica com conteúdo atual. Assim, ela é temporal, referindo-se a fatos específicos.

10) Para que a caricatura seja lícita, deve vir acompanhada da autorização do caricaturado, já que se trata de reprodução distorcida e exagerada da imagem-retrato. A exigência de autorização justifica-se porque, como a caricatura visa apenas a fazer humor, não há interesse público que possa suplantar o direito à imagem-retrato do retratado. Por outro lado, a charge é livre, já que, como se utiliza o humor como instrumento para atingir um 
resultado maior, que é a crítica social e política, há interesse público em sua divulgação. Nesse caso, o direito de crítica, acompanhada de interesse público, merece restar em posição acima do direito à imagem-retrato da pessoa cujas características fenotípicas tenham sido reproduzidas.

11) A charge, para levar aos leitores a mensagem do autor, pode, eventualmente, utilizar a imagem de pessoas. A constatação da necessidade ou não da autorização do chargeado dependerá da avaliação dos conceitos de "alvo" e "arma'. Na charge-alvo, não há necessidade de autorização, já que o personagem reproduzido tem relação com o fato criticado pelo autor. Por outro lado, se o retratado for estranho em relação ao fato criticado, sua imagem terá sido divulgada sem razão lógica, sendo um mero instrumento para viabilizar ao chargista seu intento de crítica; esta é charge-arma que, em razão de sua natureza, depende da autorização do chargeado.

A charge pode conter caricatura, sem que isso a torne ilícita.

12) A imitação de pessoas pode se dar por meio visual ou sonoro. Em ambos os casos, a necessidade de autorização da pessoa imitada dependerá de ser a imitação "alvo" ou "arma". A imitação-alvo não exige autorização do imitado porque, no contexto em que ele é retratado, existe efetiva pertinência com a atividade ou atos por ele praticados. Já na imitação-arma haverá necessidade de consentimento do imitado, eis que o humorista aproveita a semelhança da voz ou da imagem do satirizado sem que haja conexão com o que é narrado, sendo, portanto, a referência ao imitado mero instrumento utilizado pelo humorista para alcançar seu intento.

13) No tocante a entrevistas humorísticas, como os entrevistados delas participam, é presumível que tenham dado autorização para divulgação das imagens e sons. Essa presunção, porém, é relativa, podendo os entrevistados fazerem prova de que não tinham ciência de que suas imagens ou voz seriam divulgadas. 
14) Embora seja presumível que nessas entrevistas tenha sido dado consentimento para a divulgação de imagens ou voz, isso não permite concluir que a este tenha precedido ampla informação do contexto da divulgação. Assim, para a divulgação das imagens ou da voz, deve existir o consentimento informado, isto é, precedido de amplo esclarecimento de que o entrevistado poderia ser colocado em situação humorística.

15) Quanto às câmeras escondidas, elas ofenderão o direito à imagem, caso as "vítimas" não tenham autorizado divulgação de suas imagens. Nesse caso, não há que se falar em consentimento informado, tendo em vista que, pela própria natureza desse tipo de atividade, quando a pessoa toma ciência de que participou de uma câmera escondida ela, a princípio, já sabe que a situação em que foi colocada é passível de riso. Assim, ao dar sua autorização, já tem ciência de que a situação pela qual passou é humorística.

16) As anedotas, desde que dotadas de criatividade e originalidade, estão dentro da esfera de proteção do direito autoral. Demonstrada a autoria, nada obsta a que seu criador tenha o pleno exercício de seus direitos patrimoniais ou morais.

17) Não se vislumbra nas anedotas potencial de ofensa à imagem das pessoas satirizadas. Ao contrário do que ocorre com outras atividades humorísticas, em que há efetiva utilização da imagem ou da voz dos retratados, ou, ao menos, aproximação a esses elementos individualizadores (o que ocorre nas hipóteses de imitação), as piadas fazem apenas referência a pessoas, o que é tênue.

18) As anedotas podem ofender a honra das pessoas satirizadas quando excedam os limites do bom senso.

19) A atividade humorística, quando em confronto com o direito à imagem e à voz, suscita diversas questões a serem ponderadas, já que estes direitos podem mais facilmente ser deixados de lado quando em confronto com o interesse público consubstanciado na liberdade de expressão e de crítica. 
20) Quando a atividade humorística atinge a honra das pessoas satirizadas, não se vislumbra possibilidade de essa ofensa ser legitimada por interesse público. A liberdade de expressão e o direito de crítica não podem ter o condão de permitir ofensa à honra. 


\section{BIBLIOGRAFIA}

ABRÃO, Eliane Yachouh. Direitos de autor e direitos conexos. São Paulo: Editora do Brasil, 2002.

ADOLFO, Luiz Gonzaga Silva. As limitações ao direito do autor na legislação autoral brasileira. Revista de direito autoral. Rio de Janeiro: Lumen Juris, Ano I, número II, p. 3$42,2005$.

ALBA, Isabel Espín. La parodia de obras divulgadas. In: Carlos Rogel Vide (Coord.). Los limites del derecho de autor. Madrid: Reus, 2006, p. 275-294.

ALVES, João Luiz. Código civil anotado. 3. ed. rev. e atual. por Ebert Chamoun, v. 3. Rio de Janeiro: Borsoi, 1958.

AMARANTE, Aparecida. Responsabilidade civil por dano à honra. 6. ed. Belo Horizonte: Del Rey, 2005.

ARAUJO, Luiz Alberto David. A proteção constitucional da própria imagem. Belo Horizonte: Del Rey, 1996.

O conteúdo do direito à própria imagem: um exercício de aplicação de critérios de efetivação constitucional. Revista do Advogado. São Paulo: Associação dos Advogados de São Paulo, Ano XXIII, número 73, p. 119-126, 2003.

ARIENZO, Alfredo. Paródia (verbete). In: Novísimo digesto italiano. Torinese, vol. XII, p. 448-449.

ARISTI, Rafael Sánchez. La propiedad intelectual sobre las obras musicales. $2^{\text {a }}$ edición revisada, actualizada y ampliada. Granada: Comares, 2005.

ASCENSÃO, José de Oliveira. Direito autoral. 2. ed., ref. e ampl. - Rio de Janeiro: Renovar, 1997. 
O fair use no direito autoral. Revista forense. Rio de Janeiro: Forense, ano 99, v. 365, p. 73-83, 2003.

BARROSO, Luís Roberto. Liberdade de expressão, censura e controle da programação de televisão na constituição de 1988. Revista dos tribunais. São Paulo: Revista dos Tribunais, Ano 90, v. 790, p. 129-152, 2001.

BELLEFONDS, Xavier Linant de. Droits d'auteur et droits voisins. Paris: Dalloz, 2002.

BERGSON, Henri. O riso: ensaio sobre a significação da comicidade. São Paulo: Martins Fontes, 2001.

BITTAR, Carlos Alberto.Direito de autor. 4. ed. rev., ampl. e atual. por Eduardo Carlos Bianca Bittar. Rio de Janeiro: Forense Universitária, 2008.

Os direitos da personalidade. 7. ed. atual. por Eduardo Carlos Bianca Bittar. Rio de Janeiro: Forense Universitária, 2008.

BORGES, Roxana Cardoso Brasileiro. Dos direitos da personalidade. In: Renan Lotufo; Giovanni Ettore Nanni (Coord.). Teoria geral do direito civil. São Paulo: Atlas, 2008, p. 242-280.

BREMMER, Jan. Piadas, comediógrafos e livros de piadas na cultura grega antiga. In: Jan Bremmer; Herman Roodenburg (Org.). Uma história cultura do humor. Trad. de Cynthia Azevedo e Paulo Soares. Rio de Janeiro: Record, 2000, p. 27-50.

BREMMER, Jan; ROODENBURG, Herman. Introdução: humor e história. In: (Org.). Uma história cultural do humor. Trad. de Cynthia Azevedo e Paulo Soares. Rio de Janeiro: Record, 2000, p. 13-25.

BREWER, Derek. Livros de piada em prosa predominantes na Inglaterra entre os séculos XVI e XVIII. In: Jan Bremmer; Herman Roodenburg (Org.). Uma história cultural do humor. Trad. de Cynthia Azevedo e Paulo Soares. Rio de Janeiro: Record, 2000, p. 133163. 
CARVAlHO, Carlos Eduardo Neves de. A doutrina do fair use nos EUA. Revista da associação brasileira de propriedade intelectual. São Paulo: ABPI, n. 77, p. 50-56, jul/ago, 2005.

CARVALHO SANTOS, J. M. Código civil brasileiro interpretado: principalmente do ponto de vista prático. 15. ed., v. VIII. Rio de Janeiro: Freitas Bastos, 1988.

CATANI, Afrânio Mendes; SOUZA, Inácio de Melo. A chanchada no cinema brasileiro. São Paulo: Brasiliense, 1983.

CHAVES, Antônio. Direito de autor: princípios fundamentais. v. I. Rio de Janeiro: Forense, 1987.

. Caricatura: protegibilidade. O Estado de São Paulo, São Paulo, 02 de agosto de 1989 , p. 21.

CHINELLATO, Silmara Juny. Arts. $1^{\circ}$ a 21. In: Antônio Cláudio da Costa Machado (Org.); Silmara Juny Chinellato (Coord.). Código civil interpretado: artigo por artigo, parágrafo por parágrafo. Barueri: Manole, 2008, p. 7-25.

CIFUENTES, Santos. Derechos personalísimos. $2^{\mathrm{a}}$ edición actualizada y ampliada. Buenos Aires: Astrea. 1995.

COLOMBET, Claude. Propriété littéraire et artistique. Troisième édition. Paris: Dalloz, 1986.

COSTA NETTO, José Carlos. Direito autoral no Brasil. 2. ed. rev., ampl. e atual. São Paulo: FTD, 2008.

DE CUPIS, Adriano. Os direitos de personalidade. 2. ed. Trad. de Afonso Celso Furtado Rezende. São Paulo: Quorum, 2008.

DESBOIS, Henri. Le droit d'auteur en France. Troisième édition. Paris: Dalloz, 1978. 
DINIZ, Maria Helena. Curso de direito civil brasileiro: teoria geral do direito civil. 24. ed. rev. e atual. São Paulo: Saraiva, 2007.

DORETTO, Fernanda Orsi Baltrunas. Direito à imagem. São Paulo, 2003. Dissertação (Mestrado em Direito) - Pós-Graduação em Direito da Universidade de São Paulo.

DUMAS, Roland. La propriété littéraire et artistique. Paris: Presses Universitaires de France, 1987.

DUVAL, Hermano. Direito à imagem. São Paulo: Saraiva, 1988.

FABIANI, Mario. La protezione giuridica della parodia con particolare riferimento a recenti orientamenti di giuristi stranieri. Il diritto di autore. Milano: Giuffrè, Anno LVI, n. 4, p. 461-469, 1985.

FERREIRA, Aurélio Buarque de Holanda. Novo dicionário da língua portuguesa. 2. ed. rev. e aum. Rio de Janeiro: Nova Fronteira, 1986.

FONSECA, Joaquim da. Caricatura: a imagem gráfica do humor. Porto Alegre: Artes e Ofícios, 1999.

FRAGOLA, Augusto. Liceitá e limiti della parodia alla luce di recenti esperienze. Il diritto di autore. Milano: Giuffré, Anno LXXIII, n. 1, p. 372-378, 2002.

FRANÇA, Rubens Limongi. Manual de direito civil. 4. ed., rev. v. 1. São Paulo: Revista dos Tribunais, 1980.

Direitos da personalidade: coordenadas fundamentais. Revista dos Tribunais. São Paulo: Revista dos Tribunais, ano 72, v. 567, p. 09-16, 1983.

FRANÇON, André. Questions de droit d'auteur relatives aux parodies et productions similaires. Le droit d'auteur. 101e année, n. 6, p. 302-306, juin, 1988. 
GAGLIANO, Pablo Stolze; PAMPLONA FILHO, Rodolfo. Novo curso de direito civil: parte geral. 8. ed. rev., atual. e reform. São Paulo: Saraiva, 2006.

GAUTIER, Pierre-Yves. Propriété littéraire et artistique. 4e. édition mise à jour. Paris: Presses Universitaires de France, 2001.

GARCIA, Enéas Costa. Responsabilidade civil nos meios de comunicação. São Paulo: Juarez de Oliveira, 2002.

GNASPINI, José Mauro. Derivação não consentida e proteção ao acréscimo criativo no direito de autor. São Paulo, 2008. Tese (Doutorado em Direito) - Pós-Graduação em Direito da Universidade de São Paulo.

GODOY, Claudio Luiz Bueno de. A liberdade de imprensa e os direitos da personalidade. São Paulo: Atlas, 2001.

GONÇALVES, Carlos Roberto. Direito civil brasileiro: parte geral. 2. ed. rev. e atual. São Paulo: Saraiva, 2005.

HENFIL. Como se faz humor político. (entrevista concedida a Tárik de Souza) 2. ed. Rio de Janeiro: Vozes, 1985.

HOUAISS, Antônio; VILlAR, Mauro de Salles. Dicionário Houaiss da língua portuguesa. Rio de Janeiro: Objetiva, 2001.

JARACH, Giorgio. Manuale del diritto d'autore. Milano: Mursia, 1991.

KOZINSKI, Alex. What's so fair about fair use? Journal of the Copyright Society of the USA. New York, vol. 46, n. 4, p. 513-530, summer 1999.

LANDES, William M.; POSNER, Richard A. La estructura económica del derecho de propiedad intelectual e industrial. Traducción de Victor Manuel Sánchez Alvarez. Madrid: Fundación Cultural del Notariado, 2006. 
LEAFFER, Marshall A. Understanding copyright law. Second edition. New York: Matthew Bender, 1995.

LEITE, Eduardo Licurgo. A doutrina do "fair use" delineada no direito autoral norteamericano: uma ferramenta para o ponto de equilíbrio entre a rigidez autoral e o interesse público relevante. Revista de direito autoral. Rio de Janeiro: Lumen Juris, Ano II, n. IV, p. 75-134, 2006.

LEITE, Sylvia Helena Telarolli de Almeida. Chapéus de palha, panamás, plumas, cartolas: a caricatura na literatura paulista (1900-1920). São Paulo: Fundação Editora da UNESP, 1996.

LIPSZYC, Delia. Derecho de autor y derechos conexos. Reimpresión inalterada de la edición de 1993. Buenos Aires: UNESCO/CERLALC/ZAVALIA, 2005.

LUCAS, A.; LUCAS, H. J. Traité de la proprieté littéraire \& artistique. Paris: Litec, 1994.

MANSO, Eduardo Vieira. Direito autoral: exceções impostas aos direitos autorais (derrogações e limitações). São Paulo: Bushatsky, 1980.

MEIRELLES, William Reis. Paródia e chanchada: imagens do Brasil na cultura das classes populares. Londrina: Eduel, 2005.

MENDO, Anselmo Gimenez. História em quadrinhos: impresso vs. web. São Paulo: UNESP, 2008.

MENEZES, Elisângela Dias. Curso de direito autoral. Belo Horizonte: Del Rey, 2007.

MOISÉS, Massaud. Dicionário de termos literários. 2. ed. São Paulo: Cultrix, 1978.

MORAES, Alexandre de. Direito constitucional. 23. ed. São Paulo: Atlas, 2008. 
MORATO, Antonio Carlos. Direito à voz: reflexões sobre sua proteção no âmbito da sociedade da informação. In: Liliana Minardi Paesani (Coord.). O direito na sociedade da informação. São Paulo: Atlas, 2007, p. 159-175.

MOURA, Wagner. Meleca no ator. $O$ globo, Rio de Janeiro, 29 de maio de 2008.

MUNTAÑOLA. Mario Sol. El régimen jurídico de la parodia. Madrid: Marcial Pons, 2005 .

NAÏR, Sami. Libertad y sagrado: el caso de lãs viñetas. In : (ed.) Democracia y responsabilidade: las caricaturas de Mahoma y la libertad de expresión. Barcelona: Galaxia Gutemberg, 2008, p. 33-44.

OLIVEIRA, Jaury Nepomuceno de; WILLINGTON, João. Anotações à lei do direito autoral: lei no. 9.610/98. Rio de Janeiro: Lumen Juris, 2005.

PARILLI, Ricardo Antequera. La obra como objecto del derecho de autor. In: Bruno Jorge Hammes (Org.) Seminário internacional sobre direitos autorais (Anais). São Leopoldo: Unisinos, 1994, p. 41-71.

POLLOCK, Jonathan. Que es el humor? Traducción de Alcira Bixio. Buenos Aires: Paidós, 2003.

PONTES DE MIRANDA, Francisco Cavalcanti. Tratado de direito privado. Tomo VII. Rio de Janeiro: Borsoi, 1955.

PROWDA, Judith B. Parody and fair use in copyright law: setting a fairer standard in Campbell v. Acuff-Rose Music, Inc. Communications and the law. Littleton: Fred B. Rothman \&Co., n. 3, v. 17, september 1995.

PUEO, Juan Carlos. Los reflexos en juego: una teoria de la parodia. Valencia: Tirant lo Blanch, 2002. 
RAMOS, Paulo Eduardo. Tiras cômicas: duas leituras, um efeito de humor. São Paulo, 2007. Tese (Doutorado em Letras) - Pós-graduação em Letras da Universidade de São Paulo.

RIANI, Camilo. Linguagem \& cartum...tá rindo do quê?: um mergulho nos salões de humor de Piracicaba. Piracicaba: UNIMEP, 2002.

RODRÍGUEZ-CANO, Rodrigo Bercovitz. La obra (títulos 1 a 7, 9 e 12 a 15). In: (Coord). Manual de propiedad intelectual. $3^{\mathrm{a}}$ edición. Valencia: Tirant lo Blanch, 2006.

ROMUALDO, Edson Carlos. Charge jornalística: intertextualidade e polifonia: um estudo de charges da Folha de S. Paulo. Maringá: Eduem, 2000.

RUI, Jota. A alegre história do humor no Brasil. Rio de Janeiro: Expressão e Cultura, 1979.

SADOCK, Benjamin James; SADOCK, Virginia Alcott. Compêndio de psiquiatria: ciências do comportamento e psiquiatria clínica. 9. ed. Trad. de Claudia Oliveira Dornelles, Cristina Monteiro, Irineo S. Ortiz e Ronaldo Costa Cataldo. Porto Alegre: Artmed, 2007.

SAHM, Regina. Direito à imagem no direito civil contemporâneo: de acordo com o novo Código Civil, Lei n. 10.406, de 10-1-2002. São Paulo: Atlas, 2002.

SANT'ANNA, Affonso Romano de. Paródia, paráfrase \& cia. 7. ed. $5^{\text {a }}$ impressão. São Paulo: Ática, 2003.

SANTOS, Newton Paulo Teixeira dos. Paráfrase, paródia e direito autoral. Atualidades Forenses, v. 12, n. 117, p. 08-11, 1988.

SILVEIRA, Newton. Propriedade intelectual: propriedade industrial, direito de autor, software, cultivares. 3. ed. rev. e ampl. Barueri: Manole, 2005.

SIRINELLI, Pierre. Propriété littéraire et artistique. 2e. édition. Paris: Dalloz, 2003. 
TARNEC, Alain Le. Manuel de la proprieté litteraire et artistique. 2e. édition. Paris: Dalloz, 1966.

VENOSA, Sílvio de Salvo. Direito civil: parte geral. 8. ed. São Paulo: Atlas, 2008.

VERÍSSIMO, Luis Fernando. Charge não ofende (entrevista concedida a Francisco Alves

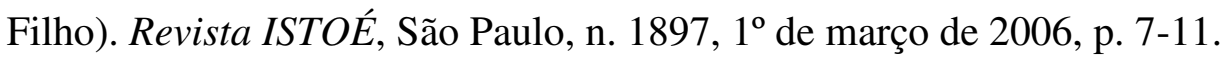

VIDE, Carlos Rogel. Derecho de autor. Barcelona: Cálamo, 2001.

ZIMMERMAN, Diane Leenheer. The more things change, the less they seem "transformed": some reflections on fair use. Journal of the Copyright Society of the USA. New York, vol. 46, n. 2, p. 53-93, winter 1998. 
ANJOS, Marco Antonio dos. O humor: estudo à luz do direito de autor e da personalidade. Tese (Doutorado) apresentada na Faculdade de Direito da Universidade de São Paulo, 2009.

\section{RESUMO}

A presente Tese teve como objetivo estudar o humor e suas repercussões no âmbito do direito de autor e da personalidade, buscando especificar critérios para melhor conceituação de várias formas de atividades humorísticas e, também, para, quando estas entram em choque com o direito de autor e da personalidade, encontrar as soluções mais adequadas de quais direitos devem prevalecer.

A pesquisa tem início com um breve estudo sobre o humor, abordando a dificuldade de sua conceituação, já que não há padrões exatos para a identificação das atividades que provocam o riso nas pessoas.

Em seguida, algumas formas de expressão humorística, que são comumente encontradas no dia-a-dia, foram especificadas e conceituadas. É o caso da paródia, do pastiche, da caricatura, da charge, do cartum, dos quadrinhos e das anedotas. As distinções entre as manifestações humorísticas foram destacadas, pois, dependendo de suas características, um tipo de humor pode ser permitido pelo direito, sem que haja necessidade de autorização do criador da obra primígena ou do titular de direitos da personalidade.

A importância do humor para os seres humanos foi realçada, reconhecendo-se que se trata de uma atividade que tem valor, como provam a sua influência como manifestação política e, ainda, o seu uso no auxílio ao tratamento de doenças e à redução de seus males.

Após uma visão geral do humor, com suas particularidades e benefícios, esta pesquisa se concentrou na análise das repercussões jurídicas da expressão humorística no que concerne ao direito de autor (enquanto limitação a este) e da personalidade (e seu possível choque com os direitos à imagem e à honra).

Na seqüência, o trabalho tratou das conseqüências jurídicas de certas manifestações humorísticas e das ofensas que podem causar ao direito de autor ou aos direitos da personalidade: paródias, caricaturas, charges, imitações cômicas, entrevistas humorísticas, câmeras escondidas e anedotas. Para isso, buscou-se auxílio tanto na legislação, como na doutrina e na jurisprudência.

O principal objetivo da Tese foi trazer parâmetros para melhor classificação das formas de expressão humorística, já que se constata que ainda existe certa insegurança na análise das repercussões jurídicas do humor quando este pode ferir direito de autor ou direitos da personalidade.

Palavras-chave: direito de autor; direito da personalidade; humor; paródia; caricatura. 
ANJOS, Marco Antonio dos. Humor: study under the copyright law and the civil rights. Thesis (Doctor Degree) presented at São Paulo University Law School, 2009.

\begin{abstract}
This Thesis had the purpose of studying humor and its repercussion regarding copyright law and civil rights, trying to establish criteria to improve the conception of various humoristic activities and also find the adequate solution of which right should prevail when these activities are confronted to copyright law and civil rights.

The research starts with a brief analysis of humor, showing the difficulty in defining it, since there are no exact standards to identify the activities that can make people laugh.

After, some commonly found humoristic forms of expression were specified and defined, like parodies, pastiche, caricatures, political cartoons, cartoons, comics and jokes. The distinctions among these humoristic forms were enhanced because, depending on their characteristics, kinds of humoristic expression can be allowed without the necessity of the authorization from the author of the original work or from the holder of the civil rights.

The relevance of humor for the human being was highlighted, recognizing it as an important activity, proved by its influence in political manifestations and, also, its use in the treatment of diseases and in the reduction of their consequences.

After a general view of humor and its particularities and benefits, this research focused in the analysis of the legal repercussions of humoristic expressions regarding copyright law (as a limit for it) and civil rights (and its possible confrontation with the right of publicity and the right to honor and dignity).

Next, this Thesis studied the legal consequences of certain humoristic manifestations and the offenses they can cause to copyright law or to civil rights: parodies, caricatures, political cartoons, comic imitations, humoristic interviews, hidden cameras and jokes. For that, legislation, doctrine and jurisprudence were analyzed.

The main purpose of the Thesis was to give parameters for a better classification of the different forms of humoristic expression, since there is some insecurity in the analysis of the legal repercussions of humor when it can harm copyright law or civil rights.
\end{abstract}

Key words: copyright law; civil rights; humor; parody; caricature. 
ANJOS, Marco Antonio dos. L'humour: étude sous la lumière du droit d'auteur et de la personnalité. Thèse (Doctorat) présentéé dans la Faculte du Droit du la Université du São Paulo, 2009.

\section{RÈSUMÉ}

Cette Thèse a eu comme objectif étudier l'humour et leurs répercussions dans le contexte du droit d'auteur et de la personnalité, en cherchant de spécifier des critères pour meilleure conceptualisation de plusieurs formes d'activités humoristiques et, aussi, pour, quand celles-ci entrent dans choc avec le droit d'auteur et de la personnalité, trouver les solutions les plus appropriées de quels droits doivent prévaloir.

Ce travail commence avec um bref étude sur l'humour, en s'abordant la difficulté de sa conceptualisation, car il n'y a pas de normes exactes pour l'identification des activités qui provoquent le rire dans les personnes.

Ensuite, quelques formes d'expression humorística, qui fréquemment sont trouvées dans le quotidien, ont été spécifiées et évaluées. C'est le cas de la parodie, du pastiche, de la caricature, de la charge, du cartoon, des bandes dessinées et des anecdotes. Les distinctions entre les manifestations humoristiques ont été détachées, donc, en dépendant de leurs caractéristiques, un type d'humeur peut être permis par le droit, sans que il y ait nécessité d'autorisation pour le créateur de l'oeuvre originaire ou du titulaire de droits de la personnalité.

L'importance de l'humour pour les êtres humains a été soulignée, en se reconnaissant qu'il s'agit d'une activité qui a de la valeur, comme prouvent son influence comme manifestation politique et, encore, son utilisation dans l'aide au traitement de maladies et à la réduction de leurs maux.

Après une vision générale de l'humour, avec leurs particularités et bénéfices, cette recherche s'est concentrée sur l'analyse des répercussions juridiques de l'expression humorística en ce qui concerne le droit d'auteur (tant que limitation à celui-ci) et de la personnalité (et son possible choc avec les droits à l'image et à l'honneur).

Dans la sequence, le travail a traité des conséquences juridiques de certaines manifestations humoristiques et des infractions qui peuvent causer au droit d'auteur ou aux droits de la personnalité : parodies, caricatures, charges, imitations comiques, entrevues humoristiques, caméras cachées et anecdotes. Pour cela, se cherche aide tant dans la législation, que dans la doctrine et dans la jurisprudence

Le principal objectif de la Thèse a été apporter paramètres pour meilleur classement des formes d'expression humoristique, car existe certaine insécurité dans l'analyse des répercussions juridiques de l'humour quand celui-ci peut blesser droit d'auteur ou droits de la personnalité. 
Mots-clés: droit d'auteur; droit de la personnalité; humour; parodie: caricature. 